\title{
الجزء من
}

\section{القفو ائد المنتهّاة الـغر ائبـ}

انتخاب الثيخ أبي الحسن علي بن عمر الدارقطني

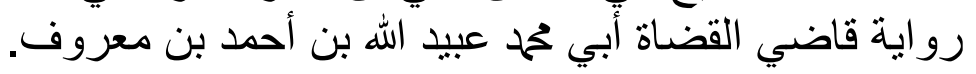

رواية أبي القاسهم عبد الكريم بن محمد بن عبيد الله السياري

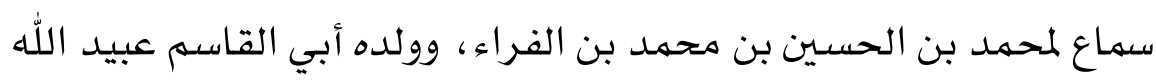

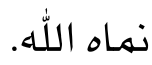

$$
\begin{aligned}
& \text { تحقيق وتخريج ودر اسة } \\
& \text { حققه وخرج أحاديثه ودرسها } \\
& \text { مازن بن حمح بن ححم بن حسانين }
\end{aligned}
$$

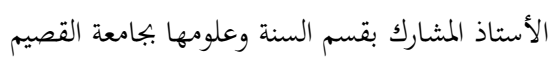

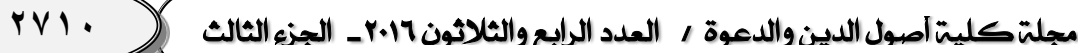




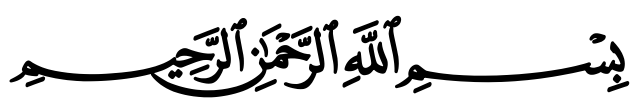

الحمد للهه والصـلاة والسـلام على رسول الله وبعد :

فقد بلفت عناية المحدثين بالحديث النبوي الغاية التي لا مزيد

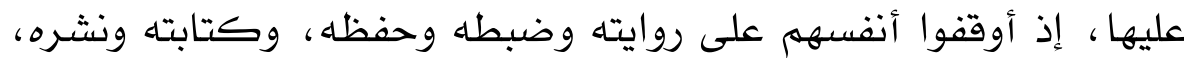
وهجروا الأهل والبلدان، وتركوا الصحب والخانلان، حتى جمعوا من روايته ما قرت باه أعينهم، وأنست به أنفسهم، وقد كان دوأبهم استيعاب أحاديث

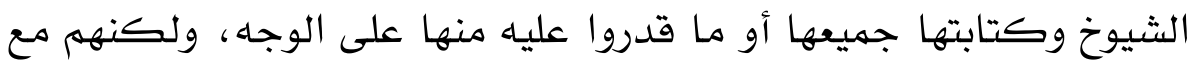

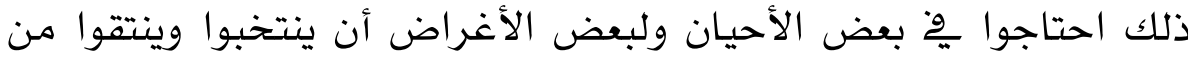

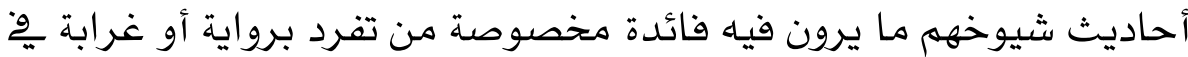
طريق أو متن، أو علو أو حسن أو غير ذلك، تارة لضيق الوقت وتعذر كتابة جميع حديث الشيخ وسماعاه، لا سيها وعامتاه مروي مسموع عندهم من

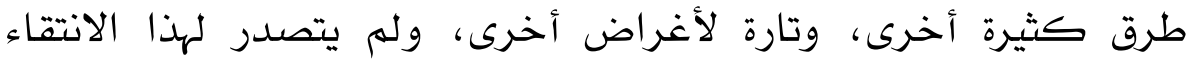

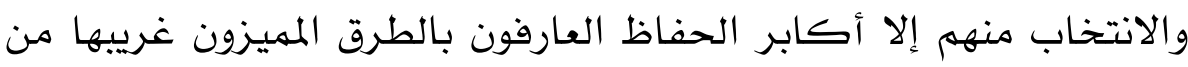

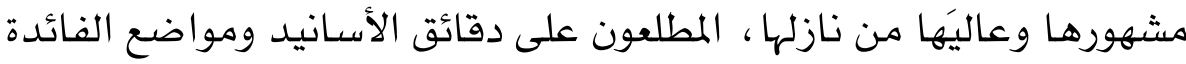
من الأحاديث.

ومن هؤلاء المتقنين القائمـين بأعباء هذه الصناعة الإمام الحافظ العلم العلامة أبو الحسن علي بن عمر الدارقطني البغدادي رضي الله عنه

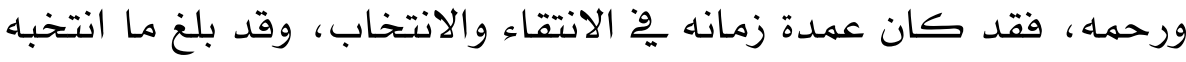
من حديث أبي بكر الثـافي وحده تمام المائة جزء، فكيف الظن بجميع

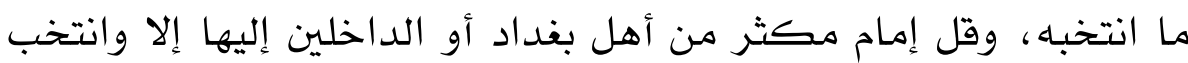
عليه الدارقطني.

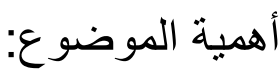

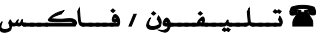


وهذا الجزء الذي عملت على تحقيقهاه ودراسته وتخريجه إنما هو

نهوذج يسير مها انتخبه الدراقطني من حديث القاضي ابن معروف، وقد انتخب الدارقطني من حديث ابن معروف عدة أجزاء هذا واحد منها وبين يدي جزء آخر من انتخاب الدارقطني لكنه وِّ الأحاديث الحسان، وتكهن أهمية جزئنا هذا وِّ كون كل أحاديثه غرائب الأسـانيد، وإن كان عامتها صحاحا مشاهير ثابتة من طرق أخرى بعضها (الصحيحين)" ، وهذا مها يصعب على غير الحافظ المطلع بيانه وانتقاؤه. ثم مها يزيده أهمية كونه بخط الإمام العلامة كبير الحنابلة

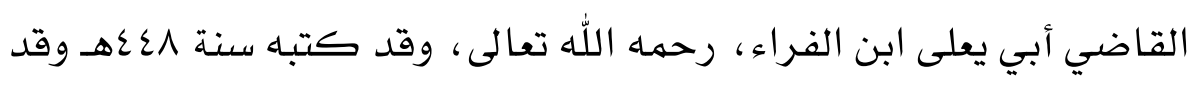
مضى على كتابته الآن نحو الألف عام، فهذه قيمة أخرى تضاف إلى قيمة موضوعاه ومنتخبـه.

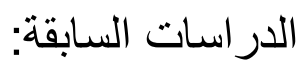

ولهم أقف على من اعتىى بهذا الجزء من قبل ولا بشيء من حديث ابن معروف عموما حسب علمي، بعد مراجعة مراكز البحوث والدراسات، وأهل الخبرة بهذا الثـأن، والله أعله. منهج البحث: - (1)

وقد اعتمدت فيه المنهج الوصفي يخ التعامل مع مخطوطته، ثم

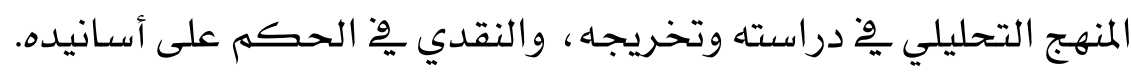
إجر اءات البحث: - و 
ا

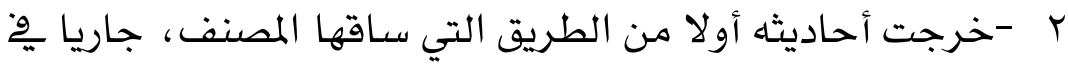
ذلك على طريقة المتابعات التامة فالقاصرة، محاولا الاستيعاب مِّْ ذلك ما وسعني ذلك وتيسر لي، مبينا وجه الفرابة وِ الطريق التي انتخبها الدارقطني. ثم أخرجها من طرقه المشهورة الأخرى بها يبين أن أصله مشهور

منتشر ، ولا أستقصي يوٌ سرد طرقه المشهورة لعدم الحاجة إلى ذلك هنا. r -ترجمت لجميع رجال هذا الجزء عدا الصحابة فلم أترجم لهم لاستفنائهم عن ذلك بشرف الصحبة، وكذا ترجمت لرواته عن المصنف، ورجال السماعات.

ع -قدمت بين يدياه بدراسة مختصرة عن الفوائد الحديثية والانتخاب، وترجمت فيها للقاضي ابن معروف، وللإمام الدارقطني، وعرجت فيها على عنايته بالانتخاب، ثم وصفت النسخة المعتمدة. 0 - -عملت لله الفهارس الخادمة.

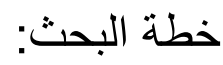
وقد جرى العمل من خلال مقدمة وقسـم للدراسـة وقسـم للتحقيق،

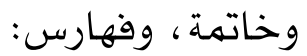

فأما المقدمة: فتتاولت فيها أهمية العهل، والدراسـات السابقة، والمنهج المعتهد يخّ البحث، وإجراءاته، وخطة العهل. و أما قسم الدر اسة: فاشتهل على المباحث التالية: 
المبحث الأول: الفو ائد تعريفها، وفائدتها.

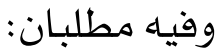

الإمالب الأول: تعريف الفوائد.

الأطلب الثٔاني: فوائد كتب ((الفوائد ).

المبحث الثاني: الانتخاب تعريفه، وأشهر أسبابه، وصفة المنتخب. وفيه ثلاثة مطالب:

الالمطاب الأول: تعريف الانتخاب.

الامطلب الثماذي: أشهر أسبابه.

الإطلب الثُالث: صفة المنتخب.

المبحث الثالث: ترجمة القاضي ابن معروف.

المبحث: الرابع: ترجمة مختصرة للإمام الدراقطني وفيها بيان

عنايته بالانتخاب. وفيه مطلبان:

الإطلب الأول: ترجمة الدارقطني. الاطلب الثاذبي: عنايته بالانتخاب. المبحث الخامس: التعريف بالجزء ووصف النسخة الخطية، وترجمة رو اتها. وفيه مطلبان:

الإطلب الأول: التعريف بالجزء.

الإطلب الثُاني: وصف النسخة الخطية وترجمة رواتها.

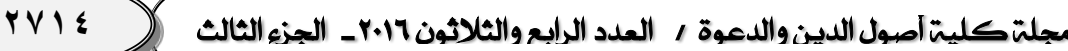


و أما قسم التحقيق: فقيه النص المحقق مخرجا مدروسـا. ثم الخاتمة، وفيها أهم النتائج و التوصيات. و أخيرا الفهارس، وتتشتهل على ( فهرس الآيات، والأحاديث، والرواة، والمصادر والمراجع، والموضوعات).

وأخيرا فهذا جهد المقل، فإن يكن صوابا فهن الله والحمد له، وإن تكن الأخرى فذنوب ركبتا وعجل الله لنا عقوبتها يوخ قلة التوفيق وسوء الصنعة، وأسال الله أن يتجاوز عنا بلطفه وكرمها، وقل وري رب اغفر وارحمى وأنت خير الراحمـين.

وصلى الله على سيدنا محمد وسلهم تسليما كثيرا

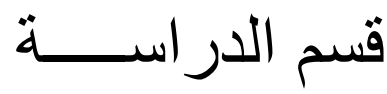

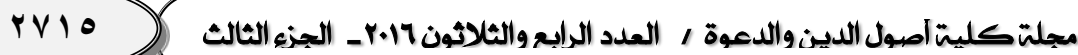




\section{المبحث الأول: الفو ائد تعريفها، وفائدتها' '). المطلب الأول: تعريف الفوائد}

الفوائد لغة: جمع فائدة، والفائدة هي كل ما يستقاد، قال الجوهري يُّ (الصحاح)) : (الفائدة: ما استقدت من علم أو مال)"(؟). وقال ابن منظور پِّ: (السـان العرب)): (الفائدة: ما أفاد الله تعالى العبد من خير يستفيده، ويستحدثه، وجمعها : الفوائد)، ، ونقل عن النضر بن شميل قوله: "ايقال: إنّهما ليتفايدان بالمال بينهما أي: يفيد كلّ واحد منهما صاحبه،

والنّاس يقولون: هما يتفاودان العلم، أي: يفيد كلّ واحد منهما الآخر)|"(r). وأما في الاصطلاح: فلم يشتهر لها ما يهكن أن يسهى تعريفا بالمعنى الاصطلاحي، فليست نوعا مستقلا من أنواع علوم الحديث التي

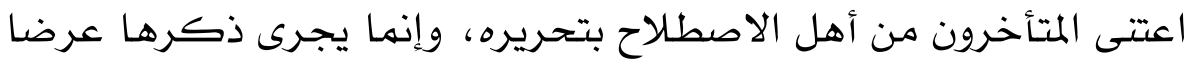

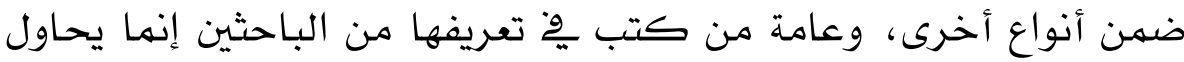
تعريفها من خلال النظر ِِّ المصنفات التي تحمل هذا الاسهم على تتوعها

(1) تكلم في هذا عامة من اعتتوا بتحقيق كتب 》الفوائد《، وهم كثر، ولعل أوسعهم بحثا

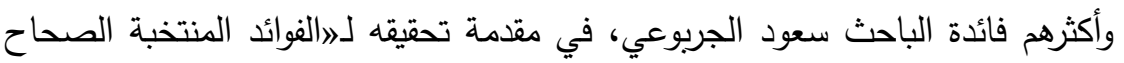

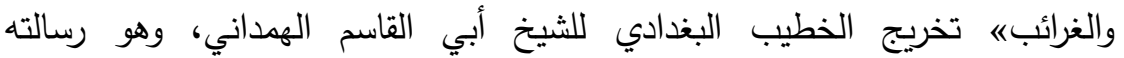
للماجستير بالجامعة الإسلامية، وقد طبعته الجامعة، وقد درس في مقدمته ما يتعلق

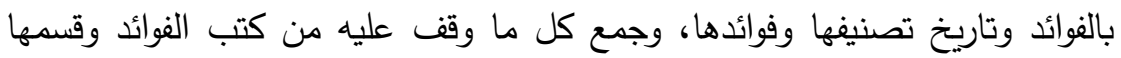

$$
\begin{aligned}
& \text { حسب أنواعها، وقد أحسن وأجاد، وهو مما يستفاد. }
\end{aligned}
$$

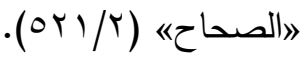

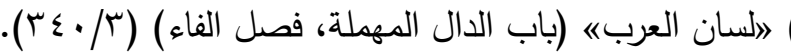

I تـلـيـــــون / 
وتعدد مقاصدها وطرائق تصنيفها ، وقد رأيت جماعة مهن كتب بِّ معنى

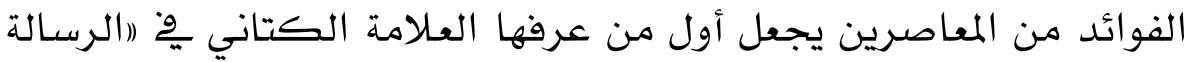
المستطرفة))، وذلك عند تعريفه للأجزاء الحديثية ، فإنه قال: (منها أجزاء

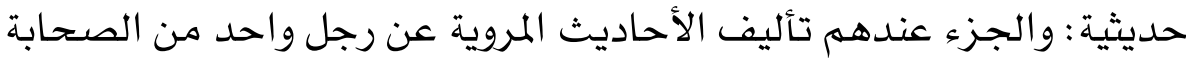
أو من بعدهم، وقد يختارون من المطالب المذكورة پِّ صفة الجامع مطلبا جزئيا يصنفون فيها مبسوطا، وفوائد حديثية أيضا ، ووحدانيات، وثثائيات إلى العشاريات، وأريعونيات، وثمانونيات، والمائة والمائتان وها أشبه ذلك

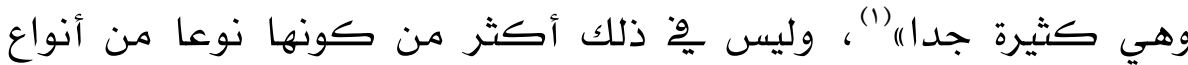

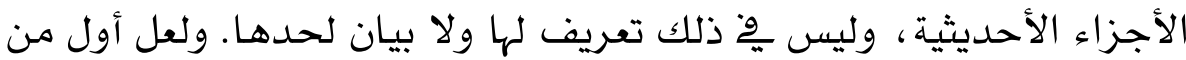

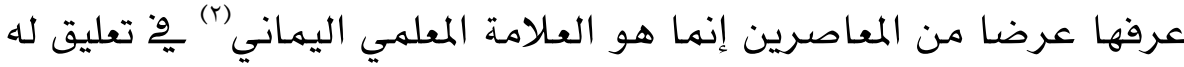

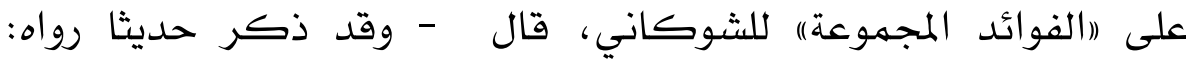

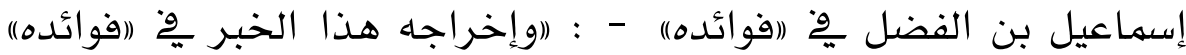

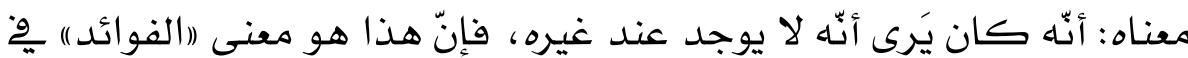

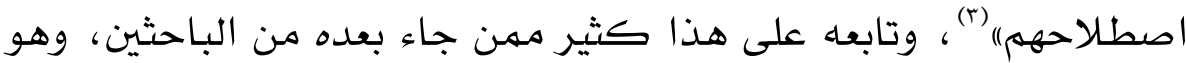

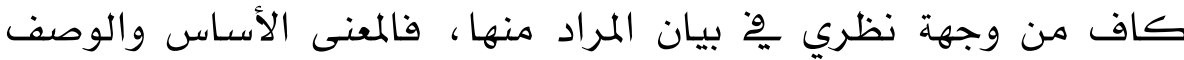

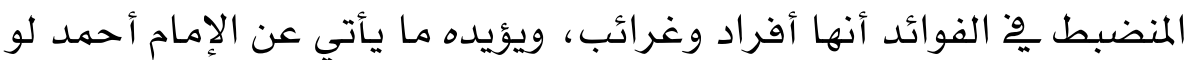
صح عنها، والغريب مشتهر عند أهل الاصطلاح.

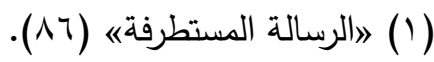

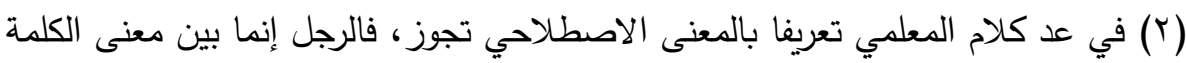
عند أهل الحديث عرضا، ولم يتقصد تحرير تعريف لها.

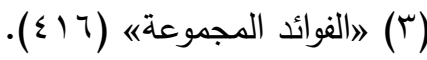

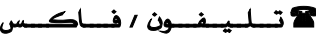


وقد اعترض الباحث سعود الجربوعي تعريف المعلهي بكونه غير

محرر ، وليس جامعا ولا مانعا ، وعرفها هو بأنها: (اما خُرِّج من مرويات

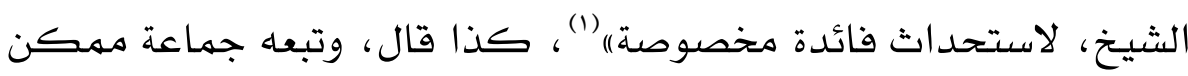
كتبوا بعده، ويؤخذ عليه الآتي: - إغفاله أهم ركن من أركان الفائدة، وهو التفرد والغرابة ، فلم

يظهر بح التعريف، وهذا لا شك خلل كبير. -حصره الفوائد يخ التخريج، وهذا قد يصلح تعريفا لكتب الفوائد، وأمـا الفوائد من حيث ككونها فوائد، فالواقع أعم من هذا فقد تكون تخريجـا، وقد تكون مجرد رواية، ومنـه قول أبي عروبة الحراني فو زهير بن محمد التميهي: ((كان حديثة فوائد)|(r). -وكذلك قوله (الاستحداث فائدة مخصوصة)) معناه أن الفائدة لا تحصل فائدة إلا بالتخريج، وهذ لا وجـه لله، فإن الفائدة حاصلة وحادثة قبل تخريحها ، ولولا كونها فائدة من الأصل لما خرجها مخرج الفوائد.

( (1) مقدمة تحقيق 》الفوائد المنتخبة《 للجربوعي (1/ ( ا ). (Y) 》الكامل《 لابن عدي [Vrr/الرشد]، والذي في 》التهذيب) وغيره ممن نقل عبارة أبي عروبة هذه: 》كأن أحاديثه فوائده، والأمر قريب، وإنما يتم استدلالنا به لو حملناه على له معنى الغرائب المنكرة، ويكون قصده رواية أهل الشام عنه فإنها كذلك، وإلا فإن هناك من الباحثين من يحمله على جودة حديثه، كما تراه في 》المقترح في أجوبة المصطلح" للشيخ الوادعي (9^)، وهو بعيد، ويشوش عليه صنيع الحافظ في 》التهذيب"

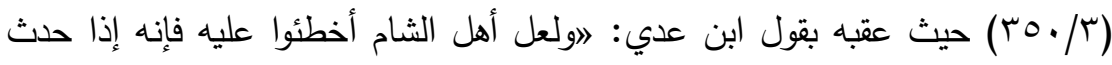
عنه أهل العراق فروايتهم عنه شبه المستقيمة وأرجو أنه لا بأس بهـ.

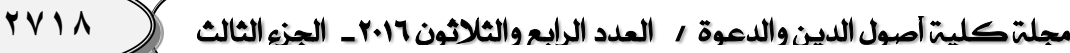

ت تـلـيـفــون / فــاكس 
وقد أسند الخطيب البغدادي ِِّ (الكفاية)) من طريق أَبي بَكِرٍ

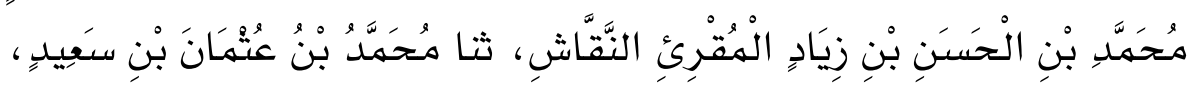

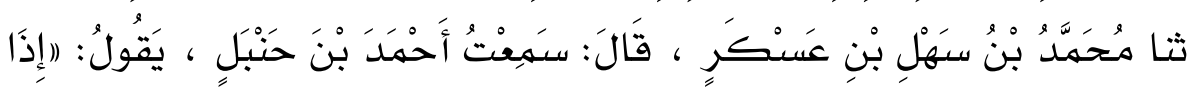

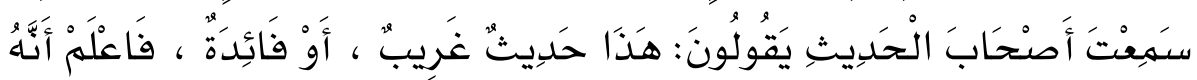

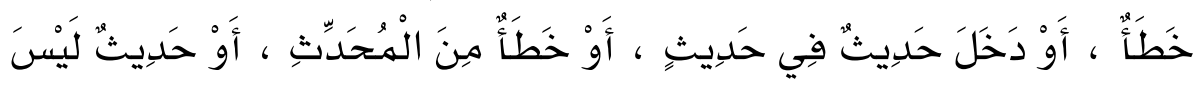

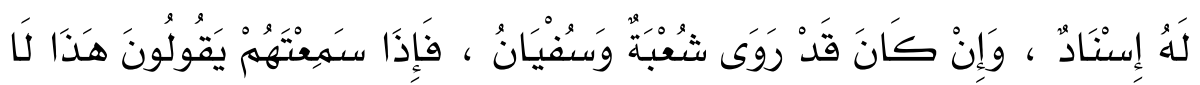

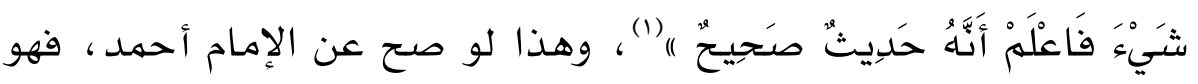
أقدم تعريف للفوائد عند المحدثين، وتكون الفوائد هي الأحاديث الغرائب المستتكرة، وهذا قد يستقيه فيما سهي بالفوائد هكذا بإطلاق، وأما ما قيد بوصف مخالف للنكارة كمن يسهي كتابه بالفوائد الصحاح مثلا، فيكون هذا خارجا عما وصفه الإمام أحمد ، ومستثنى منه، ولا يبقى له من وصف الفوائد المذكورة إلا الغرابة فحسب، أو يكون كلام الإمام أحمد خرج مخرج الغالب، والله أعله.

(1) (الكفاية) (1/ (1)، وإسناده تالف، فإن النقاش واهِ، لا يوثق به ولا بروايته، وانظر

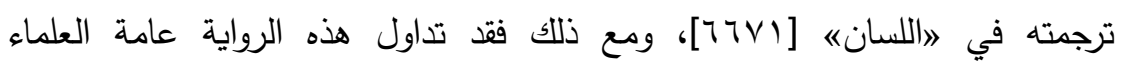
والباحثين دونما نكير، وقد يكون ذلك لضعف الدافع لوضع مثل هذا الكلام، ثم صحته لته في نفسه حتى ولو لم يقله الإمام أحمد، و الله أعلم. 
المطلب الثاني: فو ائد كتب 》الفوائد《

ولهذا النوع من التصانيف فوائد لا تخفى على المشتغل بهذا الفن،

منها على سبيل المثال لا الحصر:

1 - الالتها على عناية المحدثين وحفظهم للأسانيد وإحاطتهم بها ،

ومعرفتهم بالغريب النادر من المثهور المتداول، ولا يقع هذا إلا بالحفظ الواسـع والاطلاع الشديد.

r -تقردها بأسانيد وطرق للأحاديث لا توجد إلا فيها، فهي

$$
\text { مصدر رئيس للأسـانيد والطرق الغريبة. }
$$

r - اشتمالها على بعض اللطائف الإسنادية أو المتتية التي قد تضيف

للطرق المشهورة نوع إيضاح من تعيين مشتبهه ، أو زيادة لفظ موضح، ونحو ذلك مها لا يعد منكرا.

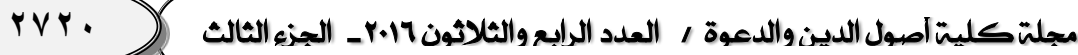


المبحث الثاني

الانتخاب تعريفه، و أشهر أسبابه، وصفة المنتخب.

المطلب الأول: تعريف الانتخاب

الانتخاب لغة: قال ابن منظور : (الانتخاب: الاختيار والانتقاء)|".).

وأما اصطلاحا: فلا يكاد يخرج عن معناه اللغوي، فهو انتقاء

المحدث واختياره بعض الأحاديث من مرويات شيخ ما لصفة ما تجمعها.

المطلب الثاني: أشهر أسبابه

-استخراج الفوائد من حديث شيخ من الشيوخ، ولذا يهكن القول

بأن الفوائد من حيث كونها كتبا وأجزاء حديثية لا تكون إلا منتخبة ، بغض النظر عن منتخبها فقد يكون الشيخ نفسـه أو غيره.

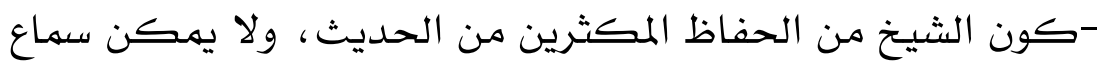

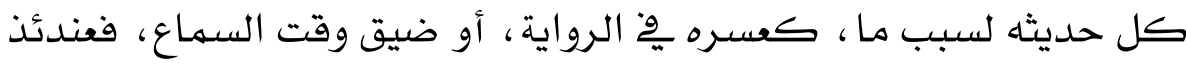

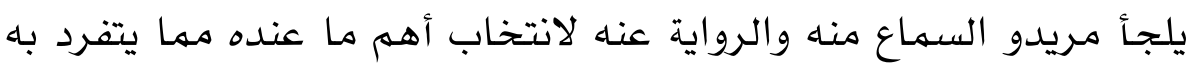

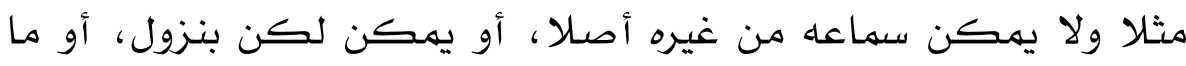
ضبطه تهام الضبط وله به مزيد عناية، أو غير ذلك. قال الخطيب

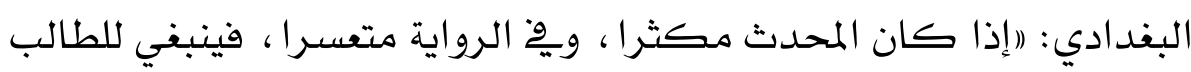
أن ينتقى حديثاه وينتخبها)|(r).

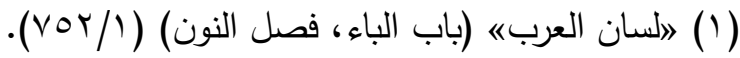

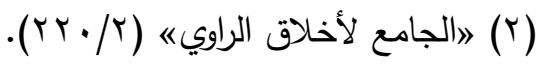


المطلب الثالث: صفة المنتخب

ولا يحسن هذا الباب إلا الحفاظ الكملة المتحققون بهعرفة

الأسانيد والطرق، صحيحها وضعيفها، ومشهورها وغريبها، وأحوال ناقليها، قال الخطيب ٍِّ (الجامع لأخلاق الراوي وآداب السـامع)) : (هن له تعل پِ المعرفة درجته، ولا كملت لانتخاب الحديث آلته، فينبغي أن

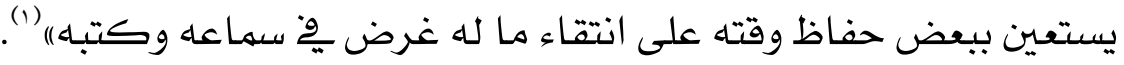
- قال العجلي: (امـا خلق الله تعالى أحداً كان أعرف بالحديث من يحيى بن معين، ولقد كان يجتمع مع أحمد وابن المديني ونظرائهم، فكان هو الذي ينتخب لهم الأحاديث، لا يتقدمـه منهم أحد، ولقد كان كان يؤتى بالأحاديث قد خلطت وتلبست فيقول: هذا الحديث كذا، وهذا كذا،

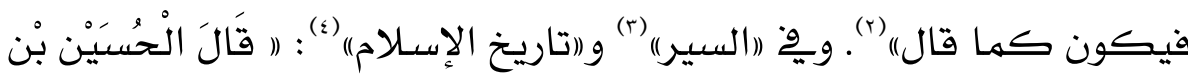

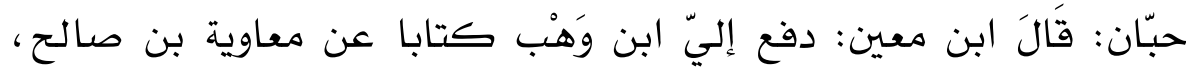

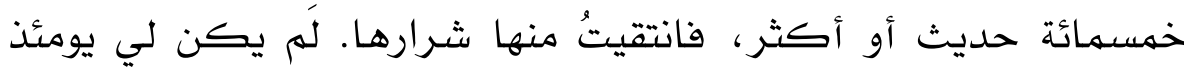
معرفة. قلت: أسمعتها من أحد قبل ابن وهْبَ قَالَ: لاه .قال الذهبي ِو (التاريخ)|: (" يعني أنه كان مبتدثا لا يعرف ينتخب ) وقال يخ (السير)) :

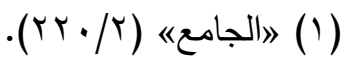

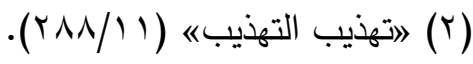

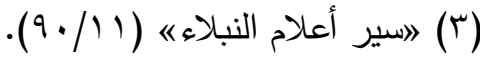

$$
\begin{aligned}
& \text { (تاريخ الإسلامه (970/0). }
\end{aligned}
$$




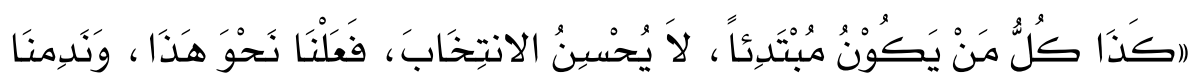

بَعْدُ")

- قال الحاكم أَبُو عَبْد اللَّهِ الْحَافِظ: (قرأت بخط أَبي عَمْرو

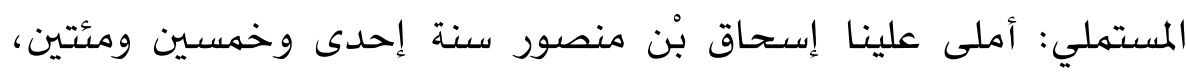
ومسلهم بْن الحجاج ينتخب عليه وأنا أستملي، فنظر إسحاق بْن منصور إلى بـ إنى مسلهم، فقال: لمن نعدم الخير ما أبقاك الله للمسلهـين)|"(1).

- وقَالَ أَبُو أَحْمَدَ بنُ عَدِيٍّ في ترجمة عبيدٍ العِجْلِ تلميذ ابن معين: إكان

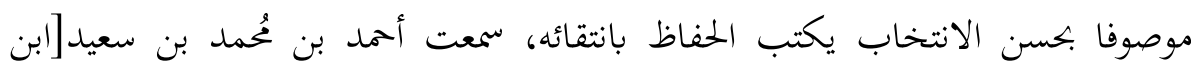
عقدة] يقول: كنا نخضر معه عند من ينتخب عليه وهو شاب، فإذا أخذ الكتاب بيده طار ما في رأسه فنحدثه، ولا يجيبنا فنقول له إذا فرغ: حدثناك ولم تجبنا، قال: فكري فيما

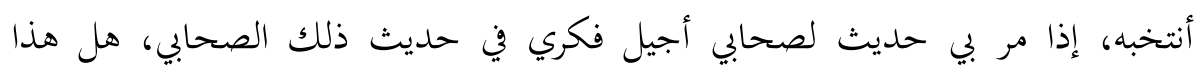
الحديث فيه، أم لا؟ فإني إن أغفلت عن ذلك وأنتم شياطين حَوَالي كل واحد منكم يقول: لم انتخبت لنا هذا، وهذا حدثناه فلان، أو كما قاله" (r).

-وقال ابن عدي: السمعتُ أبا يَعلَّى الموصلي يقول: بات صالح جزرة عندي هَا

هُنا عشر ليال ينتخب على شيوخ الموصل، وكان بطالاه (r).

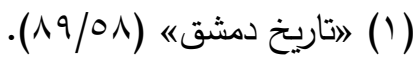

$$
\begin{aligned}
& \text { (Y) }
\end{aligned}
$$

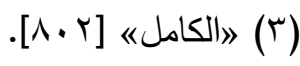


المبحث الثالث: ترجمة القاضي ابن معروف) (1).

اسمه و نسبها، ولقبه:

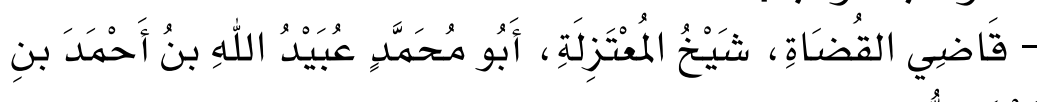

$$
\text { مَعْروفِ البَغْدَادِيُّ. }
$$

- قال التتوخي: (اقال لي أبو الحسـين القاضي ابن قاضي القضـاة

$$
\text { أبي محمد ابن معروف:ولد أبي ِّ2 سنة ست وثثلاث مائة). }
$$

- وقال العتيقي: (اكان مولده سنة ثلاث وثثلاث مائة))، فقال

الخطيب : (هـكذا قال العتيقي وهو خطأ ، والصواب أن مولده سنة ست)).

وظائفه: : واهن

- ولي قضاء القضاة ببغداد بعد أبي بشر عمر بن أكثم، قال العتيقي: ( وكان عفيفا نزها يِّ القضاء للم نر مثله يِّ نزاهته وعفتهاه). - وقال ابن تفري بردي: (اولى القضاء من الجانبين ببغداد).

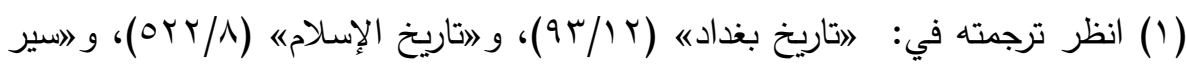

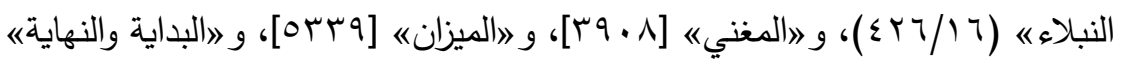

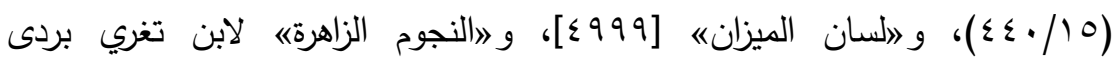

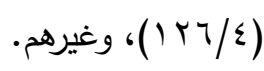




$$
\text { شيبو خه: }
$$

وحدث عن يحيى بن محمد بن صاعد، ومحمد بن إبراهيم بن نيروز، وأحمد بن سليهان الطوسي، وأبي حاهد محمد بن هارون الحضرمي، وجعفر بن محمد بن المغلس، ومحمد بن حبش السراج، ويوسف بن يعقوب، وعبد الله بن محمد بن زياد النيسابوريسين، والقاضي الحسـين المحاملي، وأخيه القاسم المحاملي، ويعقوب بن إبراهيه البزاز، و محمد بن نوح الجنديسابوري، وسهل بن يحيى بن سبـأ الحداد. تلامبذه: حَدَّثَ عنـه أَبو محمد الخهلال، والأزهـري، والعتيقي، والتتوخي، وأحمد بن علي ابن التوزي، وعبد الواحد بن الحسـين بن شيطا ، وأبو جعفر محمد بن أحمد ابن المسلمة ، وغيرهم.

\section{مصنفاته:}

لم أقف لله إلا على هذه الأجزاء التي يهكن نسبتها إليه، وقد حصلتها جميعا ولله الحمد ، وهي:

1 - (اجزء فيها مجلس من أمالي قاضي القضاة أبي محمد عبيد الله ابن معروف)، ، وهو من رواية أبي جعفر ابن المسلمة ، عنهاه وقد نقل منـه الحافظ ابن عساكر نصا يُّ (تاريخ دمشق)" (Y / ع ا ) بسنده إليه، وهو من مسهوعات الحافظ ابن حجر كهما يخّ (المعجم المفهرس)" [1001]،

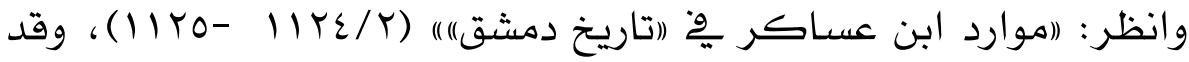

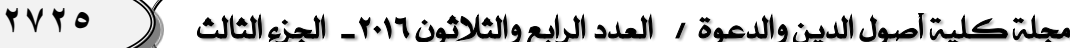


وقفت على المجلس السـادس من هذه المجالس بخط القلقشندي وسهاعها على ابن حجر ، وهو من محفوظات مكتبة جامعة النجاح الوطنية بنابلس. r - (الفوائد المنتقاة الغرائب) بانتخاب الدارقطني، وهو كتابنا

r - "اجزء فيه من حديث قاضي القضاة أبي محمد ابن معروف ومن حديث أبي بكر محمد بن إسماعيل الوراق) برواية ابن حسنون النرسي عنهما ، وفيها من حديث أبي الحسن الباقلاني، وتوجد منه نسخة

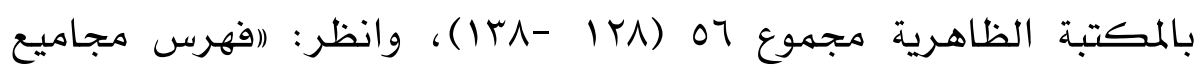

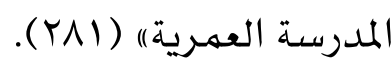

ع - - (الجزء الخامس من الفوائد المنتقاة الحسان لابن معروف)| بانتقاء الدارقطني، رواية الجوهري عن ابن معروف، وتوجد منه نسخة

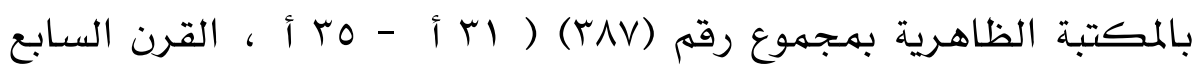
الهجري). (باله

\section{ثناء العلماء علبه:}

- قال الخطيب: (وكان ثقة))، ثم قال:( وكان من أجلاء الرجال، وألباء الناس، مع تجرية وحنكة ومعرفة وفطنة ، وبصيرة ثاقبة ،

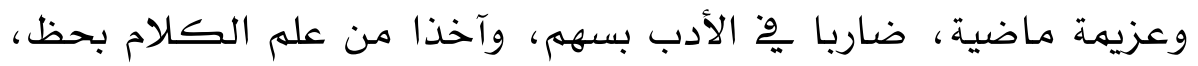

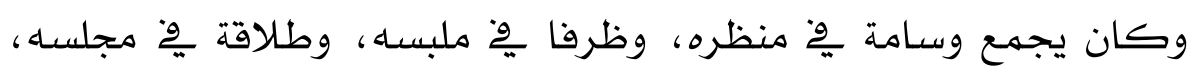


وبلاغة وِّ خطابه، وعفة عن الأموال، ونهوضا بأعباء الحكام، وهيبة ِ2:

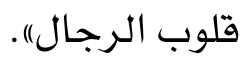

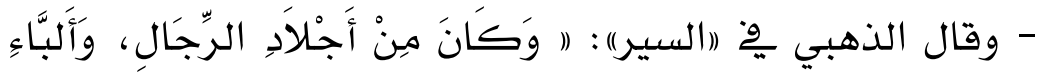

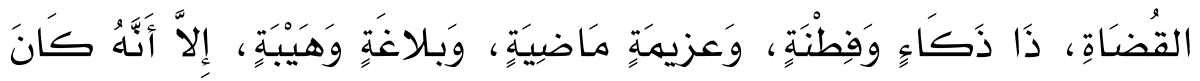

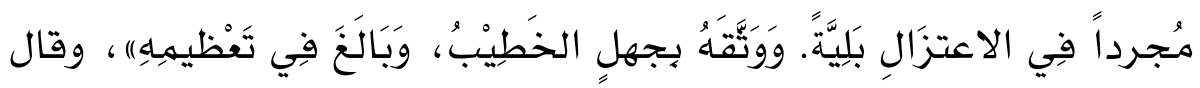

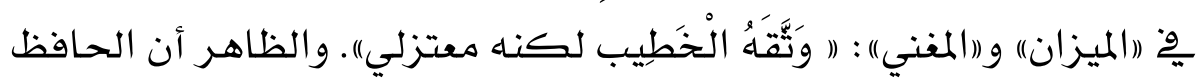

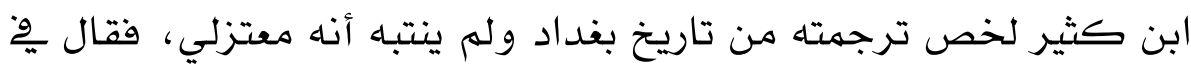

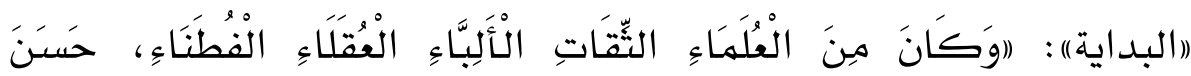

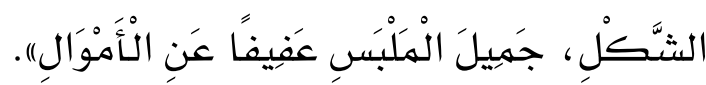

- وقال العتيقي: اوكان له وِّ كل سنة مجلسان يجلس فيهما للحديث، أول يوم من المحرم، وأول يوم من رجب، وله يكن له سماع كثير وكان مجردا ِِّ مذهب الاعتزال، وكان عفيفا نزها ِوْ القضاء له

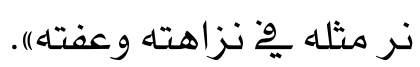

- وقال أبو القاسهم التتوخي: (اككان الصاحب أبو القاسهم بن عباد، يقول: كنت أشتهي أن أدخل بغداد فأشاهد جُرأة محمد بن عمر العلوي، وتتسك أبي أحمد الموسوي، وظَرْف أبي محمد ابن معروف).

- وقال ابن تفري بردي: (وكانت لله منزلة عالية من الخلفاء والملوك خصوصا من الطائع، وكان من العلماء التّقات الفضلاء العقلاء). برئ. 


\section{عقبدته:}

سبق يخُ ككلام العتيقي، والذهبي أنه كان من المعتزلة. وقد نشـأ الرجل يُّ دولة البويهيين، وهي دولة الروافض، وقد كان التشيع والاعتزال ضاربا بجرانه يومئذ، حتى قال الذهبي معلقا على وصف أبي القاسـم التتوخي - وهو تلميذ ابن معروف - بالتشيع والاعتزال: (نشـأ ِِّ الدولة البويهية ، وأرجاؤها طافحة بهاتين البدعتين)" (1). شنـعر ه:

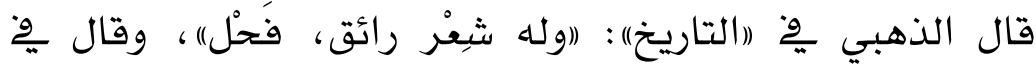
(السير)") : (الك نظم رائق)).

فمن ذلك: ما قال التتوخي: (بلغني أن أبا محمد ابن معروف جلس يوما للحكىم فِ جامع الرصافة ، فاستدعى أصداب القصص إليه فتتبعها ووقع على أكثرها، ثم نظر پِّ بعضها، فإذا فيها ذكر له بالقبيح، وموافقته على وضاعته وسقوط أصله، ثم تتبيهه وتذكيره لأحوال غير جميلة ، وتعديد ذلك عليها ، فقلب الرقعة وكتب على ظهرهـا:

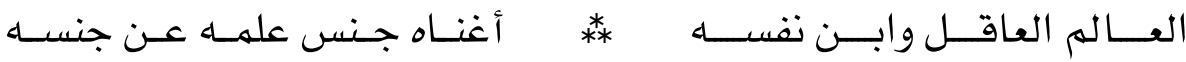

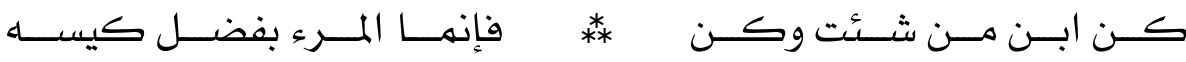

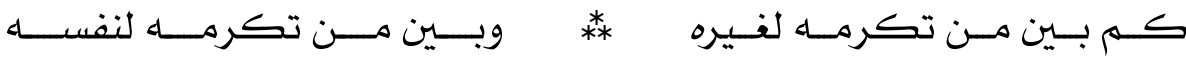

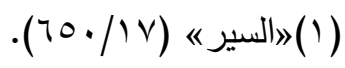

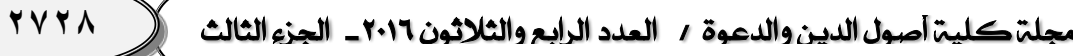


مـــن إنهــــا حياتــــه لغنــيره

وقال القاضي أبو عصمة اللخمي: أنشدني قاضي القضاة ابن معروف

لنفسها بيغداد مضهنا البيت الأخير:

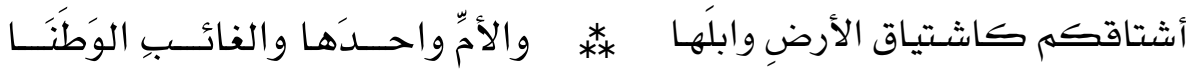

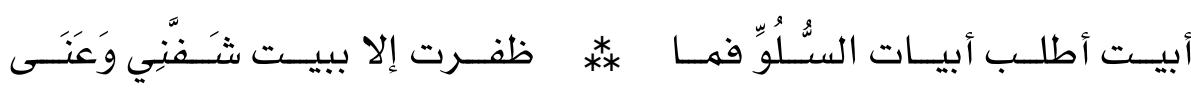

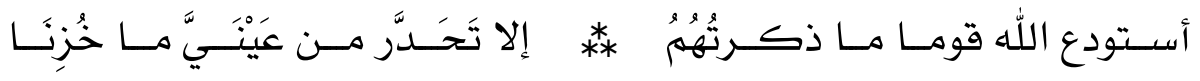

\section{وفاته:}

قال العتيقي: 》اسنة إحدى وثمانين وثلاث مائة، فيها توفي قاضي القضاة أبو عُمَّم عبيد الله بن أحمد بن معروف، يوم السبت لسبع خلون من صفر، وصلى عليه في داره أبو أحمد الموسوي العلوي، وكبر عليه خمسا، ثم حمل تابوته إلى جامع المنصور، وصلى عليه ابنه وكبر أربعا، وحمل إلى داره على شاطئ دجلة ودفن فيهاء.

وقال القاضي أبا العلاء الواسطي: لالما مات قاضي القضاة أبو تُحَّمَ ابن معروف

حضر أبو القاسم عيسى بن علي بن عيسى الوزير عزاءه، فقال للقاضي أبي الحسين ابنه:

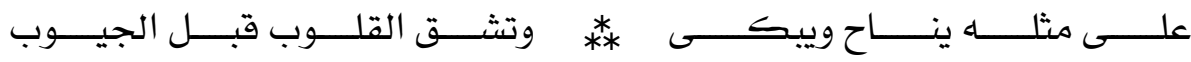
الحمد لله الذي له ينقله من داره إلى جواره حتى أخرج من عنصره مثلك).

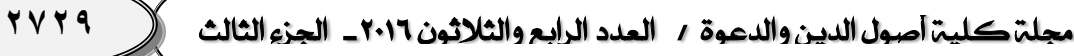




\section{المبحث الرابع}

ترجمة مختصرة للإمام الدر اقطني، وبيان عنايته بالانتخاب'(1).

المطلب الأول: ترجمة مختصرة للاقطني

$$
\text { اسمه و نسبه وكنيته ولقبه }
$$

هو الإمام الحافظ المجود، شيخ الإسـلام، علم الجهابذة، أبو الحسن علي بن عمر بن أحمد بن مهدي بن مسعود بن النعمان بن دينار بن

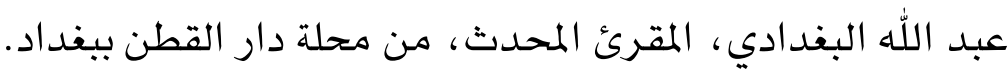

(1) الدارقطني أشهر من علم في رأسه نار ، وقد ترجم له عامة من عمل على تحقيق شيء

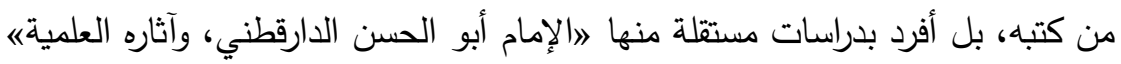

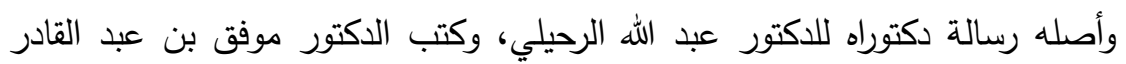

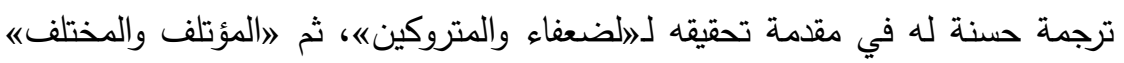

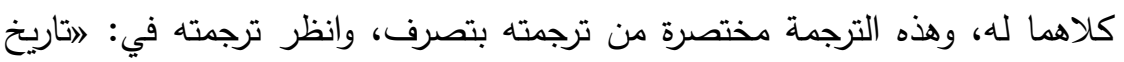
بغداده (r (

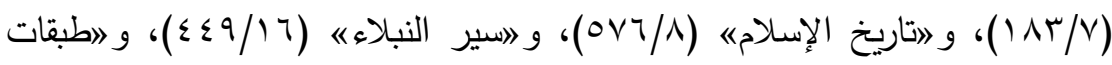

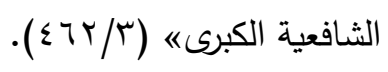




$$
\text { مولده }
$$

ولد سنة ست وثلاثمئة، وقيل سنة خمس وثلاثهئة، ونقل الخطيب القولين، ولكنه صدر كلامه بالقول الأول ويرجح القول الأول تصريح

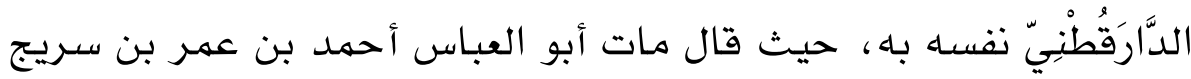
القاضي الفقياه سنة ست وثلاثمئة ، وولدت عِّهـ هذه السنة. طلبه للعلم كان والد الدَّارَقُطْنِيّ من المعتتين بالعلهم، ومن المحدثين الثقات، وقد حرص على تعليه ولده وهو صغير، كما أنه بدأ الكتابة وهو صبي، فقد قال عن نقسـه كتبت ِِّ أول سنة خمس عشرة وثلاثهئة، وكان يحضر مجلس البغوي منذ نعومة أظافره، قال يوسف القواس كنا نمر إلى نـ

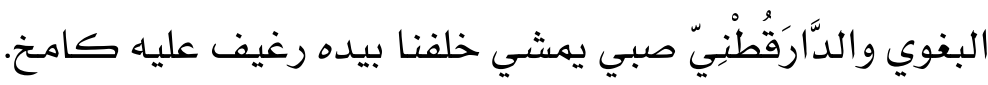
ونقل ابن عساكر يخ تاريخ دمشق عن القواس قوله كنا نهر إلى ابن منيع والدَّارَقُطنْيّ صبي خلفنا بيده رغيف عليه كامتخ، فدخلنا إلى ابن

$$
\text { منيع، ومنعناه، فقعد على الباب يبكي. }
$$

بعد أن سهع الدَّارَقُطْيْيِ شيوخ بلده، ارتحل إلى البصرة،

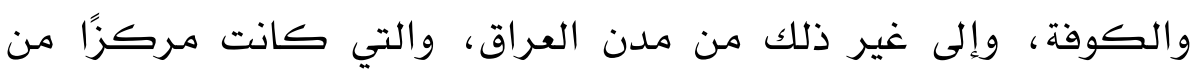
مراكز العلم والعلماء، فقد ارتحل إلى واسط للقاء شيوخها والرواية عنهم، ورحل إلى البصرة يِّ حدود العشرين وثلاثثئة، كها أنه رحل إلى الكوفة للسماع من الحافظ أبي عبد الله محمد بن القاسهم بن زكريا الكويخٌ 
السوداني، ورحل إلى الشام، ومصر، و والحجاز، قال الحاكم: دخل

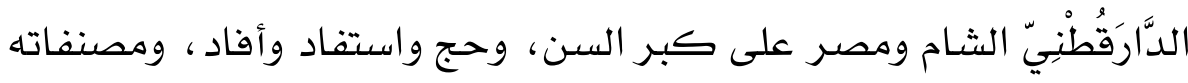

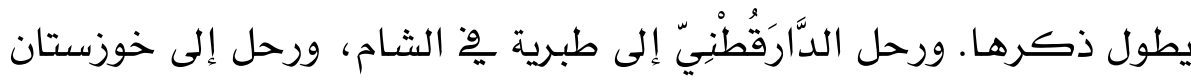
للسهماع من شيوخها. شيوخه وتلاميذه

سمع أبا القاسم البغوي، وأبا بكر بن أبي داود ، ويحيى بن صاعد ، وبدر بن الهيثم القاضي، وأحمد بن إسـحاق البهلول، وعبد الوهـاب بن أبي حية، والفضل بن أحمد الزبيدي، وأبا سعيد العدوي، ويوسف بن يعقوب النيسابوري، وأبا حامد بن هارون الحضرهي، وسعيد بن محمد أخا زبير الحافظ، ومحمد بن نوح الجنديسابوري، وأحمد بن عيسى بن السكين البلدي، وإسهاعيل بن العباس الوراق، وإبراهيم بن حهاد القاضي، وعبد الله بن محمد بن سعيد الجمال، وأبا طالب أحمد بن نصر الحافظ، وخلقًا كثيرًا من هذه الطبقة ، وهن بعدهم. حدث عنه الحافظ أبو عبد الله الحاكم، والحافظ عبد الغني، وتمام بن محمد الرازي، والفقيه أبو حامد الإسفراييني، وأبو نصر بن الجندي، وأحمد بن الحسن الطيان، وأبو عبد الرحمن السلهي، وأبو مسعود الدمشقي، وأبو نعيم الأصبهاني، وأبو بكر البرقاني، وأبو الحسن العتيقي، وأحمد بن محمد بن الحارث، الأصبهاني النحوي، والقاضي أبو الطيب الطبري، وعبد العزيز بن علي الأزجي، وأبو بكر محمد بن عبد الملك بن بشران، وأبو الحسن بن السمسـار الدمشقي، وأبو حازم بن الفراء

ت تــــــــون / فــاكسن 
أخو القاضي أبي يعلى، وأبو النعمان تراب بن عمر المصري، وأبو الغنائم

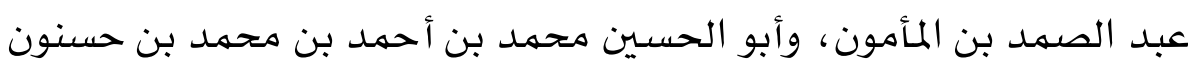
النرسي، وحمزة بن يوسف السهمي، وخلق سواهم من البغاددة، والدماشقة ، والمصريين. أقو ال العلماء فيه وثناؤ هم عليه

قال الخطيب البغدادي: (اكان فريد عصره، وقريع دهره، ونسيج وحده، وإمام وقته، انتهى إليه علم الأثر والمعرفة بعلل الحديث، وأسماء

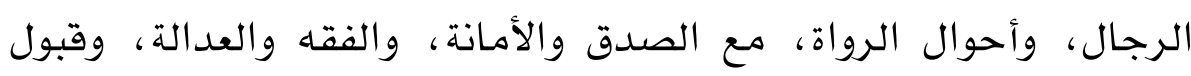
الشهادة، وصحة الاعتقاد، وسـلامة المذهب، والاضطلاع بعلوم سوى علم

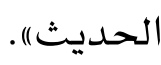

وقال الأزهري: (اككان الدَّارَقُطْنِيّ ذكيَّا إذا ذوكر شيئًا من العلم أي نوع كان وجد عنده منـه نصيب وافر |). وقال أبو الطيب طاهر بن عبد الله الطبري: (اككان الدَّارَقُطنْيِّ أمير

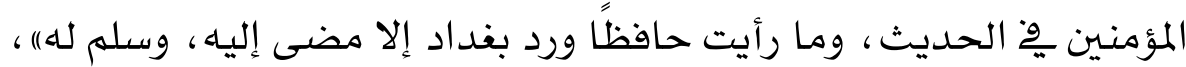

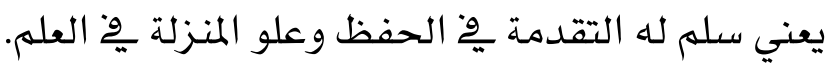
وقال عبد الغني الأزي: (أحسن الناس ككلامًا على حديث رسول

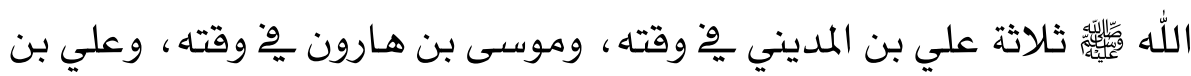

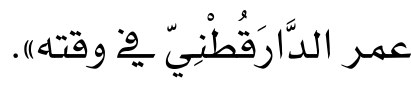


وقال البرقاني: (اكنت أسمع عبد الغني بن سعيد الحافظ كثيرًا

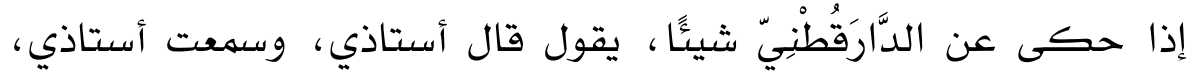
فقلت له وِّ ذلك، فقال: وهل تعلهنا هذين الحرفين من العله إلا من أبي

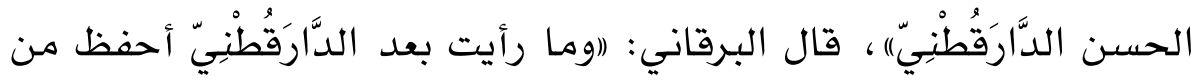
عبد الغني بن سعيد).

وقال الأزهري: (ابلغني أن الدَّارَقُطْيّيّ حضر ِِّ حداثته مجلس إسهاعيل الصفار، فجلس ينسخخ جزءًا كان معه وإسهاعيل يملي، فقال: له اله

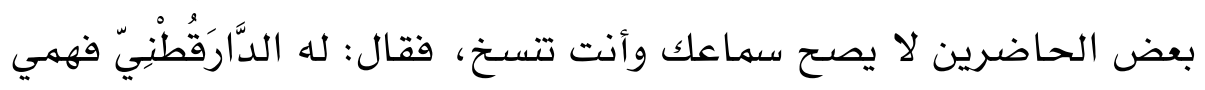
للإمهلاء خلاف فهمك، ثم قال تحفظ كمم أملى الشيخ من حديث إلى الآن ؟

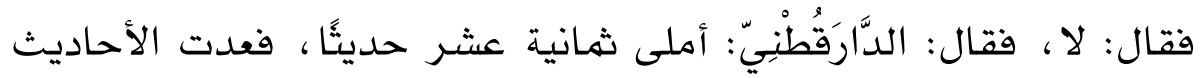

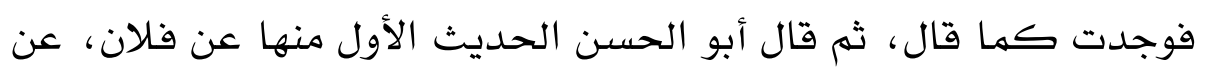
فلان، ومتته كذا، والحديث الثاني عن فلان، عن فلان، ومتته كذا، وله يزل يذكر أسـانيد الأحاديث بمتونها على ترتيبها مِّ الاملاء حتى أتى ولى على آخرها ، فتعجبت الناس منه - أو كما قال). وقال الحاكم: (أبو عبد الله محمد بن عبد الله الحافظ - وسئل عن الدَّارَقُطْنِيّ - فقال: ما رأى مثل نفسـهاه). وقال محمد بن أبي الفوارس، وقد سـأل أبا الحسن الدَّارَقُطْيِيّ عن علة حديث، أو اسم فيه فأجابه، ثم قال لهه: ( يا أبا الفتح، ليس بين الشرق والغرب من يعرف هذا غيري).

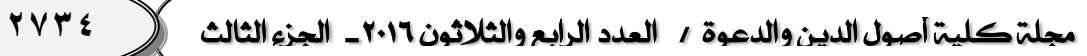

ت تـلـيـفــون / فــاكـس 


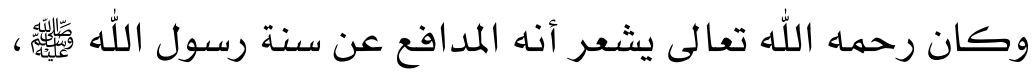
الحامل لواءها ، فقد قال: (ايا أهل بغداد، لا تظنوا أن أحدًا يقدر يكذب وحنب

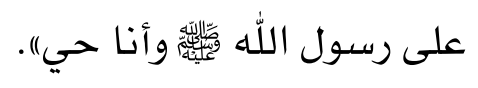

وقال الذهبي: وكان من بحور العلم، ومن أثمة الدنيا، انتهى إليه الحفظ ومعرفة علل الحديث ورجاله، مع التقدم پِّ القراءات وطرقها، وقوة المشاركة يخ الفقه، والاختلاف، والمغازي، وأيام الناس، وغير ذلك. وقال ابن كثير الحافظ الكبير أستاذ هذه الصنعة ، وقبله وبعده، إلى زمانتا هذا، سمع الكثير وصنف وألف وأجاد وأفاد، وأحسن النظر والتعليل، والانتقاد والاعتقاد، وكان فريد عصره، ونسيج وحده ء وإمام

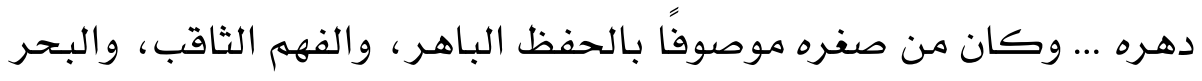
الزاخر.

\section{وفاة الدَّارَفُطْنِيّ}

قال الخطيب البغدادي: حدثنا أبو الحسن بن الفضل، قال قال لي

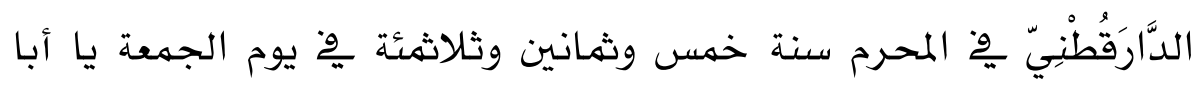
الحسن، اليوم دخلت بِّ السنة التي تويِّ لي ثمانين.

قال ابن الفضل وتوبِ ِِّ ذي القعدة من هذه السنة، واختلف الشهر الذي تويْ فيه هل هو شهر ذي القعدة، أم شهر ذي الحجة ؟ورجح الخطيب أن وفاته كانت فِّهر شهر ذي القعدة.

$$
\text { ودفن قريبًا من قبر معروف الكرخي. }
$$

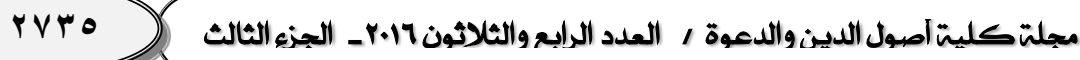

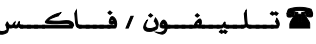


قال ابن الصلاح رحمه الله تعالى (اسبعة من الحفاظ أحسنوا التصنيف وعظم الانتفاع بتصانيفهم پِ أعصارنا) وبدأ بأبي الحسن

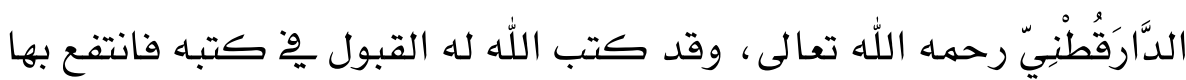
الناس من وقته إلى الآن واحتفوا بها وأنزلوها منزلتها ، ومن أشهرها: ("كتاب السنن)"، و (العلل)، و (الضعفاء والمتروكون)"، وغيرها ، وكلها مطبوعة متداولة مشتهرة.

المطلب الثاني: عناية الدارقطني بالانتخاب

كما سبق يخٌ الحديث عن الانتخاب، فإنه لا ينتخب إلا الحفاظ

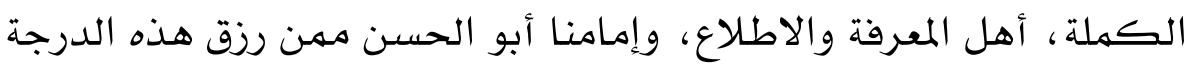
العالية، ولذا كان مؤهـال لهذا الأمر، متحققا بإتقانه، مشتهرا ببراعته فيه، و و قد انتخب الكثير، حتى أحصى بعض الباحثين انتخابه على نحو

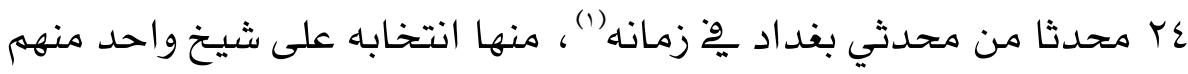
تهام مائة جزء كها سيأتي، فها ظنك ببقيتهم بل بهن خارج بغداد؟؛ وهمن

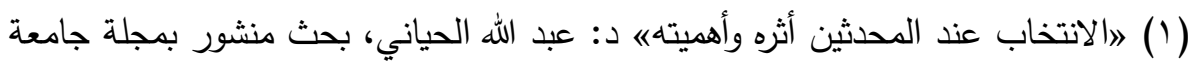

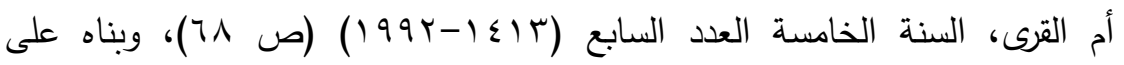
إحصائه الخاص ما في "تاريخ بغداده من التتبيه على ذللك، ولم يسق تفصيل ذللك، وقد ذكرت عاليه ما وقفت منه على تفاصيله.

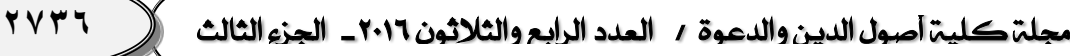


وقتت عليه ممن انتخب الدارقطني من حديثهم وروى الناس بانتخابه مهن ذكرهم الخطيب ِّْ (تاريخها)):

1

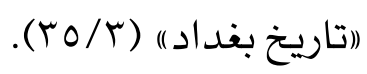

r - محمد بن عبد الله بن محمد بن عبيد الله أبو المفضل

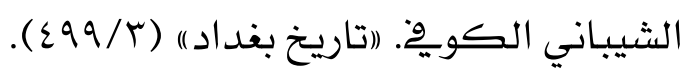

r - محمد بن عمر بن يحيى بن الحسـين بن أحمد بن عمر بن يحيى بن الحسـين بن زيد بن علي بن الحسـين بن علي بن أبي طالب أبو الحسن العلوي من أهل الكوفة. (تاريخ بغداد)) (ع / عه).

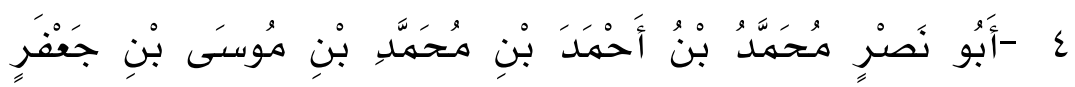

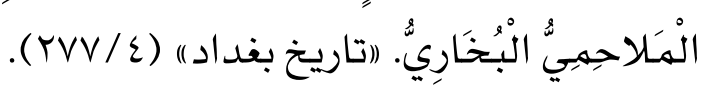

0

$$
\text { الطبري كَانَ أبوه من أهل همدان. ("تاريخ بغداد) (IVY/O). }
$$

1

$$
\text { الحريري ويعرف بالمشطاحي. (اتاريخ بغد اده) (0) V/O). }
$$

- V

$$
\text { بغداد) (T/YT/). }
$$


1 - إبراهيم بن محمد بن إبراهيم بن محمد أبو إسحاق التاجر

$$
\text { المروزي ويعرف بالزجاجي. (تاريخ بغداد)) (9/V ( ). }
$$

9 - إستحاق بن سعد بن الحسن بن سفيان بن عامر بن عبد العزيز

بن النعهان بن عطاء أبو يعقوب الشيباني النسوي. (اتاريخ بغداد)" (V/Vع)).

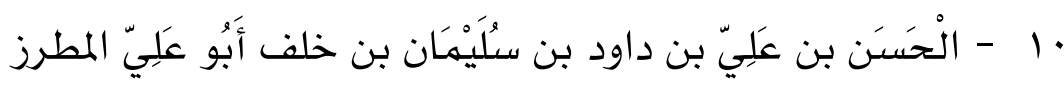

$$
\text { المصري. ((تاريخ بغداد)" (1/ •وب). }
$$

11

$$
\text { الرفاء الهروي. (اتاريخ بغداد)" (ب/9 ع). }
$$

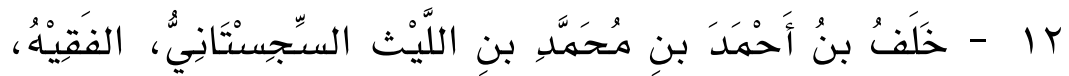

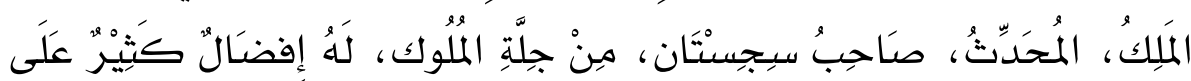

$$
\text { أَهْلِ العِلْم. (السير)" (I T/IV ) }
$$

r ا - عبيد الله بن محمد بن حمدويه أبو الحسن الوزير. (اتاريخ

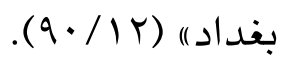

rا - عبد الملك بن الحسن بن يوسف بن الفضل أبو عمرو المعدل،

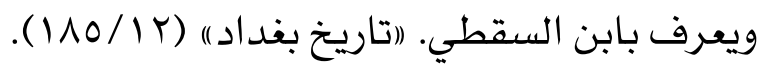

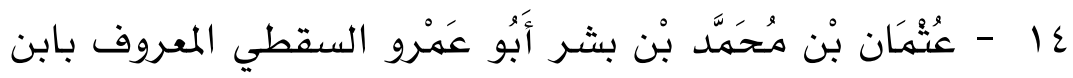

$$
\text { سَنْقة. ((تاريخ بغداد ) (r/ / (19r). }
$$

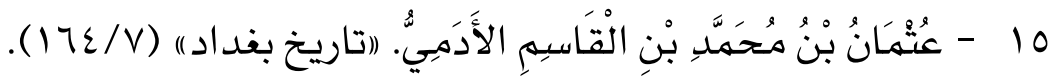

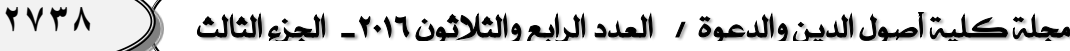

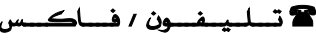


17

$$
\text { بغداد) (OVY/IT). }
$$

وقد كان انتخاباه رحمه الله انتخاب عارف مطلع متقن لا يكاد

يفوته من مواضع الفائدة والإجادة شيء، فقي ("تاريخ بغداد)) : (وقد كان أبَو

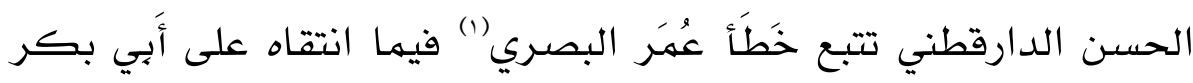
الثافعي خاصة، وعمل فيه رسالة إلَّى طاهر ابْن مُحَمَّد الخَارِكِيّ،

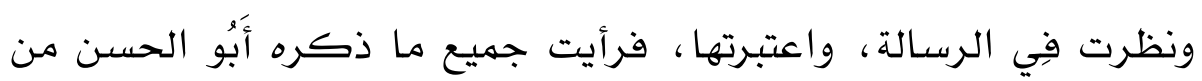

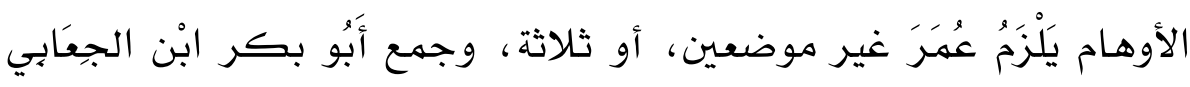

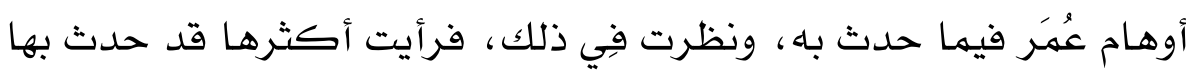
عُمَر على الصواب، بخلاف مـا حكى عنـه الجعابي. وسمعت أبا بكر البرقاني، وذاكرته بخطأ عُمَر البصري، وتَتَبُع

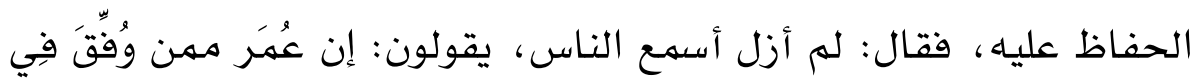

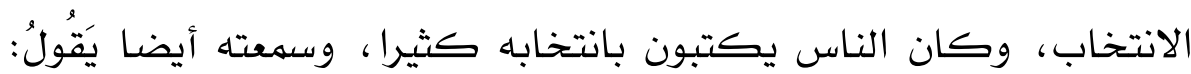

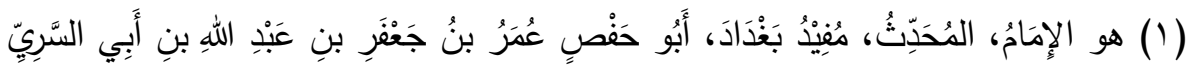

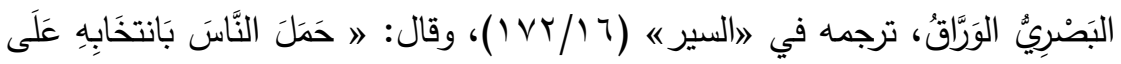

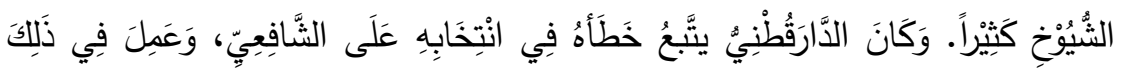

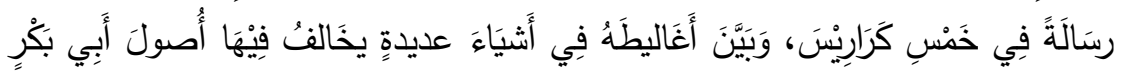

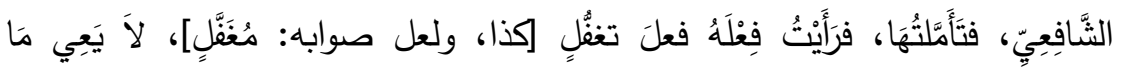

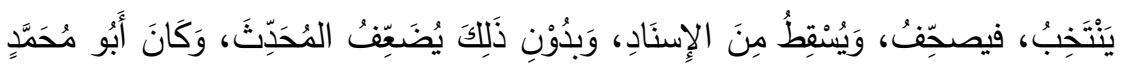

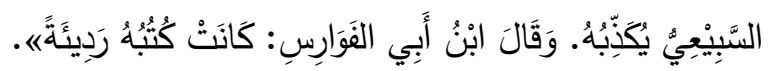


كان عُمَر قد انتخب علي ابْن الصواف، أحسبه قَالَ: نحوًا من عشرين

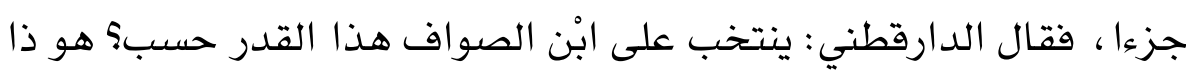
أنتخب عليه تمام المئة جزء، ولا يكون فيما انتخبه حديث واحد هما انتخبه عُمَر، فقعل ذلك. وسهعت غير البرقاني يذكر أن هذه القصة

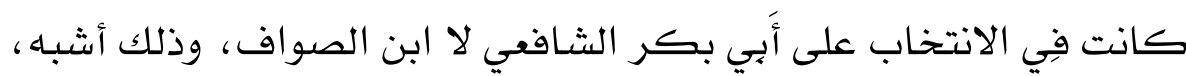
والله أعلم" "(1).

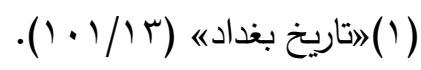

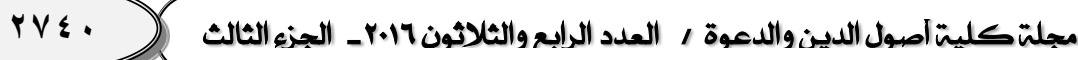


المبحث الخامس: التعريف بالجزء ووصف النسخة الخطية،

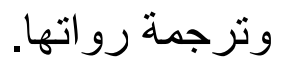

المطلب الأول: التعريف بالجزء

هذا الجزء هما انتخبه الإمام الدارقطني من حديث القاضي عبيد

الله ابن معروف البغدادي المعتزلي، وقد جرى فيه على انتخاب الطرق الغرائب فحسب، وعامة الأحاديث المذكورة فيه متونها مشهورة، بل كثير

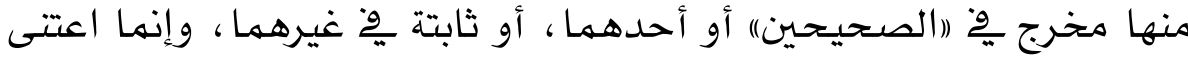
الدراقطني بتخريج طرق لله غريبة غير مشتهرة، فهـموع أحاديث هذا الجزء المنتخب واحد وعشرون حديثا (Y)، منها ستة (7) أصولها (الصحيحين)، واثتان (Y) أصلهما ِِّ (صحيح البخاري)"، وخمسة (0)

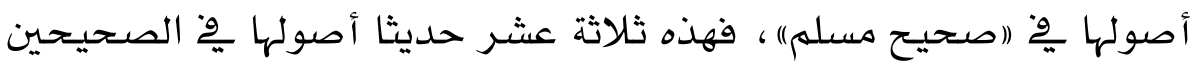
أو أحدهما ، وأربعة أحاديث (ع) أصولها ِِّ (السنن) ونحوها وهي ثابتة ِخ الجملة، فهذه سبعة عشر حديثا (IV) منها أصولها ثابتة، ويبقى فقط (ع) أحاديث لا تثبت.

المطلب الثاني: وصف النسخة الخطية، وفيه ترجمة رو اتها

$$
\text { وسماعاتها }
$$

لم أقف لهذا الجزء إلا على هذه النسخة الوحيدة التي حفظت

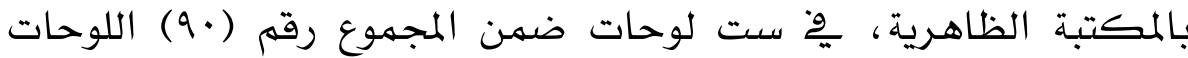

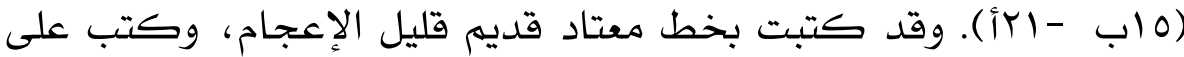
طرتها: 
(الجزء من الفوائد المنتقاة الغرائب

انتخاب الشيخخ أبي الحسن علي بن عمر الدارقطني

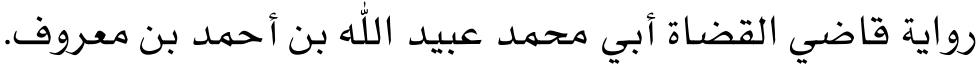

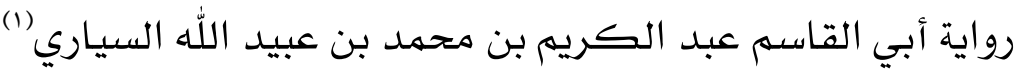

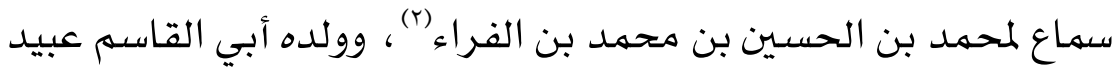

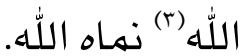

(1) هو عبد الكريم بن ححم بن عبيد الله بن يوسف، أبو القاسم الدلال المعروف بالسياري،

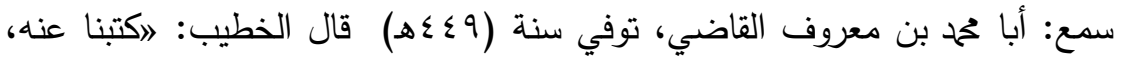
وكان صدوقاه، وسأله الخطيب أيضا: 》هل سمعت توفي من غير ابن معروف؟ قال: لاهـ.

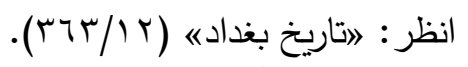

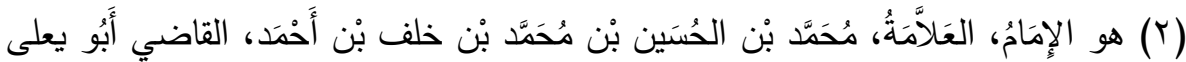

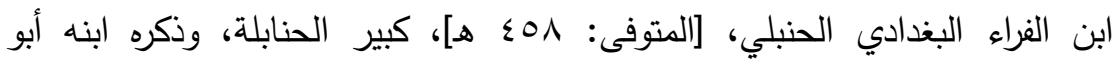

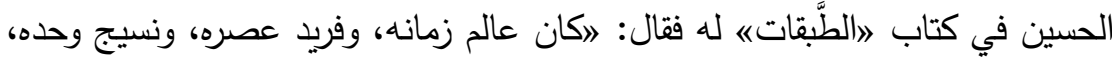

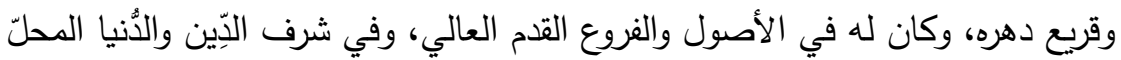

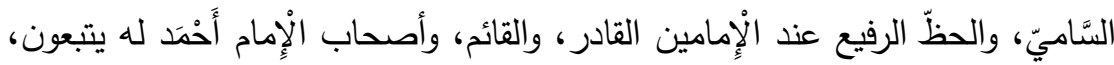

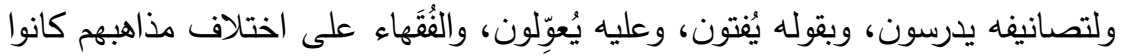

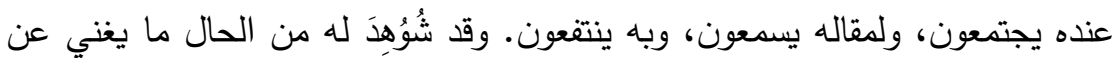

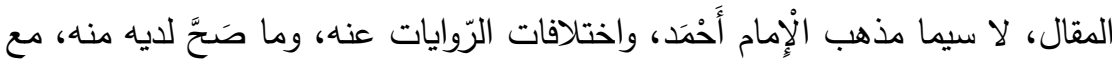

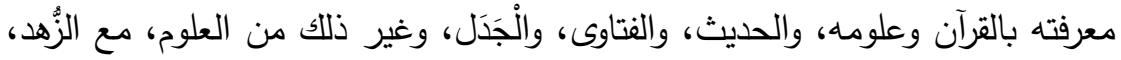

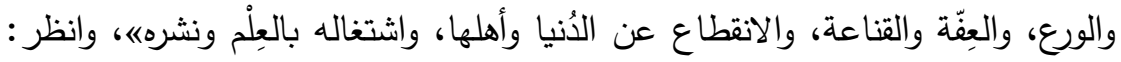

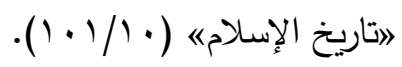

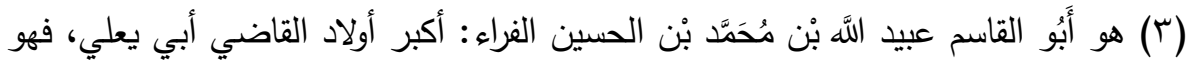

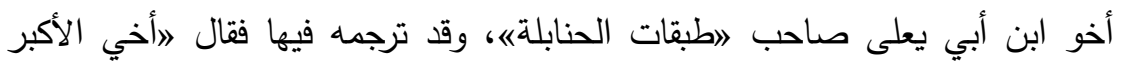
الشاب العالم الورع الصالح،. .. وذكر سماعه من الجوهري الذي نصل عليه أبوه= 
وهو أول سماعه معي وبحضرتي، وكان له خمس سنين زِيدَ إتهامًا (1)،

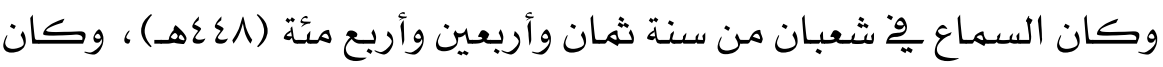
قد سهع من ابن الجوهري، ولها دون هذا السنسا.

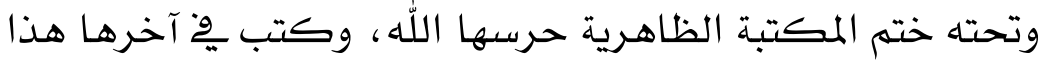
السهاع كذلك: (ر قرأت جميع هذا الجزء على الشـريف الأجل أبي الحسن

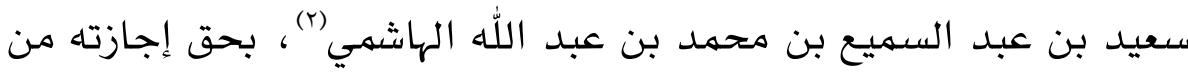
أبي غالب ابن البناء(r)، بإجازته من القاضي أبي يعلى محمد ابن الفراء(')

=القاضي أبو يعلى هنا عاليه، ثم قال.... وكان الوالد السعيد يأتم به في صلاة التراويح

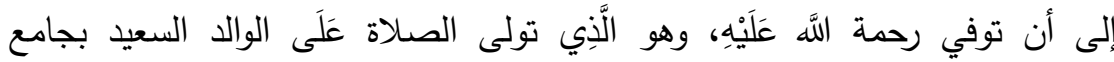

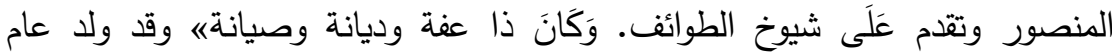

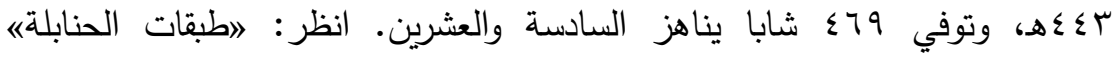
(rro/r) (1) كذا قرأتها، ولعله يعني أنه كان دون خمس سنين بقليل فزيد ليتم له خمس سنين فيصح تحمله وسماعه، و الله أعلم. هو سَعِيد بْن عَبْد السميع بْن مُحَمَّد بْن شجاع، أَبُْو الْحَسَن الهاشهيّ، الْبَغْدَادِيّ.

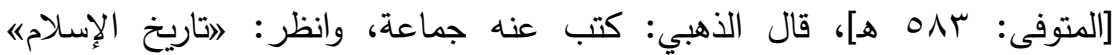

$$
\cdot(\vee \circ 9 / 1 r)
$$

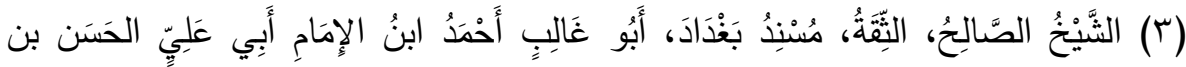

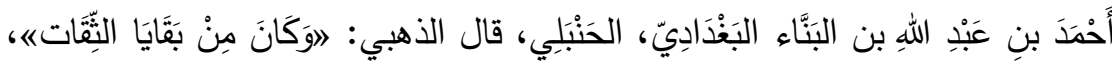

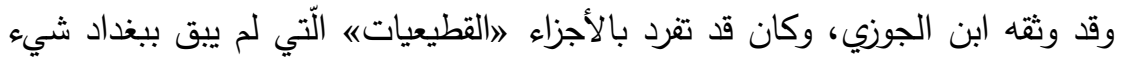

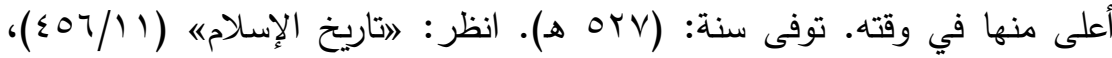

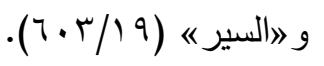


رضي الله عنه، فسمعه الشيخ الأجل العالم أبو البركات إسماعيل بن

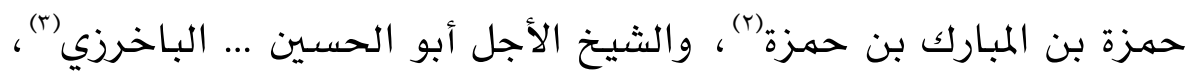
والأجل الصالح أبو الخير صبيح بن عبد الله الحبشي عتيق العطار(ع)، وعمر بن ... الخراط")، وكتب أحمد بن محمد بن بن محمد بن محمد الفراء(7)، وذلك يوم الجهعة عاشر ربيع الأول من سنة إحدى وثمانين

$$
\text { (1) سبقت ترجمته وهو القاضي الجليل أبو يعلى. }
$$

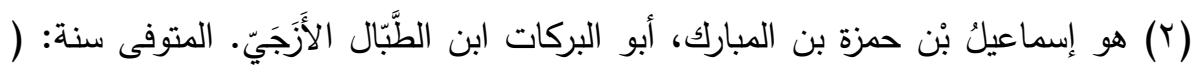

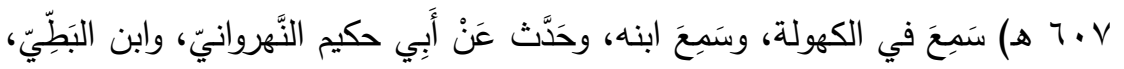

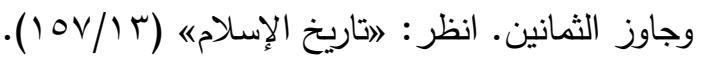

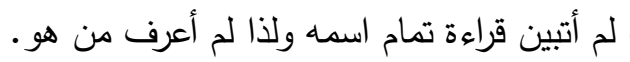

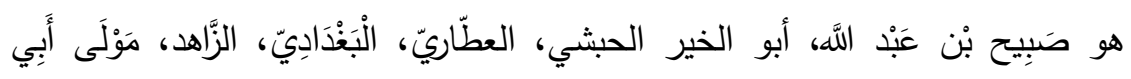

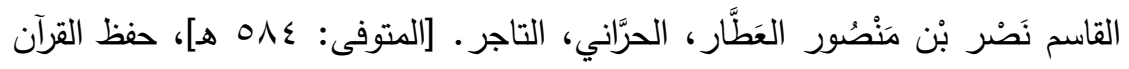

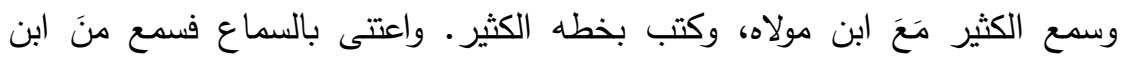

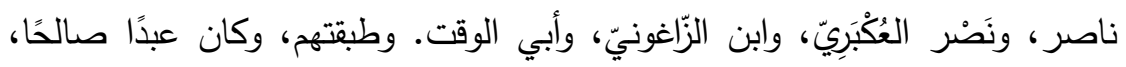

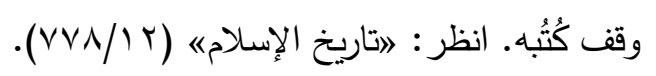

(0) وقع في النسخة (عمر بن (بياض) الخراط) فلم أتبين هو اسم أو أكثر ، ولذا لم أعرف الإن

$$
\text { من هو }
$$

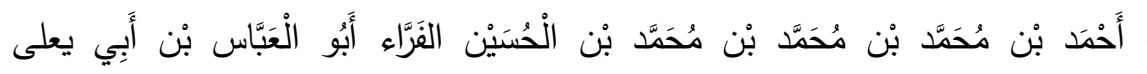

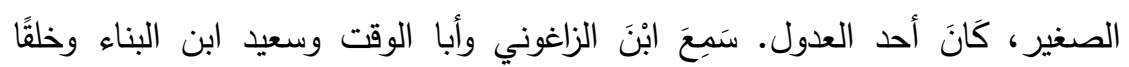

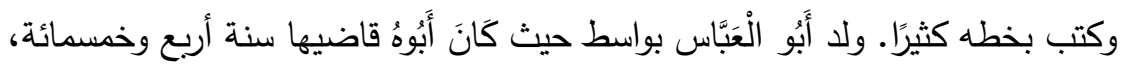

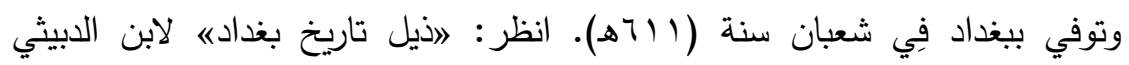
[ $[$ [1 17$]$ 
وخمسـمائة بجاهع القصر الشريف قبل الصـلاة وبعدها، والحمد لله رب العالمين، وصلى الله على نبينا وسلم)؛.

وهي بخط القاضي أبي يعلى كها يدل عليه سياق سهاعه المدون

على طرتها ، وذكره نفسـه بالاسم المجرد ، وذكر سماع ولده أبي القاسـم، وبيانه سنـه، وأول سهاعاته، مها يبعد معاه أن يكون منقولا. والظاهر أن هذا الجزء كان متداولا ببيت أبي يعلى فقد بقي إلى حفيده ابن أبي يعلى الصغير، فصار هو يرويه ويسمعاه للناس، وهو كاتب السهاع الوحيد الذي بخاتمـة النسخة ، والله أعلى. 


الجزء من الفوائد المنتقاة الغرائب ت...

نماذج من النسخة الخطية

وهي على الترتيب ( الغلاف - الوجه الأول - الوجاه الأخير - -

السماع) السماع)

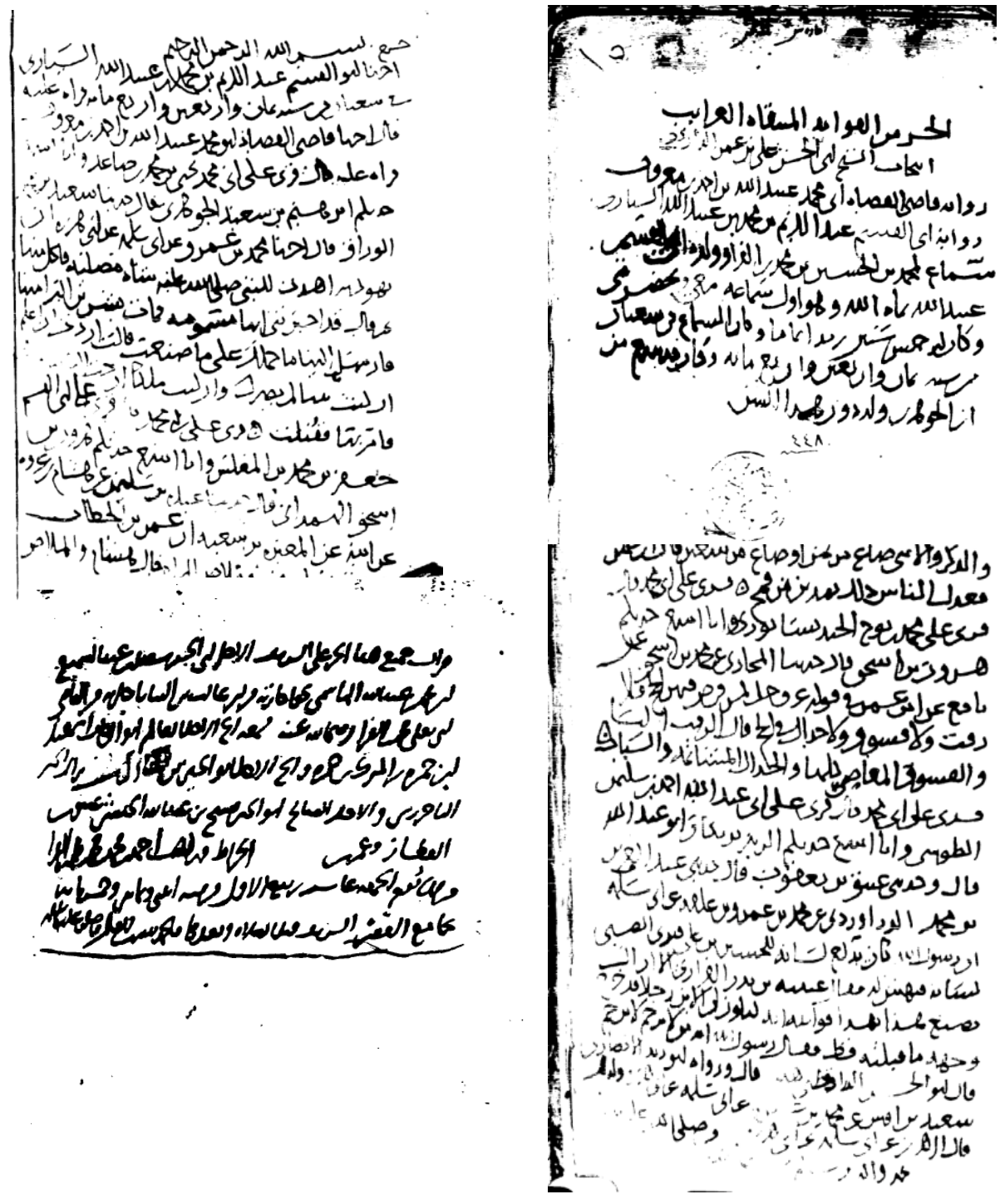

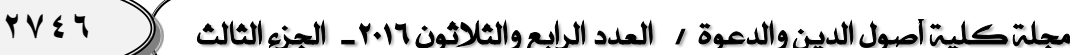


قسم التحمقبق

$$
\text { الجزء من }
$$

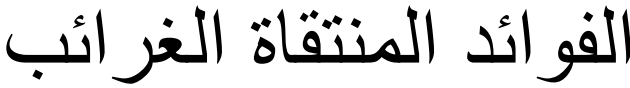

انتخاب الثيخ أبي الحسن علي بن عمر الدارقطني

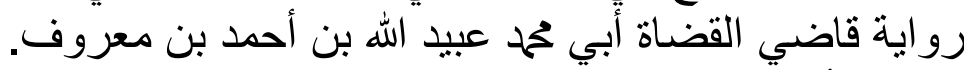

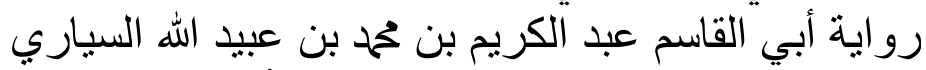

سماع لعحد بن الحسين بن ححم بن الفراء، وولده أبي القاسم عبيد الله نماه الله.

وهو أول سماعه معي وبكضرتي، وكان له خمس سنين زِيَّ إتمامًا، وكان السماع في شعبان من سنة

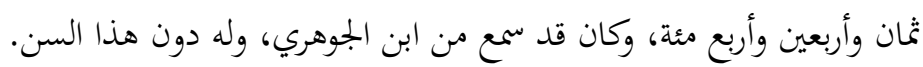




\section{(1)}

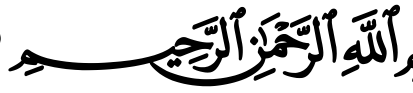

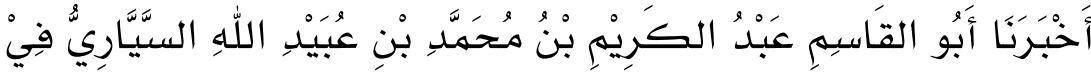

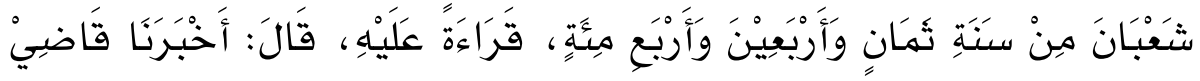

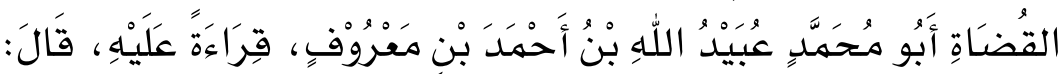

1

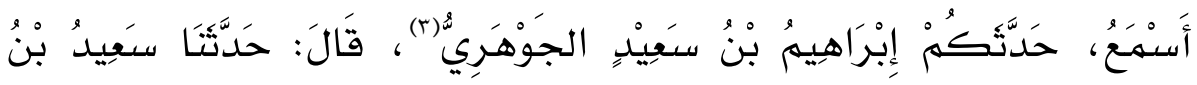

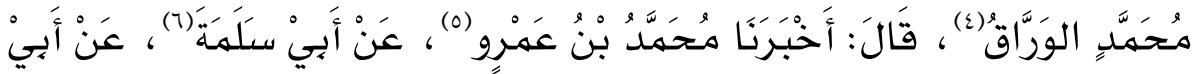

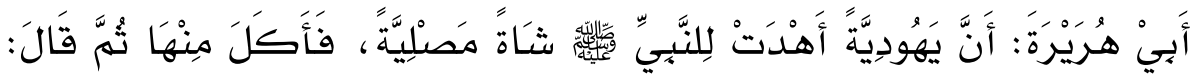

(1) (1) قبالتها بالحاشية اليمنى: (اسمع)؛

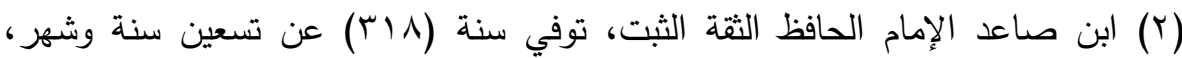

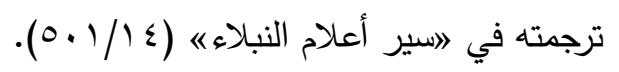

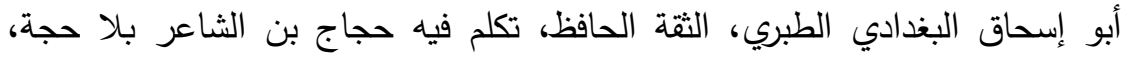

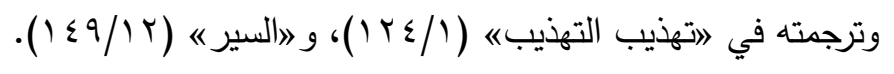

أبو الحسن الكوفي، نزيل بغداد، ضعفه جماعة وقال الدارقطني: (متروكيه، وانظر :

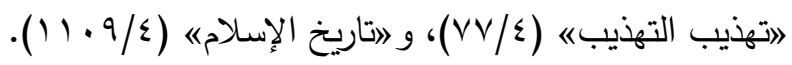

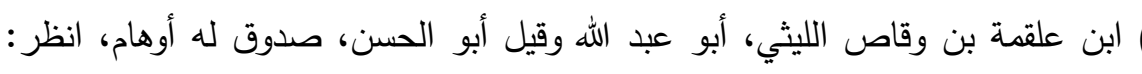

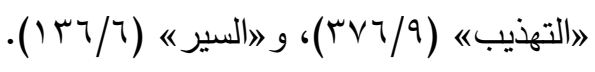

ابن عبد الرحمن بن عوف الزهري الإمام أحد أعلام المدينة ثقة مكثر، وانظر:

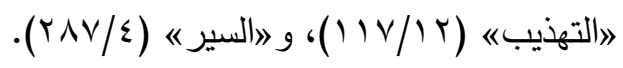




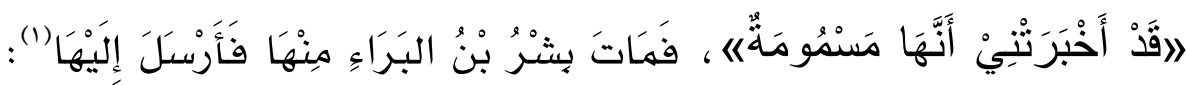

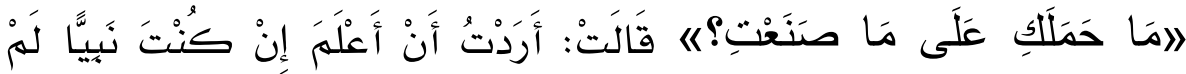

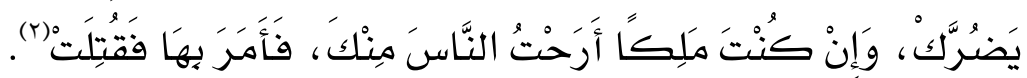

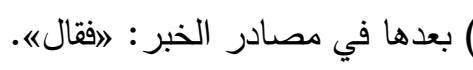

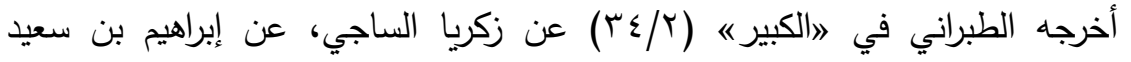

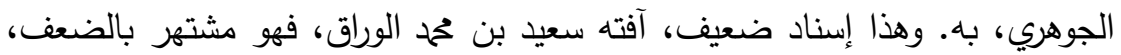

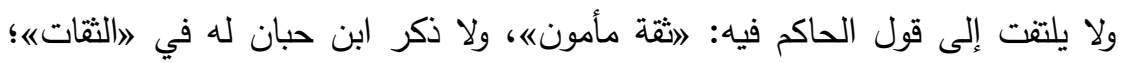

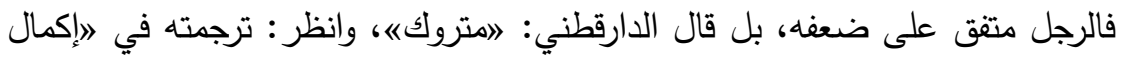

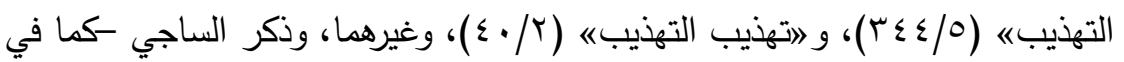

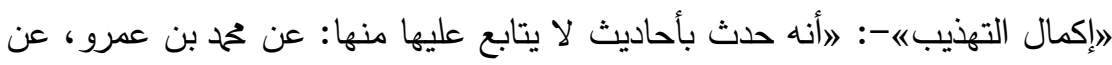

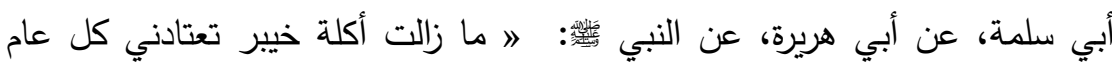

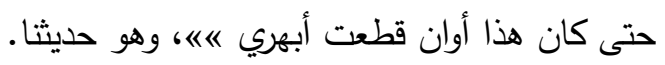
وقد اختلف على محم بن عمرو في هذا الحديث في وصله وإرساله، فرواه موصولا:

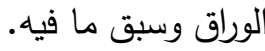
وقد تابع الورَّاقَ على وصله وإسناده: حماد بن سلمة، أخرجه الحاكم في „المستدركه

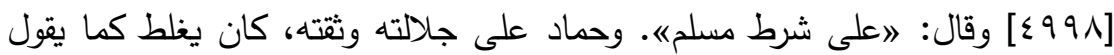

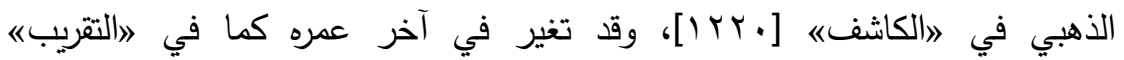
[10.V] وخالفهما: خالد الواسطي، وجعفر بن عون فروياه مرسلا، أخرجه أبو داود [Y (0)؛] من

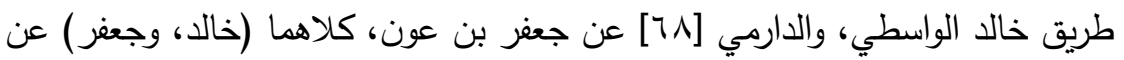
محمد بن عمرو، عن أبي سلمة، مرسلا، ليس فيه ذكر أبي هريرة، وخالد وجعفر أتقن

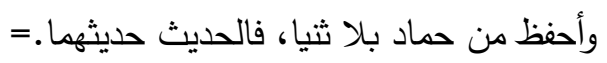




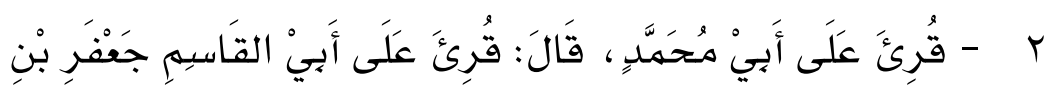

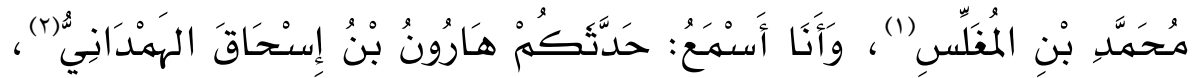

= وقد وقع في رواية ابن الأعرابي للاسنن أبي داود《 موصولا مسندا، ومن طريق ابن الأعرابي رواه القاضي عياض في لالشفاه (1/T (1/) عن أبي علي الغساني، عن أبي

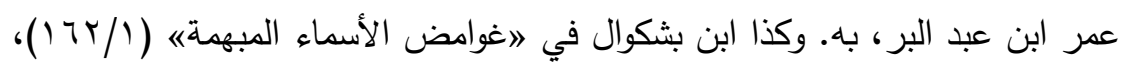

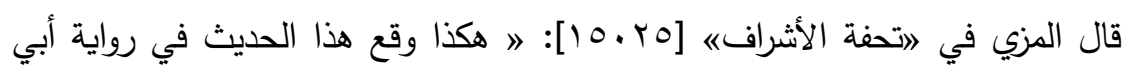
سعيد بن الأعرابي، عن أبي داود، وعند باقي الرواة: 》اعن أبي سلمة؛ أن رسول الله

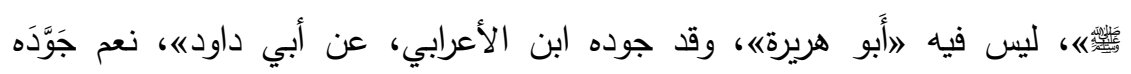
فأفسده، وأبو سعيد ابن الأعرابي على حفظه وإمامته قد كانت له أوهام، كما في لالسان الميزانه [^ov] فالظاهر أن هذا منها، فقد خالفه كل رواة السنن فأرسلوه، وهو

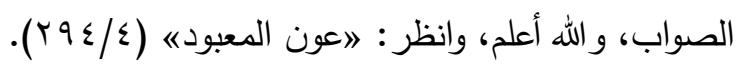

بقي أن الظاهر أن موضع الغرابة في هذا الحديث إنما في رواية الوراق عن ححمد بن عمرو عن أبي سلمة موصولا عن أبي هريرة، وإلا فأصل الحديث صحيح محفوظ مخرج في

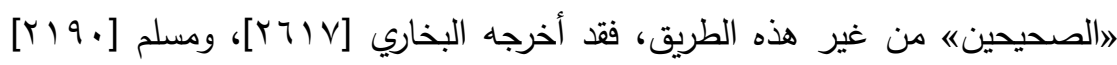
من حديث أنس رضي الله عنه، و الله أعلم.

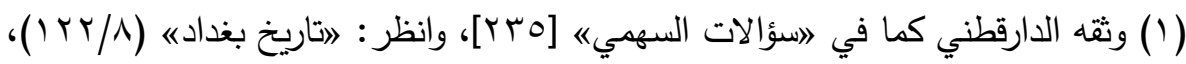

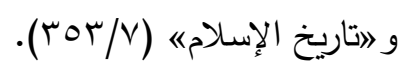

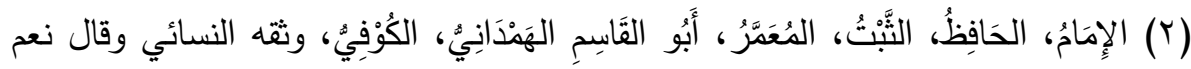
الشيخ كان وهو قليل الحديث، وقال أبو حاتم صدوق، وتبعه عليه ابن حجر في

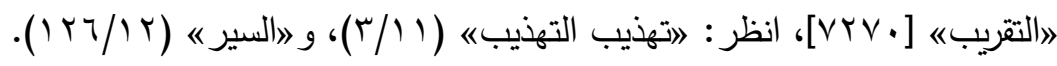

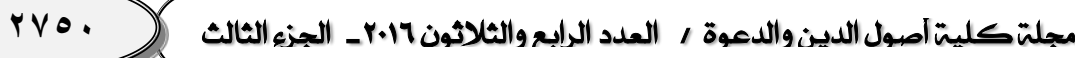




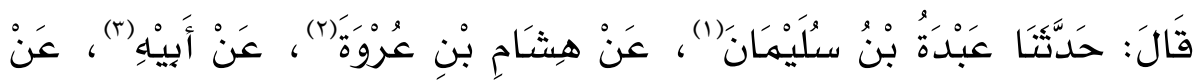

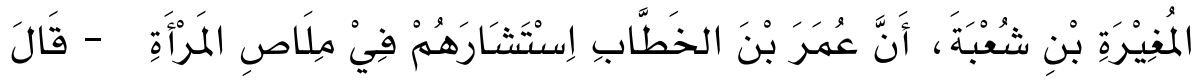

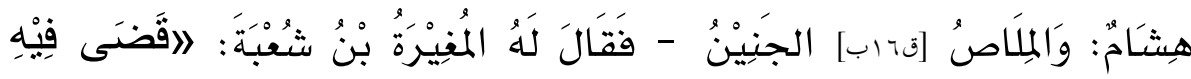

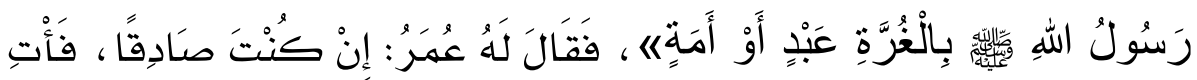

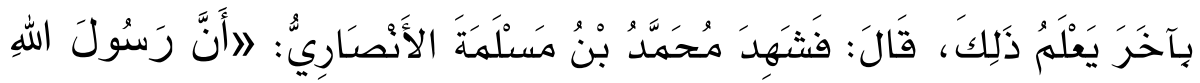

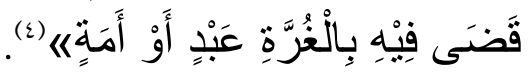

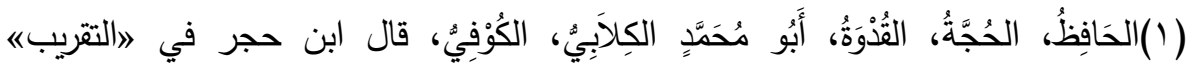

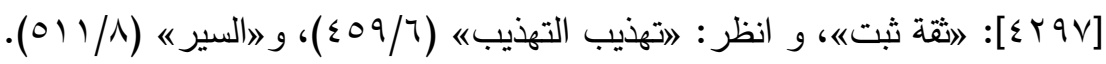

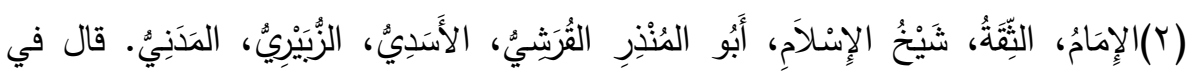

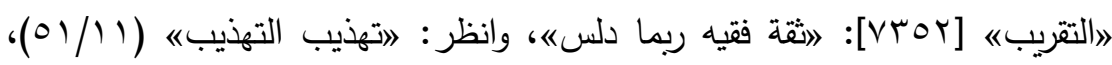

$$
\text { و 》السير 《) (T/ ) }
$$

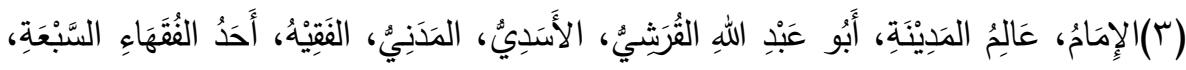

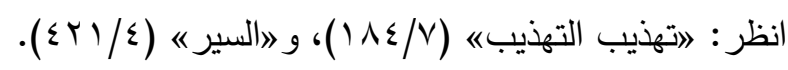

(ء) لم أقف على طريق عبدة عن هشام هذه، إلا عند الدارقطني؛ فقد ذكره معلقا في

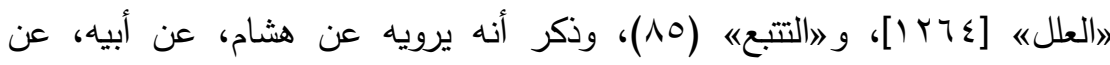
المسور بن مخرمة، عن المغيرة، كرواية وكيع التي عند مسلم، وهذا خلاف ما هنا حيث لم يذكر فيه 》المسور بن مخرمة/ فإن صح ما هنا، ولم يكن سقطا في نسختا؛ فيكون من الفوائد المستغربة، ولذا انتخبه الدارقطني هنا، والله أعلم، وقد أخرج الحديث البخاري [0.97] من طريق وهيب، و[7.97] من طريق عبيد الله بن موسى،

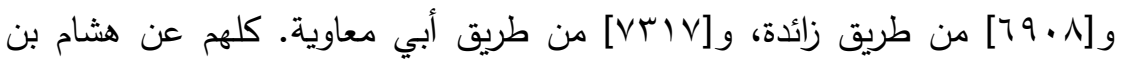

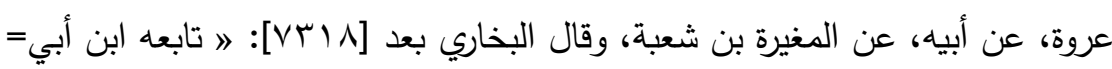

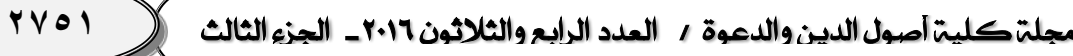




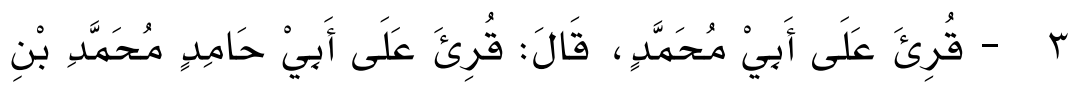

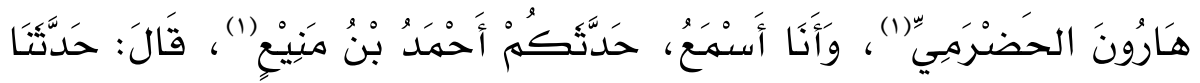

=الزناد، عن أبيه، عن عروة، عن المغيرةه، وقد وصل هذا التعليق: الطبراني في

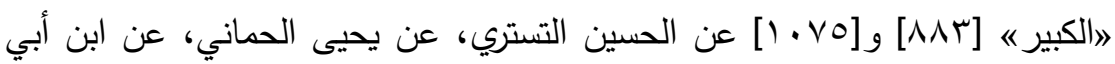
الزناد، به. ووقع في حديث زائدة عند البخاري التصريح بسماع عروة له من المغيرة.

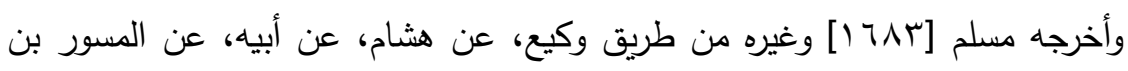
مخرمة، عن المغيرة، فزاد فيه 》المسور بن مخرمة《. وذكر الدارقطني في »العلله أن عبدة بن سليمان، وقيس بن الربيع، وعلي بن غراب، ويزيد بن سنان، قد رووه عن هشام بن عروة كرواية وكيع. قلت: وليس هؤلاء بالأثبات من أصحاب هشام، ولا هم من حفاظهم، عدا وكيعا، وقد خالفهم الثقات الأثبات، فلم يذكروا 》المسور ش، فالقول قولهم. قال الدارقطني في 》التبع): 》أخرج مسلم حديث وكيع، عن هشام، عن أبيه، عن المسور: 》أن عمر استثار في إملاص المرأة|، وهذا وهم، وخالفه أصحاب هشام:

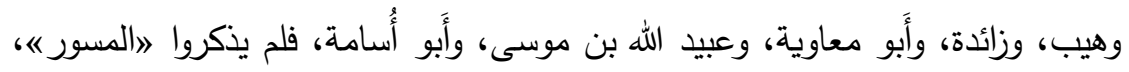
وهو الصواب، وفي حديث زائدة، عن هشام، عن أبيه سمع المغيرة، وكذلك قال أَبو الزناد، عن عروة، عن المغيرة، ولم يخرج مسلم غير حديث وكيع وهو وهم، وأخرج البخاري أحاديث من خالف وأتى بالصوابع،

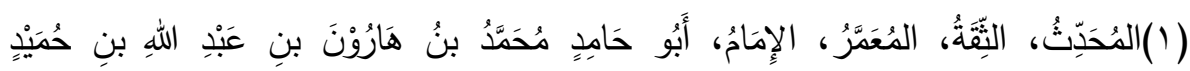

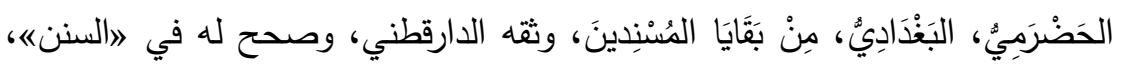

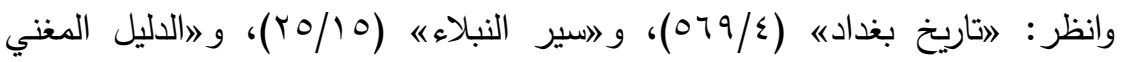

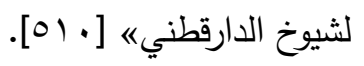




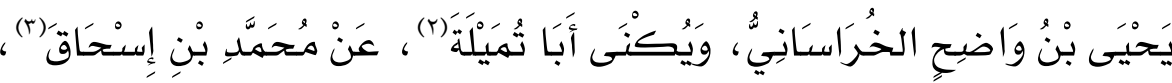

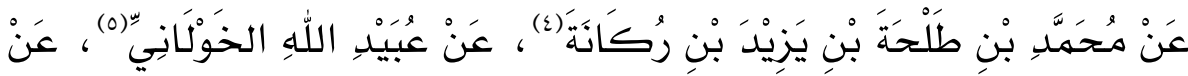

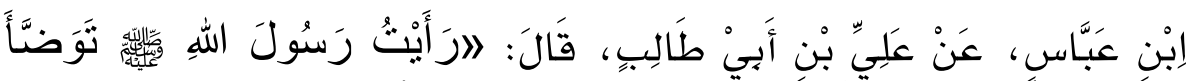

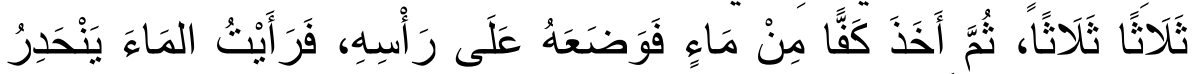

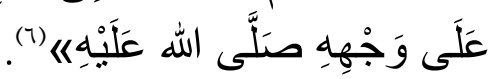

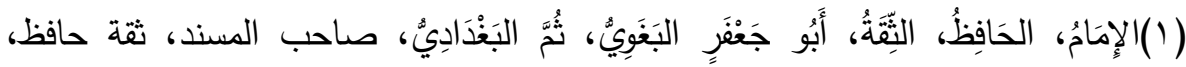

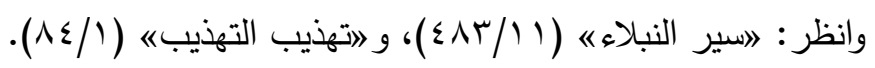

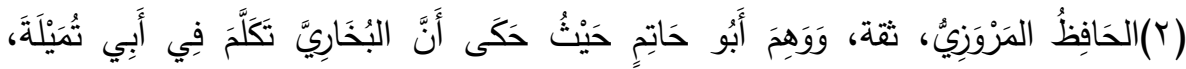

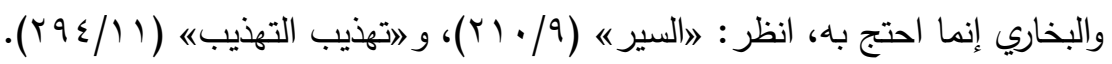

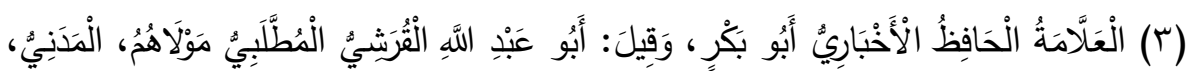

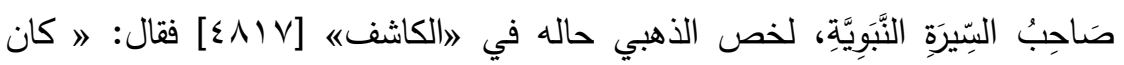
صدوقا، دن بحور العلم، وله غرائب في سعة ما روى تستكر ، واختلف في الاحتجاج به، وحديثه حسن، وقد صححه جماعة/، وانظر : 》السير 《/ (T/)، و اتهذيب

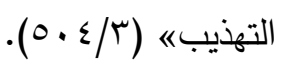

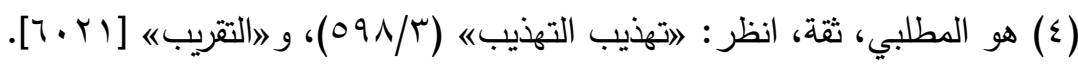
(0) هو عبيد الله بن الأسود، ويقال: ابن الأسد الخولاني ربيب أم المؤمنين ميمونة رضي الله عنها، قال ابن حجر: \المراد بقوله: ربيب ميمونة، أنها ربته، فقيل: كان مولاها، لا

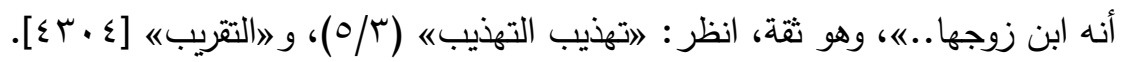

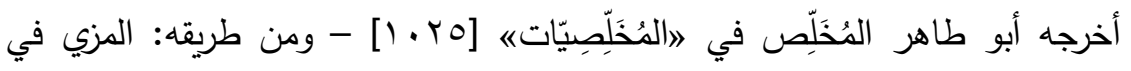

$$
\text { "التهذيبه (9/9/9)- عن أبي القاسم البغوي، عن جده أحمد بن منيع. }
$$

= وأخرجه إسحاق بن راهويه في 》(مسندهي -كما في 》المختارة) للضياء [9 . 7]- كلاهما

$$
\text { (ابن منيع، وابن راهويه) عن يحيى بن واضتح، به. }
$$




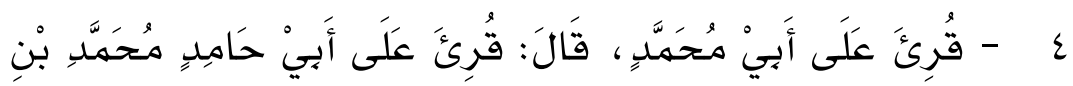

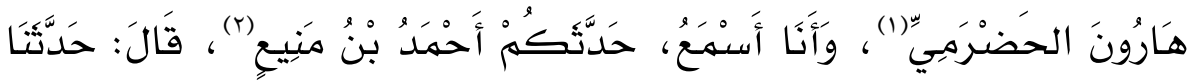

وهو اختصار لحديث طويل في صفة الوضوء؛ أخرجه أبو داود في 》السنن《 [l V V]

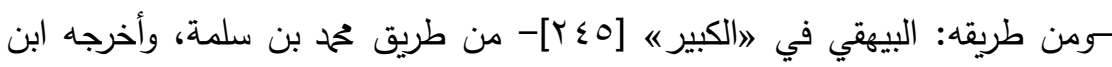

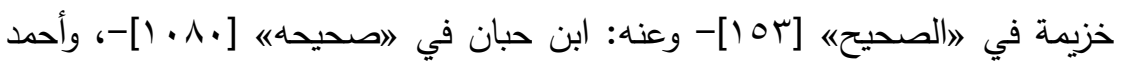

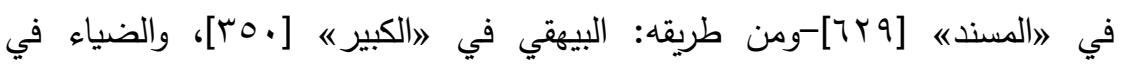

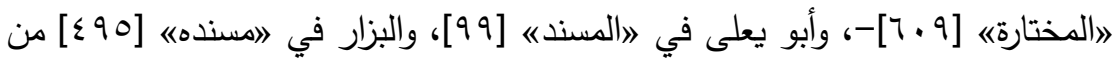
طريق إسماعيل ابن عُلِيّة. وأخرجه البزار [§9 ؛] من طريق عبد الرحمن المحاربي. وأخرجه الطحاوي في لثرح معاني الآثار ش [M II] من طريق عبدة بن سليمان. أربعتهم (عحمد بن سلمة، وإسماعيل، والمحاربي، وعبدة) عن ححم بن إسحاق، به.

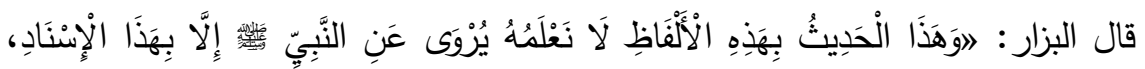

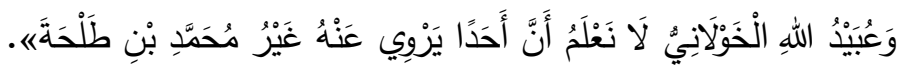

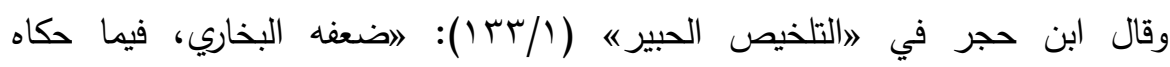
الترمذي《«

ووجه الغرابة أن أبا تميلة يحيى بن واضح وهو ثقة حافظ، قد رواه هكذا مختصرا بالمعنى، على خلاف ما رواه أصحاب محمد بن إسحاق المذكورين، وعامتهم ثقات

$$
\begin{aligned}
& \text { أثبات، فرواية يحيى من الفوائد المستغربة، و الله أعلم. } \\
& \text { (1) سبقت ترجمته في الحديث السابق [r]. } \\
& \text { (Y) سبقت ترجمته في الحديث السابق [r]. }
\end{aligned}
$$

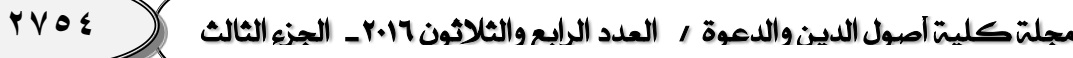




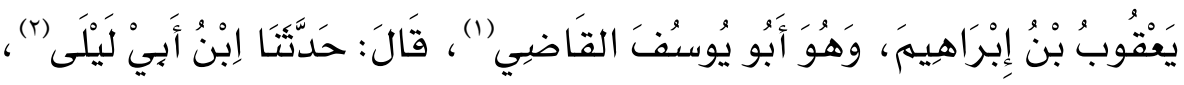

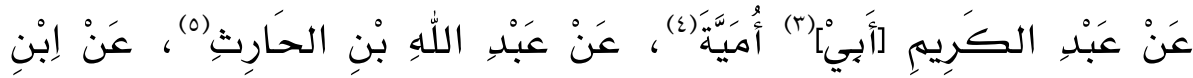

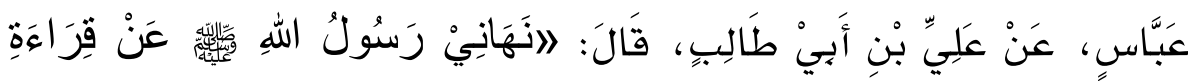

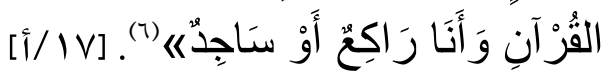

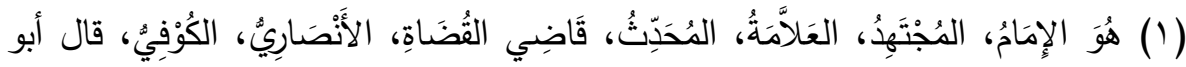
حاتم: 》صدوق《، وقال النسائي: 》اثقة)، وهو أمثل أصحاب أبي حنيفة رحمه الله

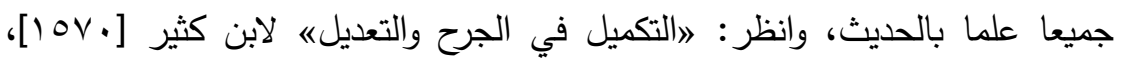

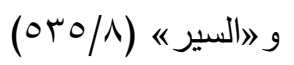

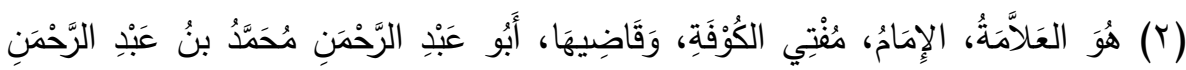

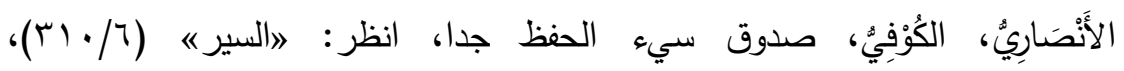

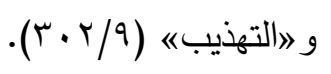

(r) في الأصل: 》ابن أبي" وليس بشيء، كما في جميع مصادر ترجمته.

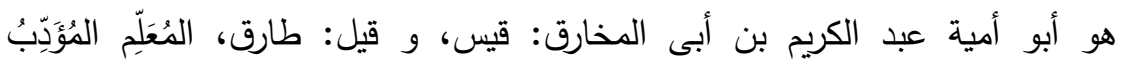

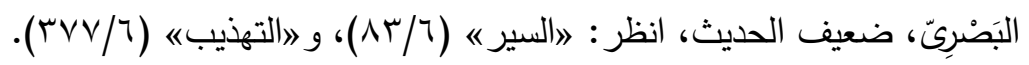

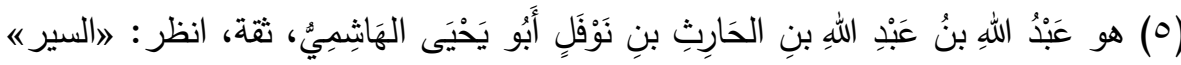

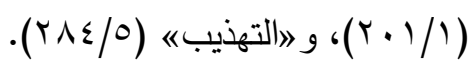

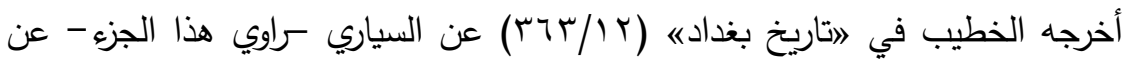

$$
\text { ابن معروف، به. }
$$

وأخرجه البزار في 》امسنده《 [00؛] من طريق عيسى بن المختار، وأخرجه عبد الله بن

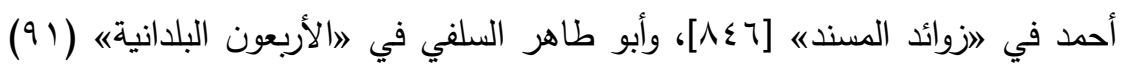

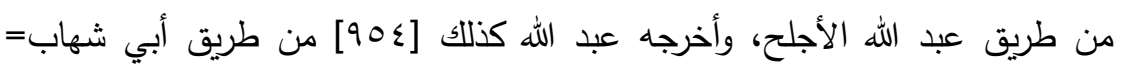

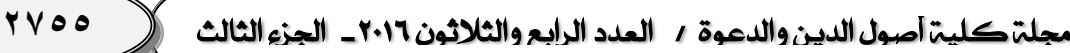


=الحناط، ثلاثتهر عن ابن أبي ليلى، به. زاد في طريق الأجلح: 》عن لباس القسي،

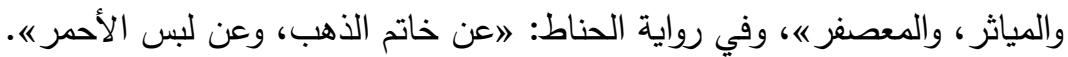

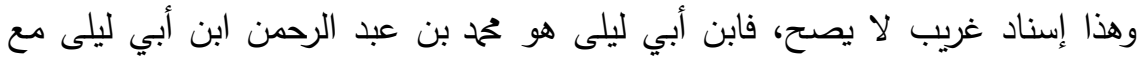

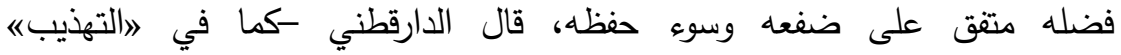
(T/M/T/T)

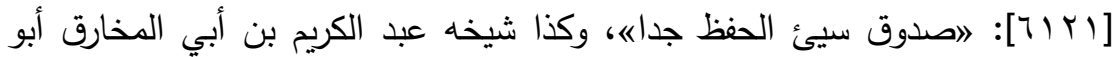

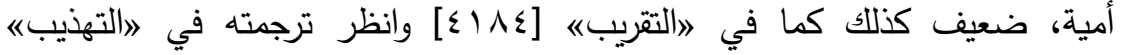

$$
\cdot(T \cdot r / T)
$$

والحديث مشهور من حديث ابن عباس عن علي رضي الله عنهم من طريق آخر، ومع

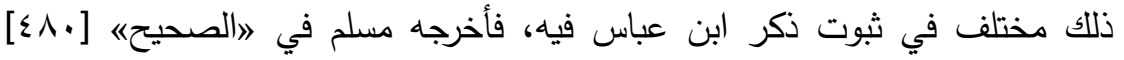

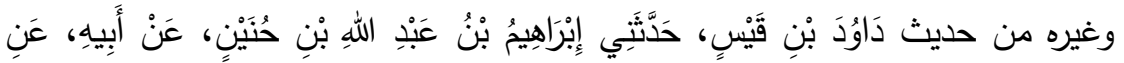

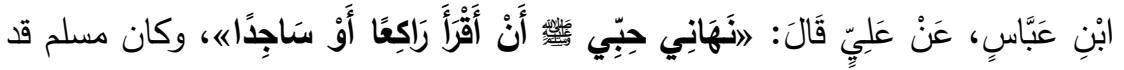

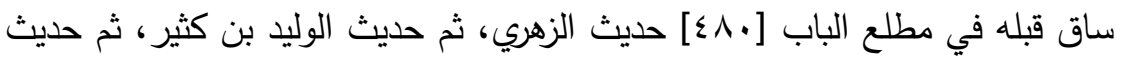

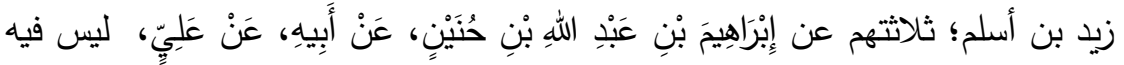
ذكر 》ابن عباس《، ثم ساق مسلم الخلاف في ذللك عقب حديث داود المذكور ، وساقه

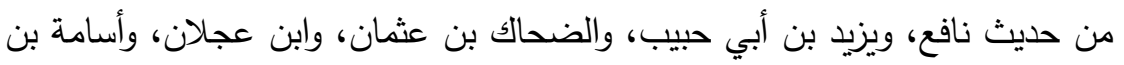

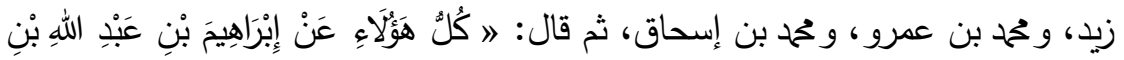

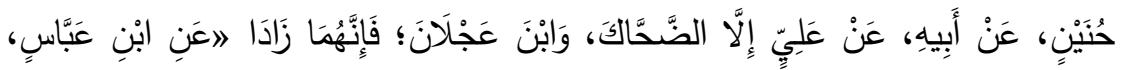

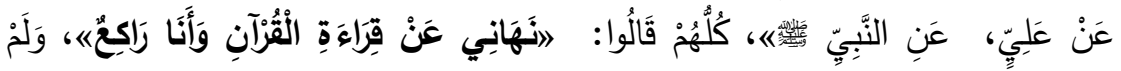

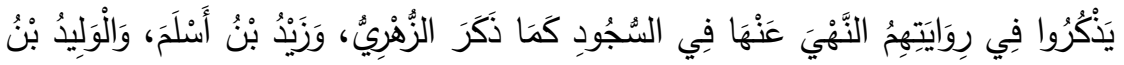

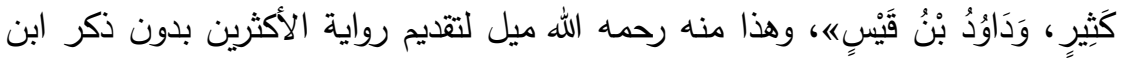

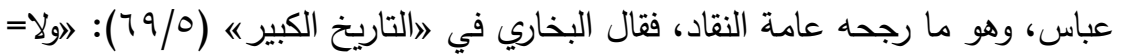

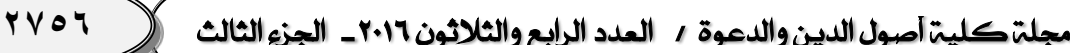




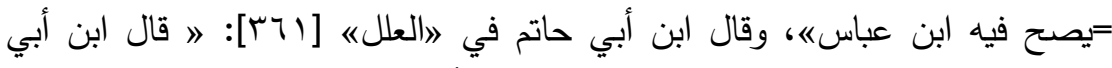

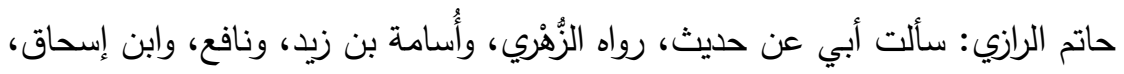

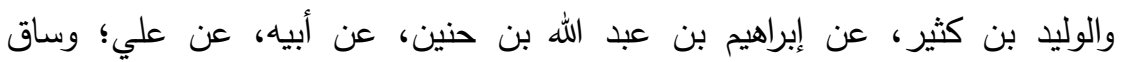

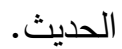

ورواه الضحاك بن عثمان، وداود بن قيس الفراء، وابن عجلان، عن إبراهيم بن عبد الله

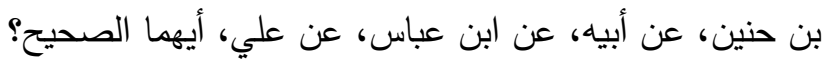

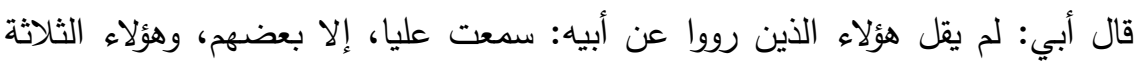
مستورون، والزيادة مقبولة من ثقة، وابن عجلان ثقة، والضحاك بن عثمان ليس

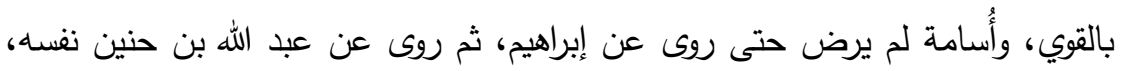

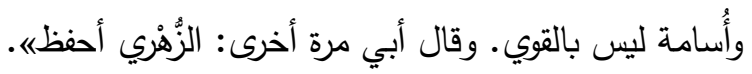

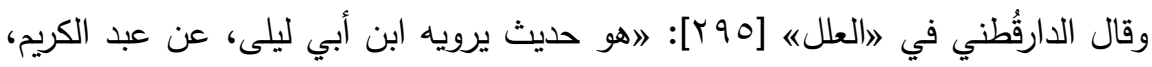

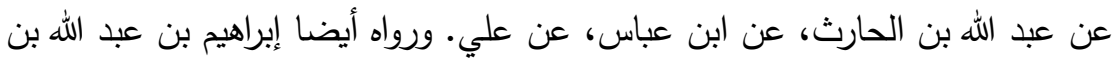

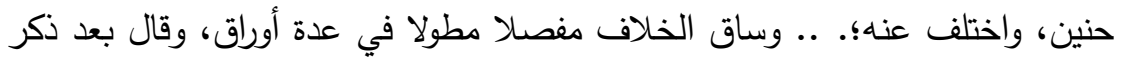
من ذكر ابن عباس: اوخالفهم جماعة أكثر منهم عددا، فرووه عن إبراهيم بن عبد الله،

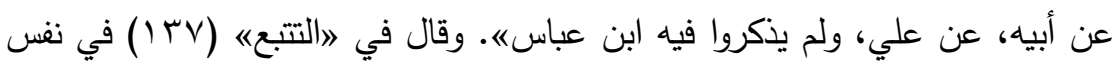

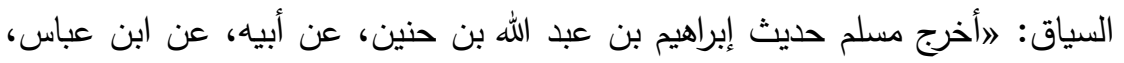

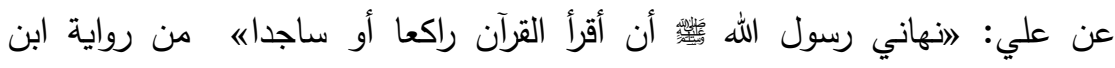

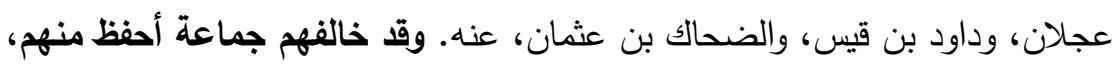

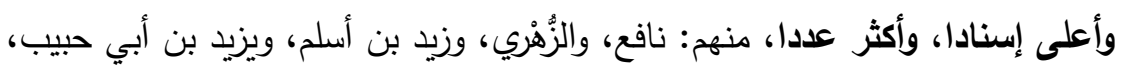

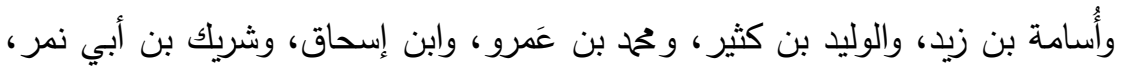

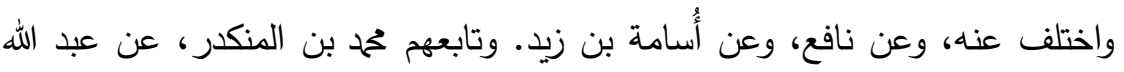

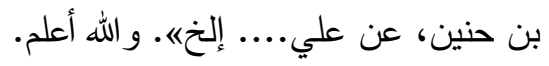

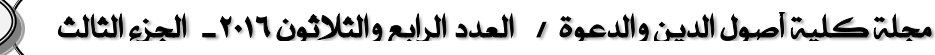




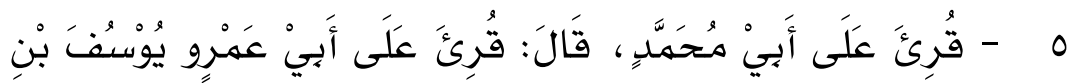

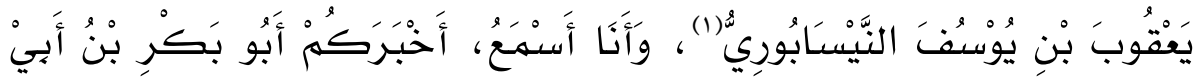

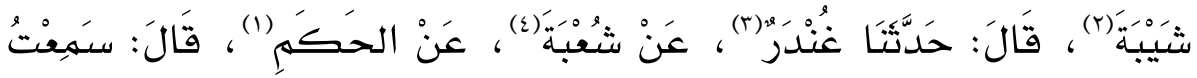

(1) قال الخطيب: 》كان ضعيفا《، وقال أبو علي النيسابوري: 》 ما رأيتُ فِي رحلتي فِي

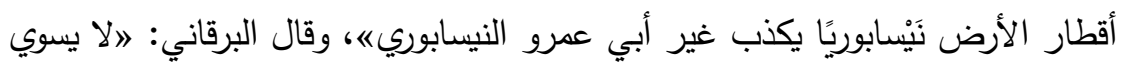
شيئاه، وروايته هنا عن أبي بكر ابن أبي شيبة مما اتهم فيها، فقد قال الخطيب: "

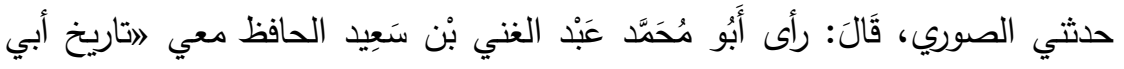

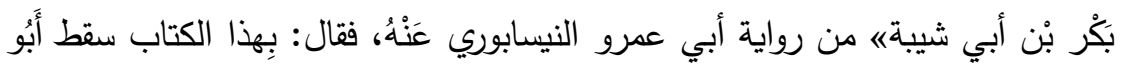

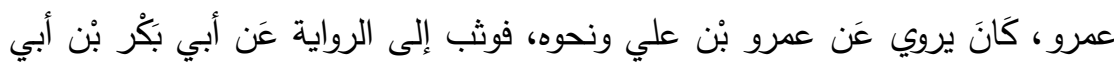

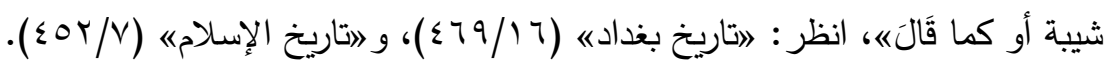

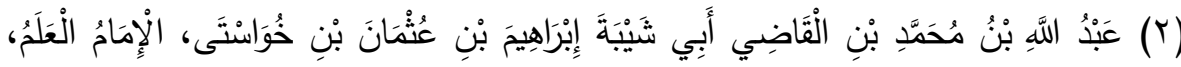

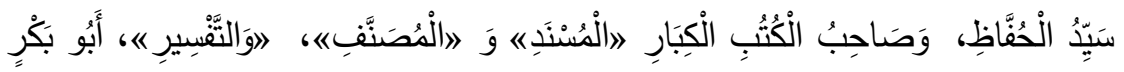

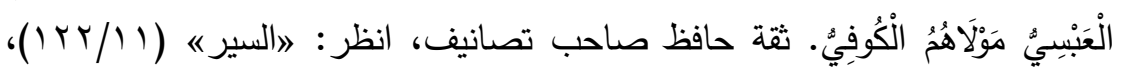

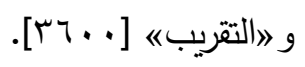

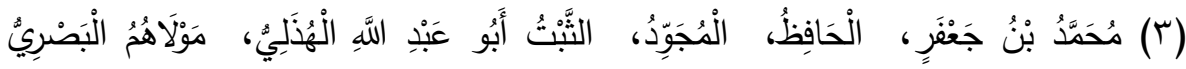

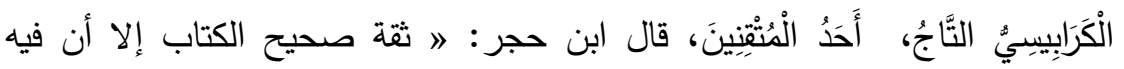

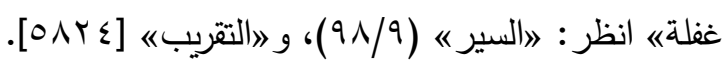

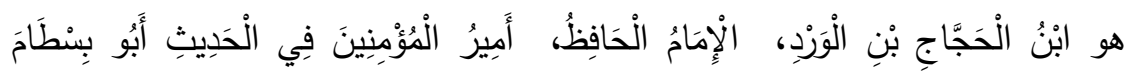

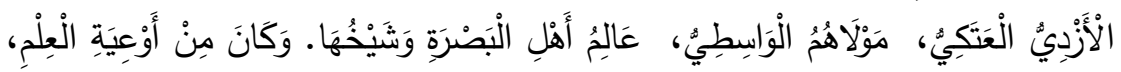

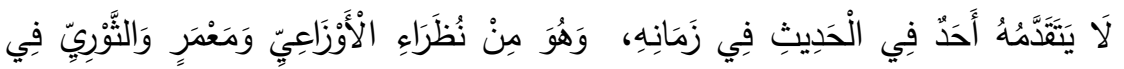

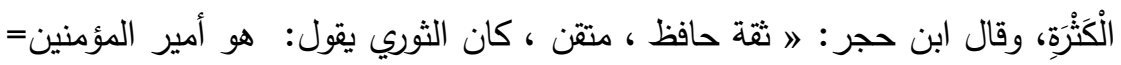




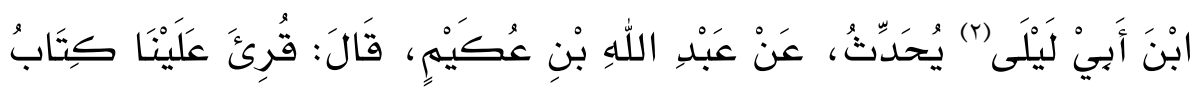

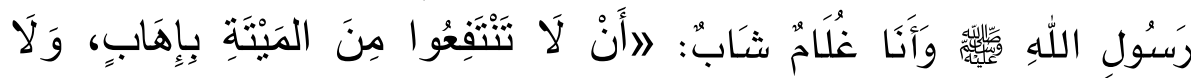

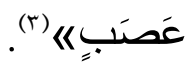

=في الحديث، وهو أول من فتش بالعراق عن الرجال وذب عن السنة ، وكان عابداه،

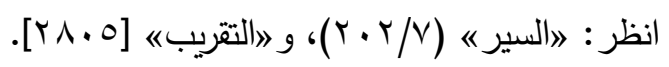

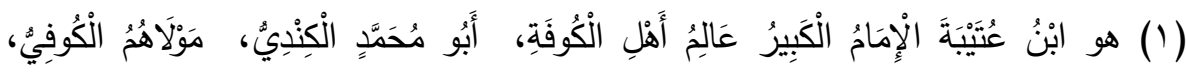

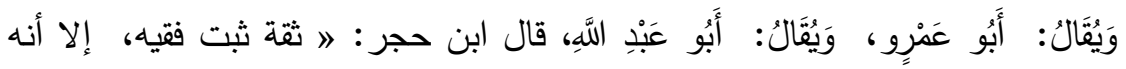

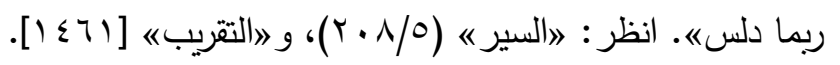

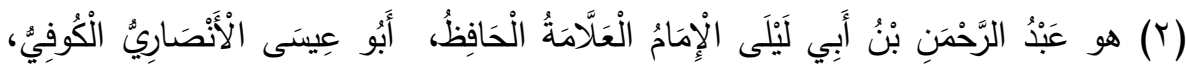

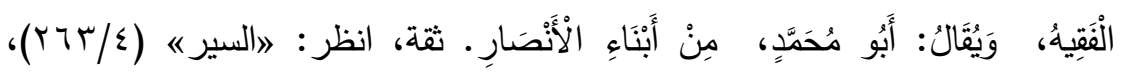

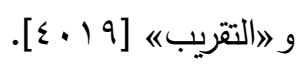

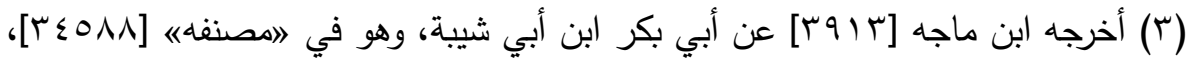

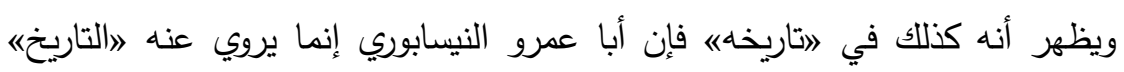

$$
\text { واتهم بسببه، وانظر ترجمته قبل قليل. }
$$

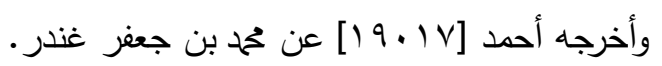

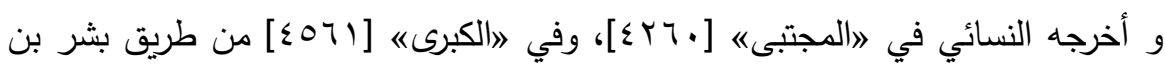

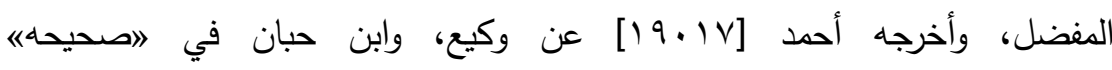

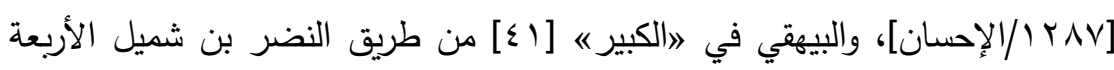

$$
\text { (غندر - بشر -وكيع- النضر ) عن شعبة. }
$$

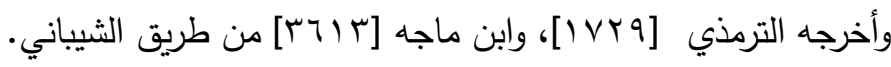

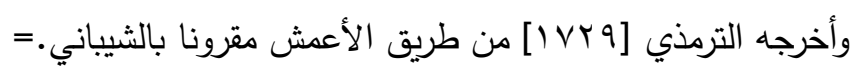

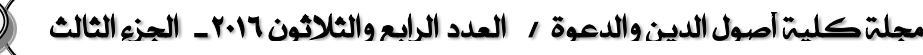




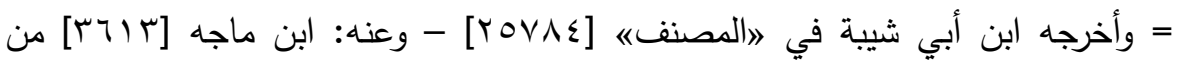
طريق منصور •

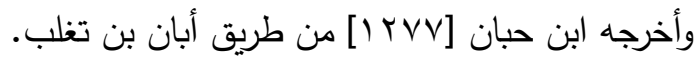

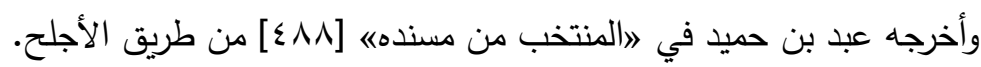

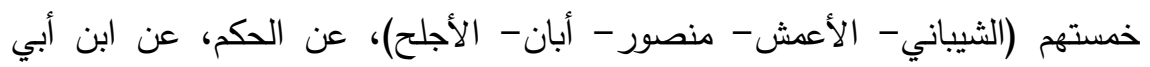
ليلى، عن عبد الله بن عكيم. وللحديث طرق أخرى متكاثرة، وقد وقع في إسناده اختلاف ففي بعضها: عن عبد الله بن

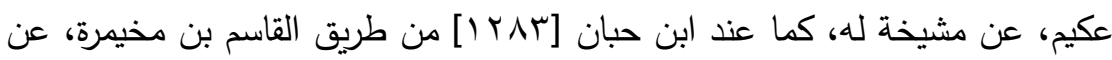
الحكم.

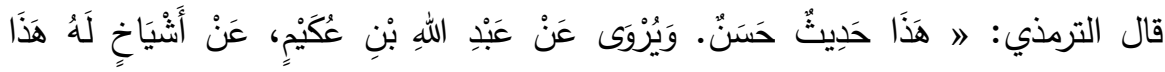
الْحَدِيثُ.

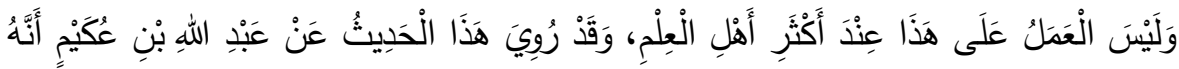

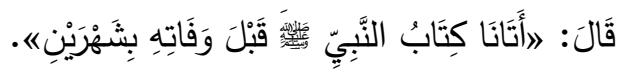

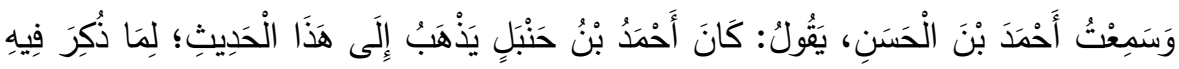

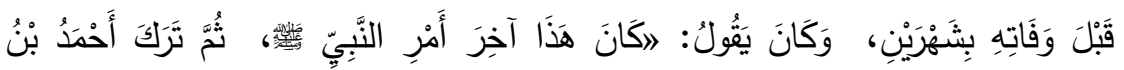

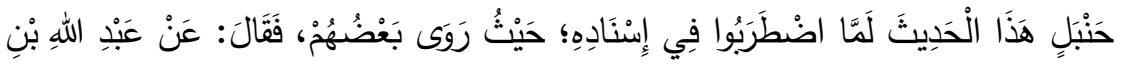

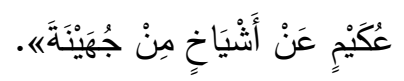
ونقل قول الترمذي ونقله عن أحد الحافظ ابن حجر في الالفتحه)، ثم قال

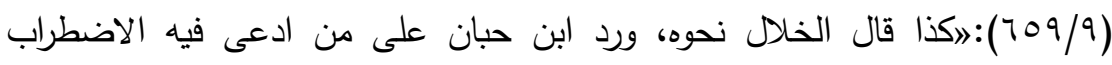

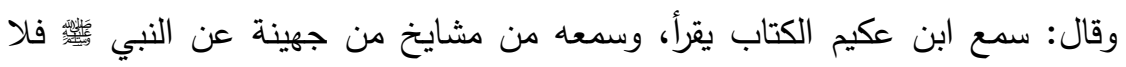

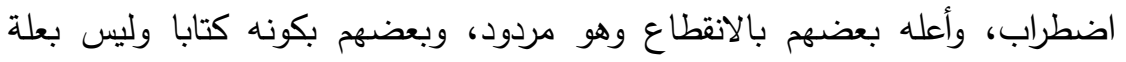

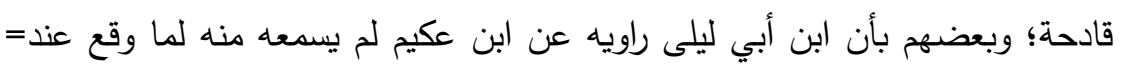

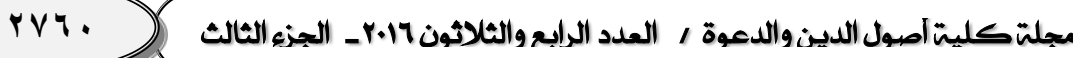


1

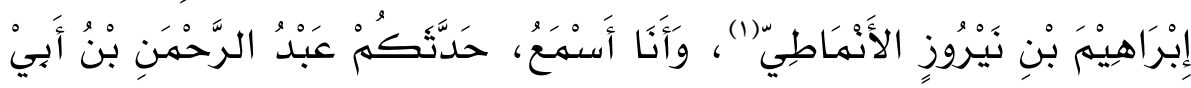

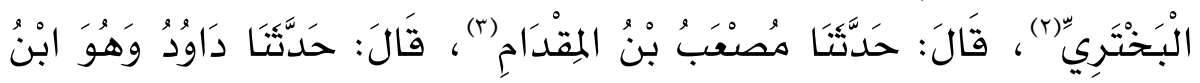

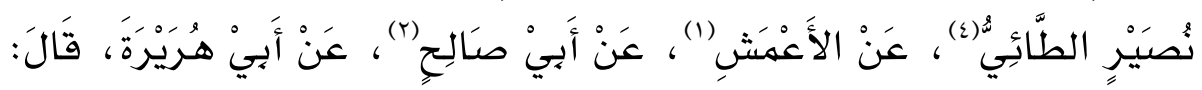

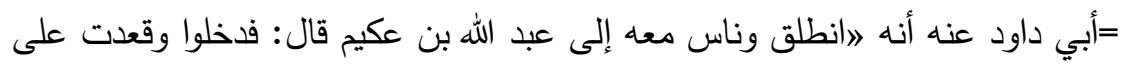

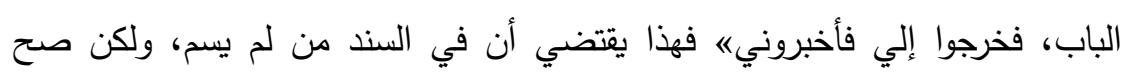
تصريح عبد الرحمن بن أبي ليلى بسماعه من ابن عكيم فلا أثر لهذه العلة أيضا،

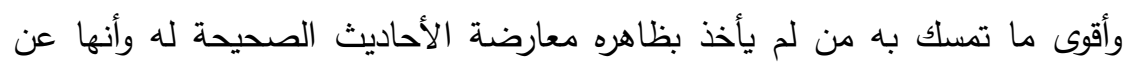

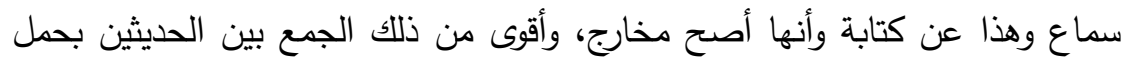

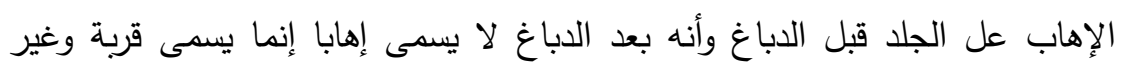

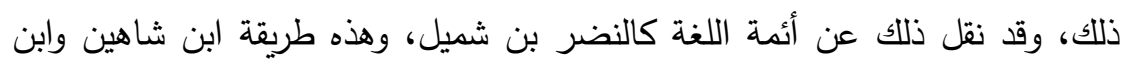

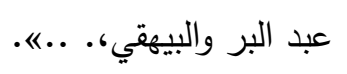

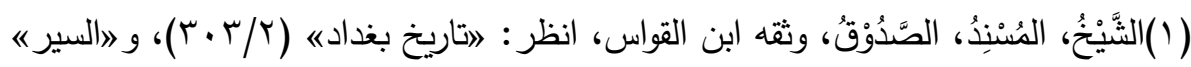

$$
\cdot(\wedge / 10)
$$

هو عبد الرحمن بن زُبَّان، أبو عليّ بن أبي البَخْتَرِيّ الطّائيّ، ترجمه الخطيب في

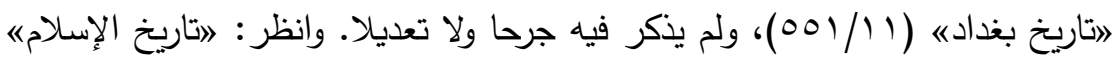

$$
\text { (1) (1) (1) (1) (1) }
$$

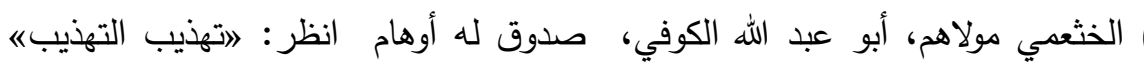

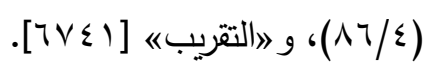

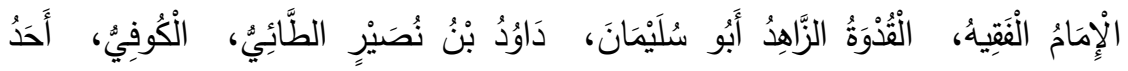

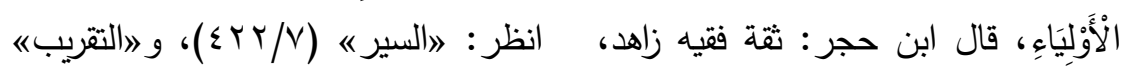

[I INO]

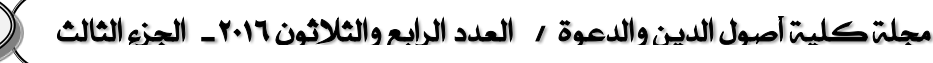




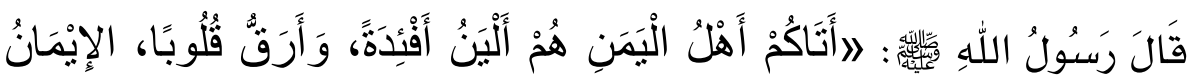

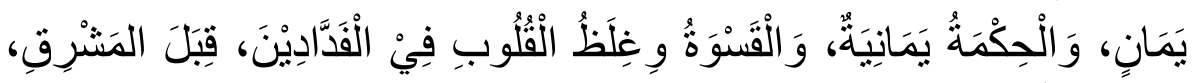

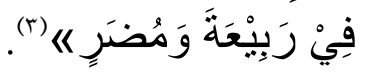

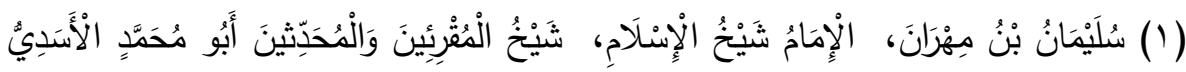

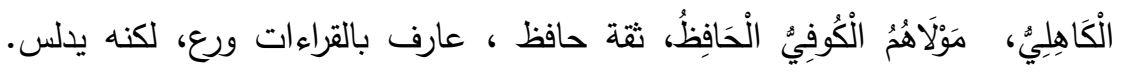

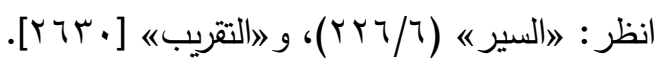

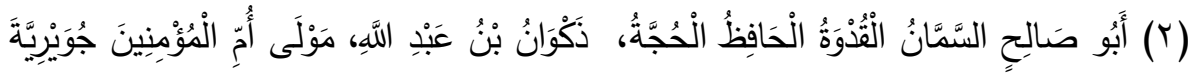

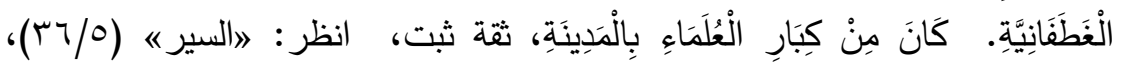

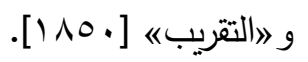

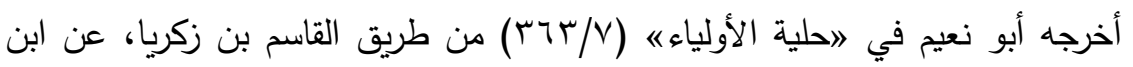

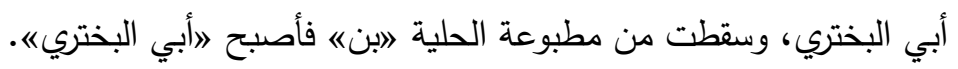

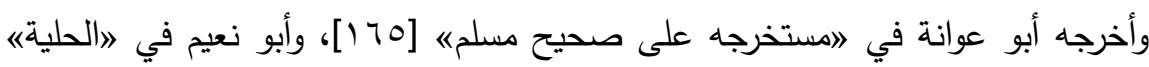
(r/V)

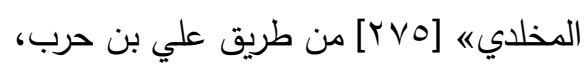

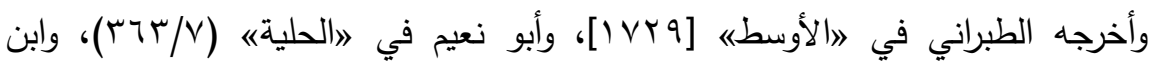

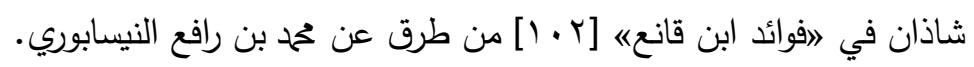

$$
\text { ثلاثتهم (ابن أبي البختري، ابن حرب، ابن رافع) عن مصعب بن بن المقدام. }
$$

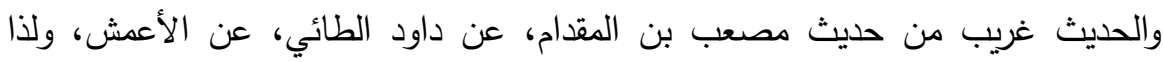

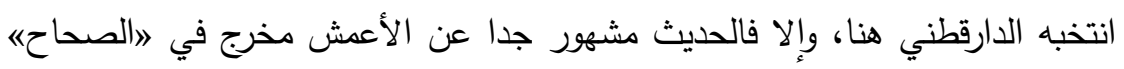

$$
\text { لكن من غير طريق داود. }
$$

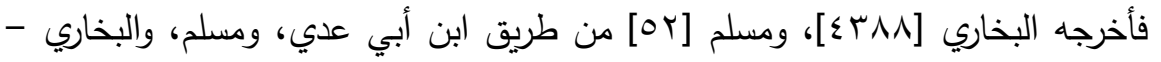

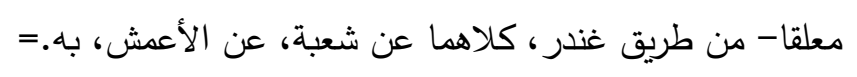




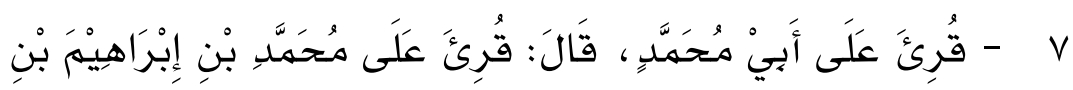

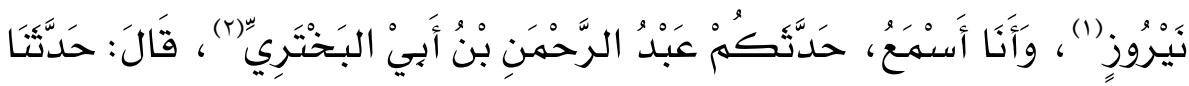

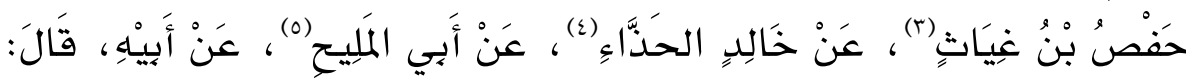

= وأخرجه مسلم كذلك من طريق أبي معاوية محمد بن خازم الضرير، وكذا من طريق جرير كاري

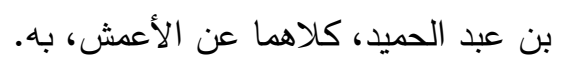

وهو أشد اشتهارا من حديث أبي هريرة، إذ يرويه عنه جماعة كثيرون عامتهم في الصحاح بهاه

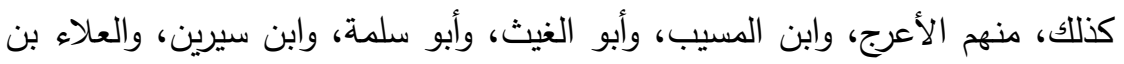

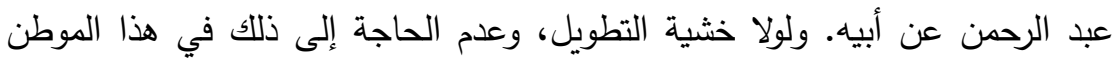
لخرجت أحاديثهم، فهي مجموعة مسودة عندي. و الله أعلم.

$$
\text { سبقت ترجمته في الحديث السابق [ب]. }
$$

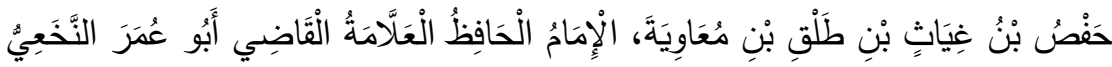

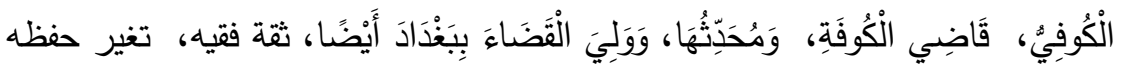

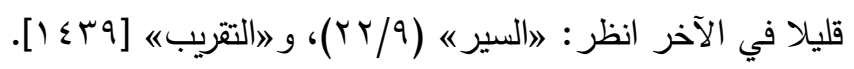

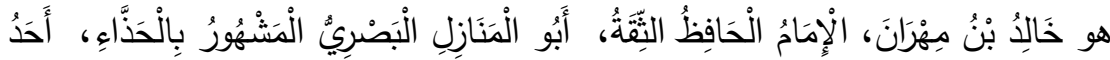

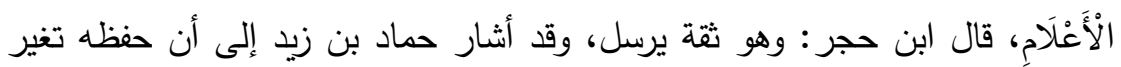

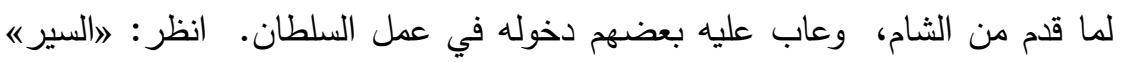

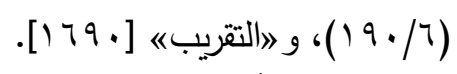

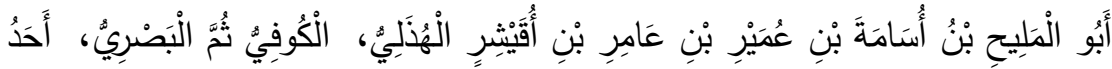

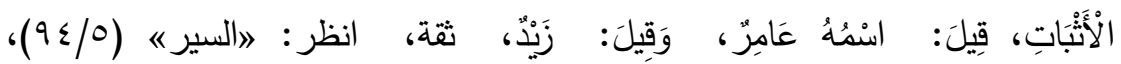

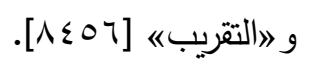

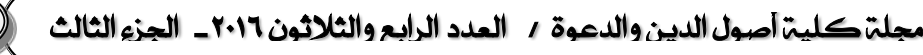




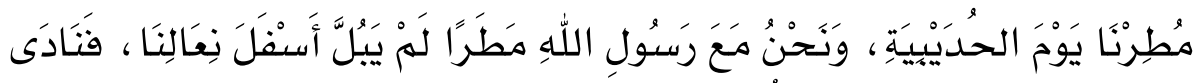

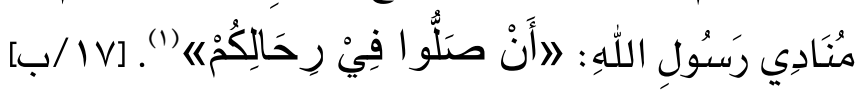

(1) أخرجه البيهقي في 》الكبير [ [ • 10] من طريق عبد الوهاب بن عطاء، وأخرجه ابن

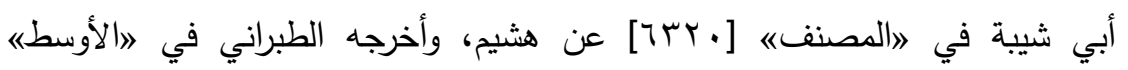

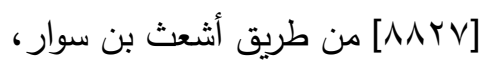

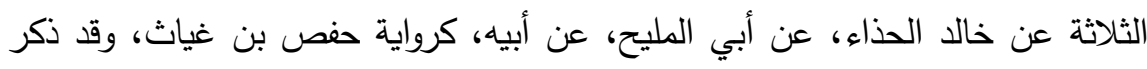

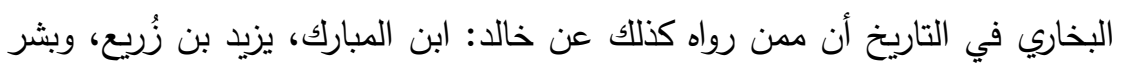
بن المفضل.

وقد خالفهم أكثر أصحاب خالد الحذاء، فرووه عن الحذاء، عن أبي قلابة، عن أبي

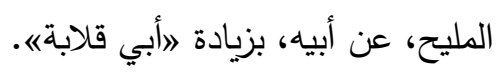

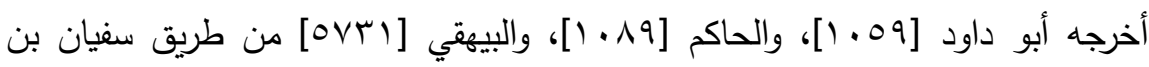
حبيب.

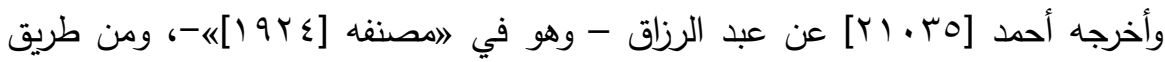

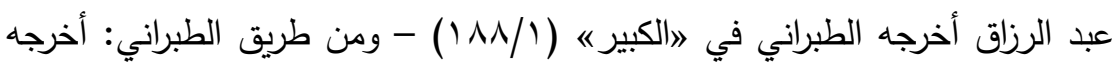

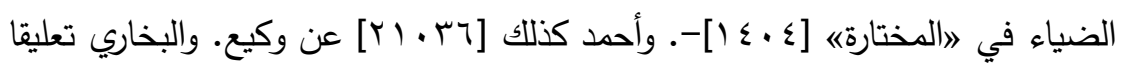

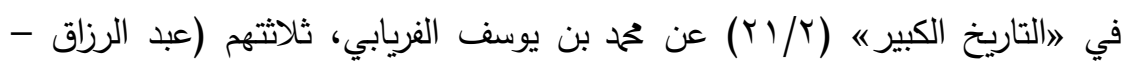

$$
\text { وكيع - الفريابي) عن الثوري. }
$$

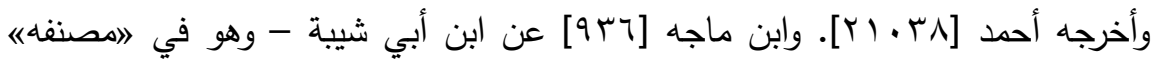

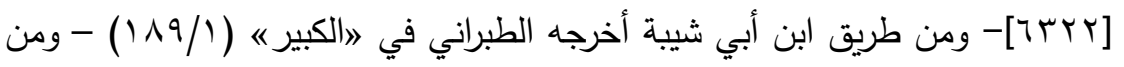

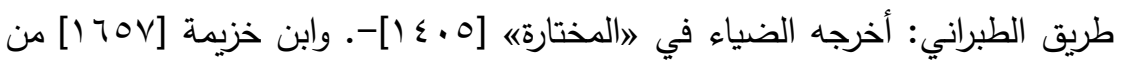
طريق مؤمل بن هشام، وزياد بن أيوب. أربعتهم (أحمد- ابن أبي شيبة- مؤمل - زياد) عن إسماعيل بن علية.=

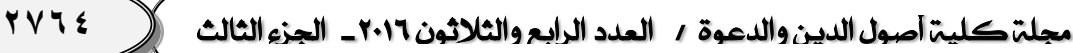




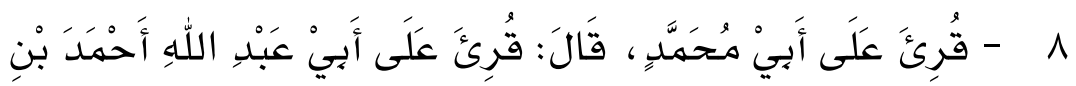

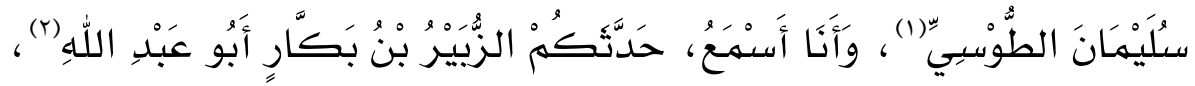

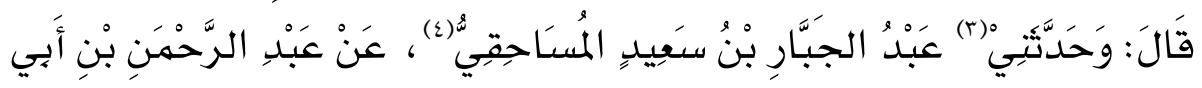

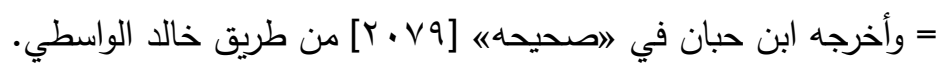
الأربعة (ابن حبيب- الثوري- ابن علية- الواسطي) عن خالد الحذاء، عن أبي قلابة، عن أبي المليح، عن أبيه. وزاد البخاري في 》التاريخه (Y/Y) مع هؤلاء: شعبة بن الحجاج. والظاهر أن هذا الوجه الذي فيه 》أبو قلابةه هو الأرجح، فرواته أثبت وأحفظ، وأضبط لحديث خالا الحذاء، وهو الذي رواه أصحاب الأصول المشتهرة، بخلاف الوجه الأول فإنما يخرجه أصحاب الفوائد والغرائب، ولعله لذلك انتقاه الدارقطني هنا من حديث ابن معروف، و الله أعلم. هو أحمد بن سليمان بن داود، أبو عبد الله الطُّسيّ، قال الخطيب: كان صدوقا، وكان

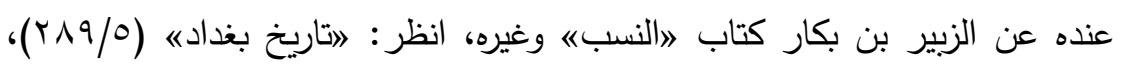

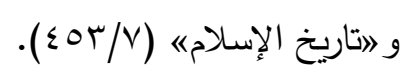

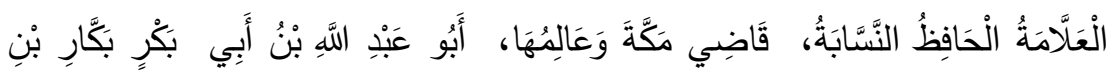

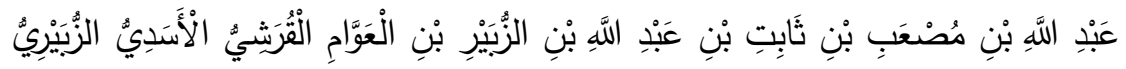

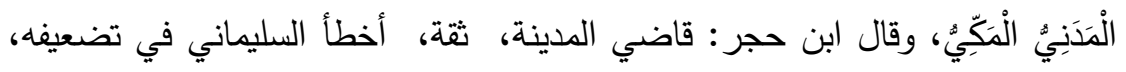

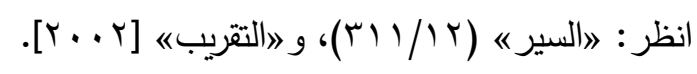

كذا بالأصل، وقائل "وحدثني" هو الزبير بن بكار، والعطف قد يكون على إسناد

$$
\text { سابق عنده. }
$$

عبد الجبار بن سعيد بن سليمان بن نوفل بن مُساحق المساحقي، قال العقيلي: له

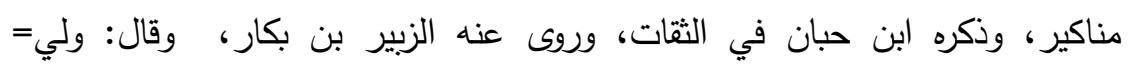

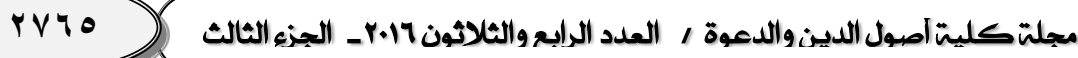




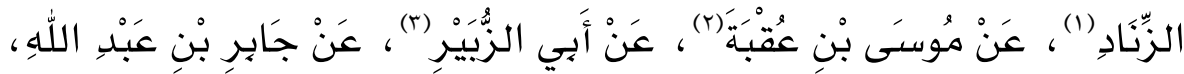

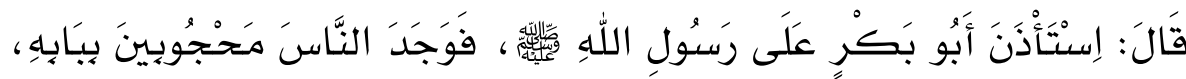

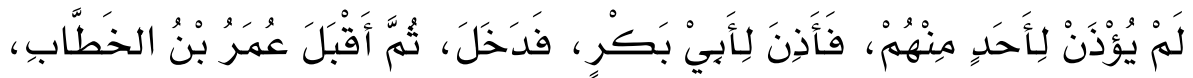

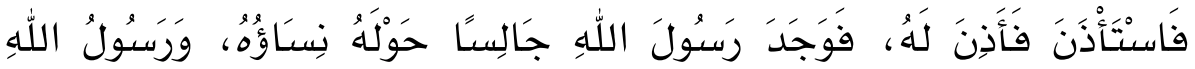

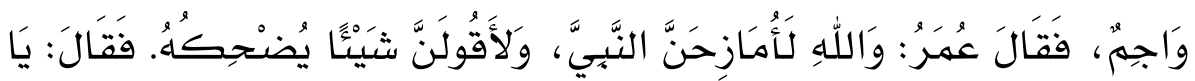

=أبوه قضاء المدينة وولي هو إمرة المدينة مرة بعد مرة ثم ولي قضاءها للمأمون وكان

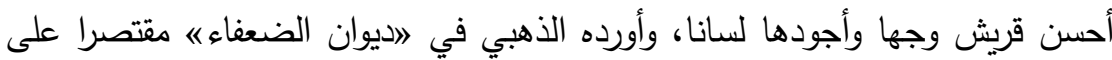

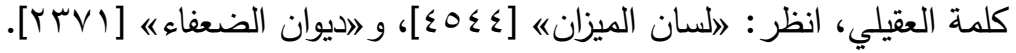

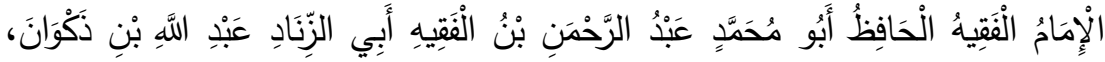

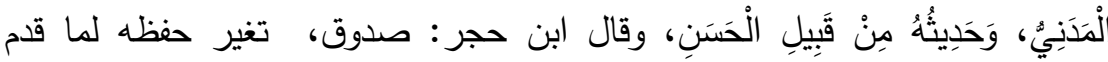

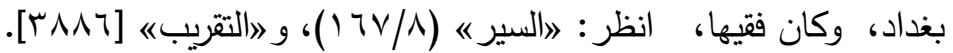

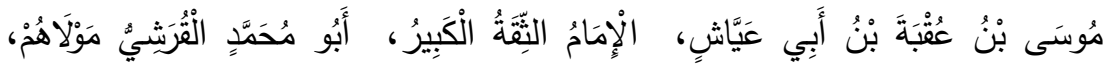

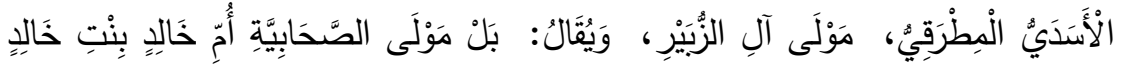

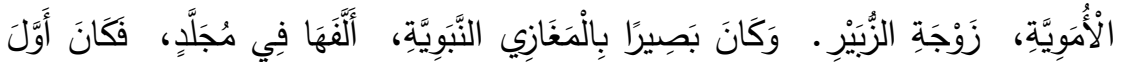

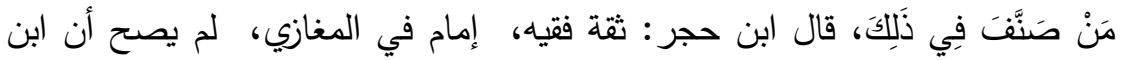

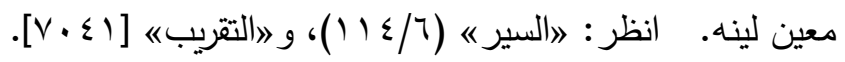

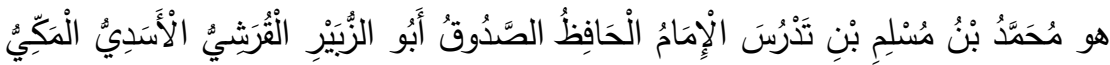

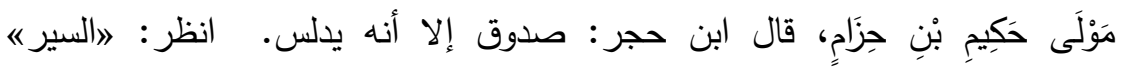
( 


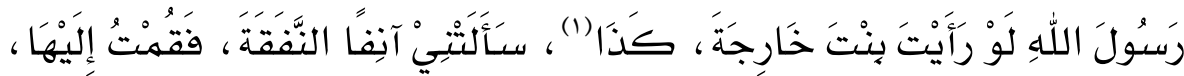

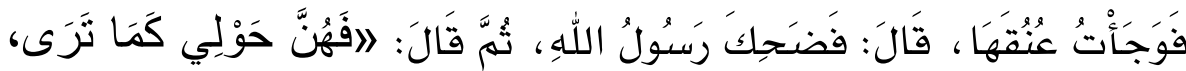

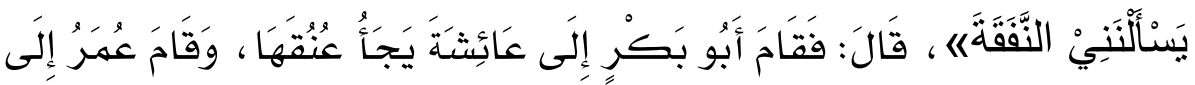

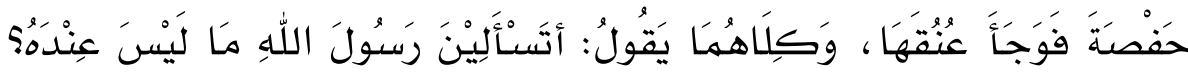

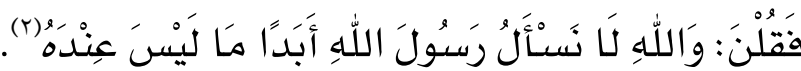

( (1) لعلها كذللك 》كذاه، وكأن المقصود بها استثكال كون بنت خارجة زوجة عمر ، إذا قيل

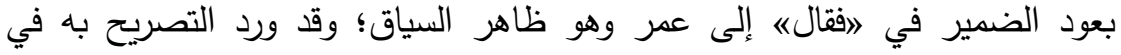
بعض الروايات، حيث لا يعرف لعمر في ذلك الحين زوجة بهذا الاسم، وإنما المعروف

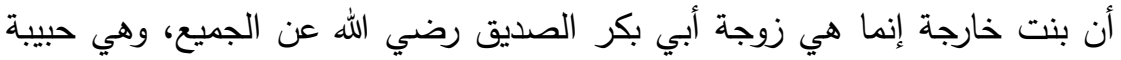

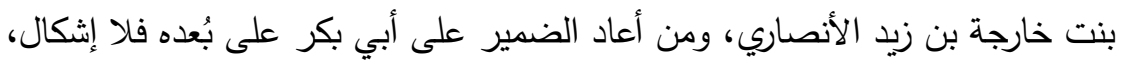
و الله أعلد.

لم أقف عليه بهذا الإسناد في غير هذا الموضع، وهذا إسناد غريب من حديث موسى

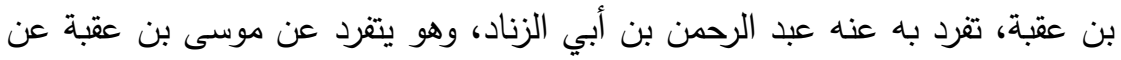

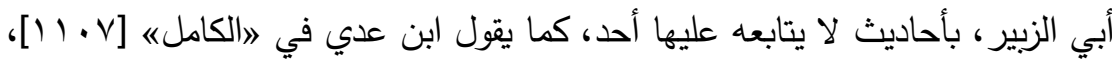
وليس عبد الرحمن بالثبت الذي يتحمل مثل هذا، وإنما هو صدوق تغير حفظه، كما

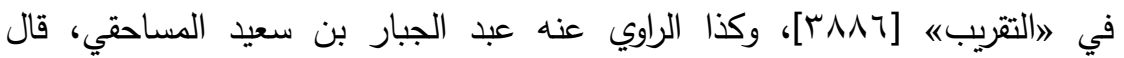

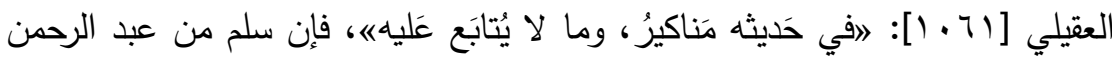

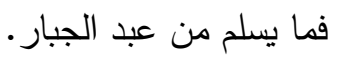
والحديث محفوظ من حديث أبي الزبير عن جابر، ولكن من غير هذا الطريق، فقد أخرجه

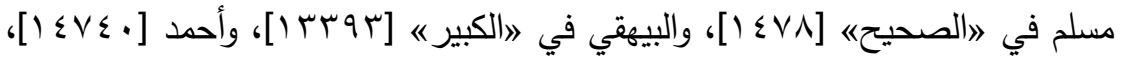

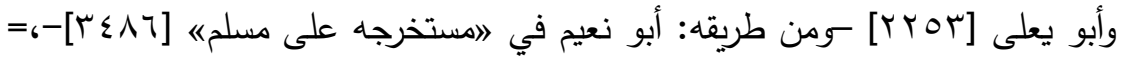




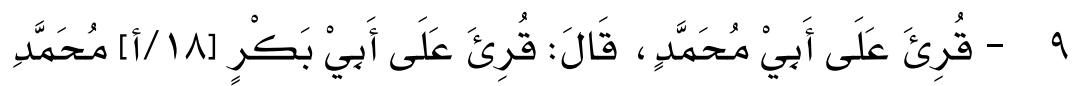

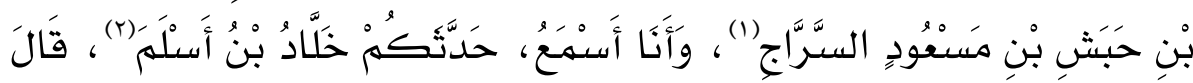

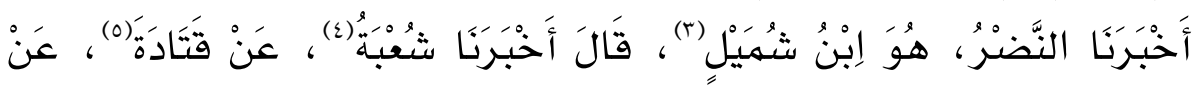

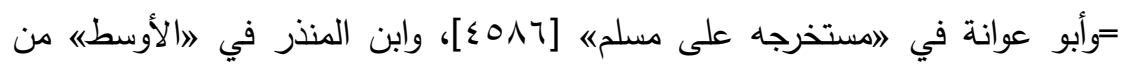

$$
\text { طرق عن روح بن عبادة. }
$$

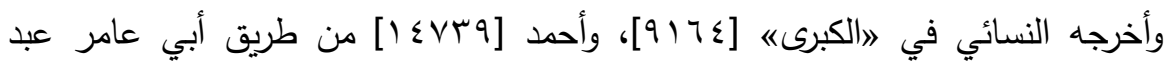

$$
\text { الملك بم عمرو. }
$$

كلاهما (روح وأبو عامر) عن زكريا بن إسحاق.

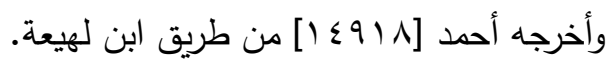

كلاهما (زكريا وابن لهيعة) عن أبي الزبير، عن جابر رضي الله عنه.

قال الخطيب 》اروى عنه ابن بشران وابن معروف أحاديث مستقيمةه، وقال الذهبي:

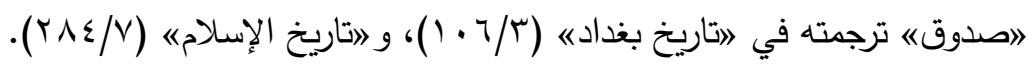

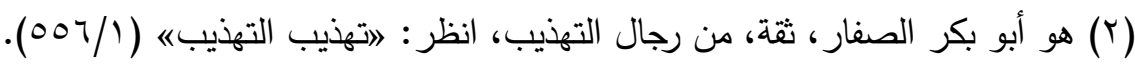

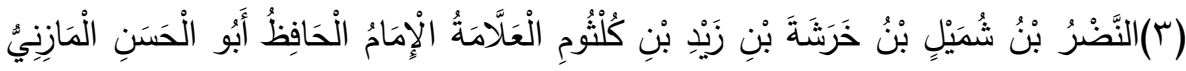

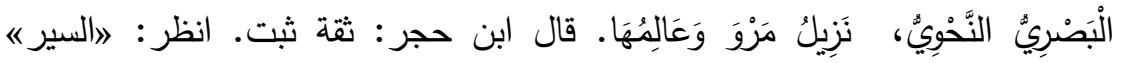

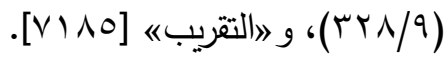

$$
\begin{aligned}
& \text { سبقت ترجمته في الحديث [0]. }
\end{aligned}
$$

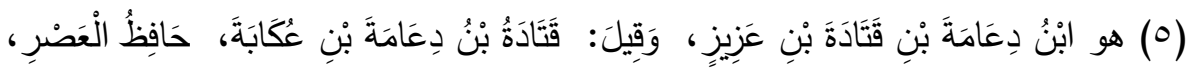

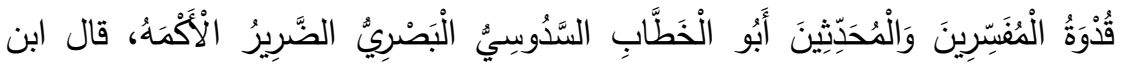

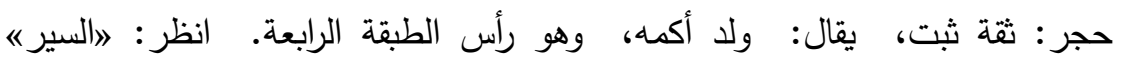

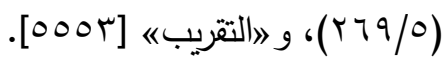

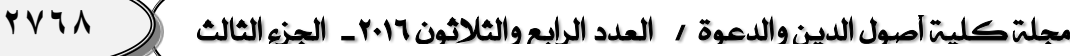




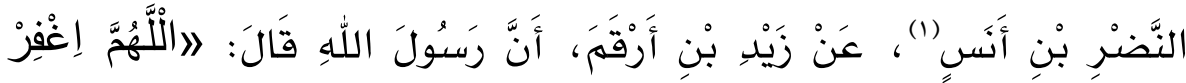

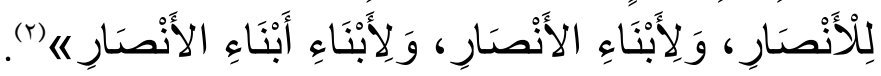

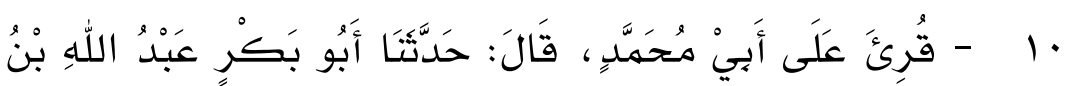

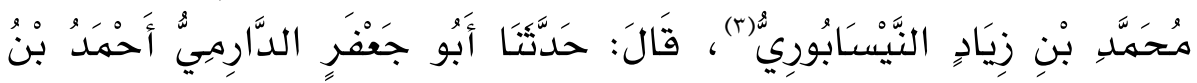

(1) النضر بن أنس بن مالك الأنصاري أبو ماللك البصري، ثقة، انظر : 》تهذيب التهذيبه

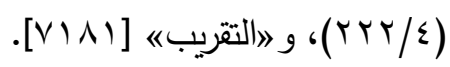

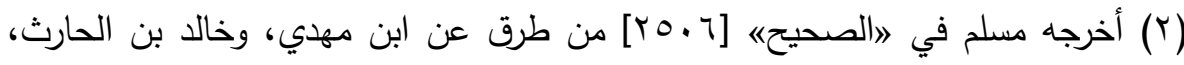

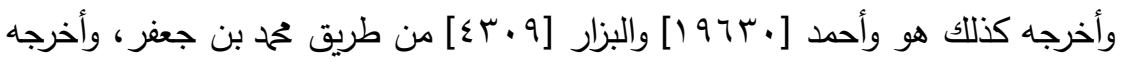

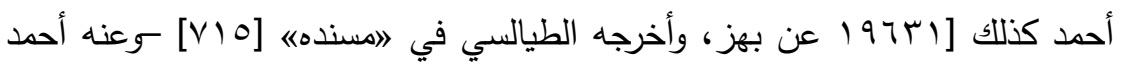

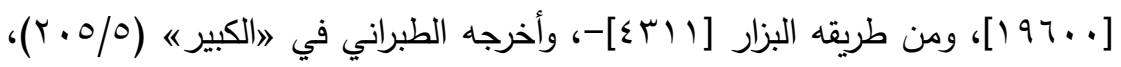

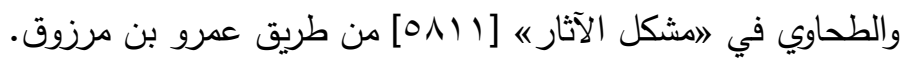
ستتهم، عن شعبة، به، كرواية النضر بن شميل.

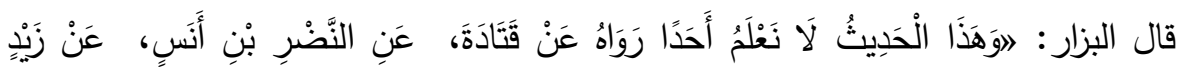

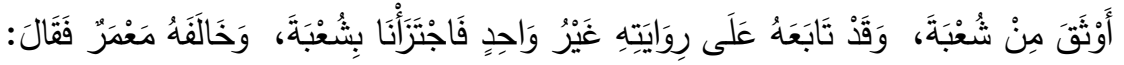

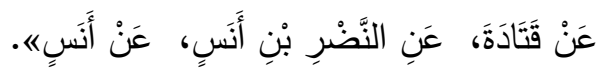
ولعل الدارقطني انتخبه لغرابته من حديث النضر بن بن شميل عن شعبة، والنضر من ثقات النّات المكثرين عن شعبة، و الله أعلم.

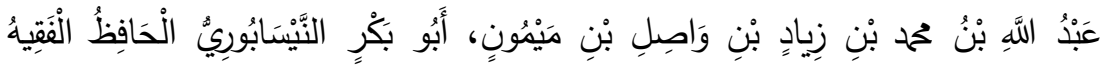

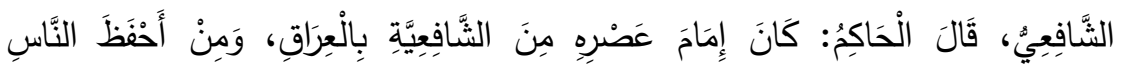

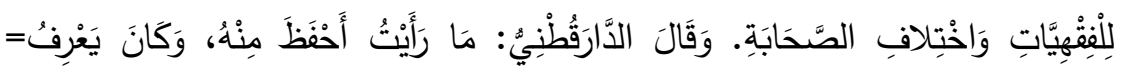

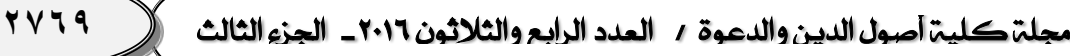

ت تــــــــون / فــاكسن 


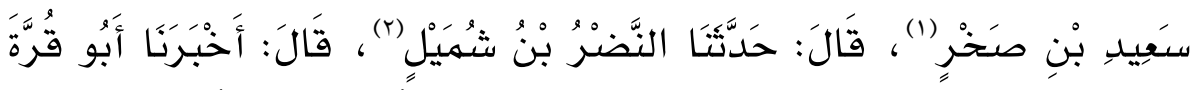

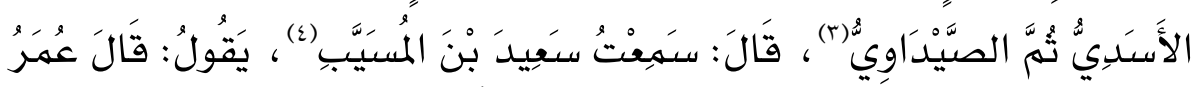

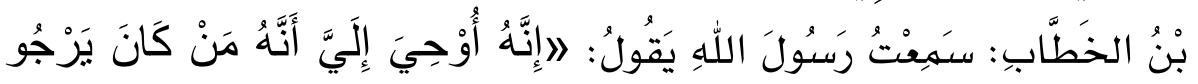

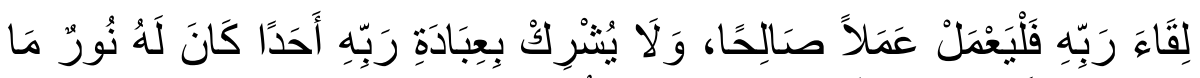

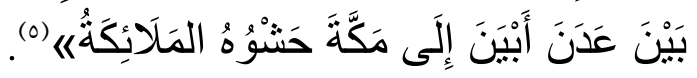

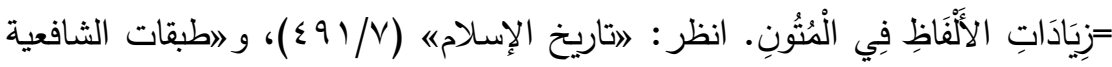

$$
\text { الكبرى《 (r/ • (1). }
$$

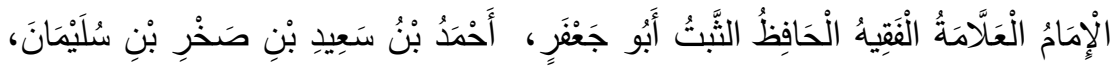

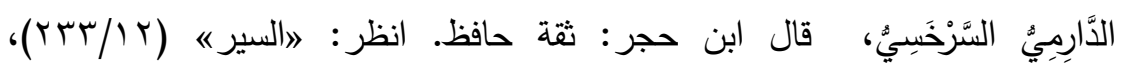

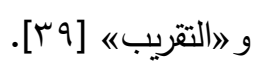

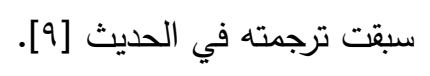

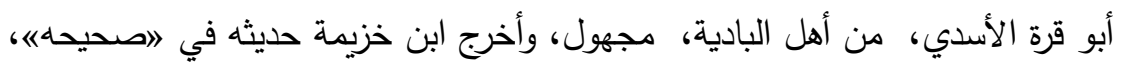

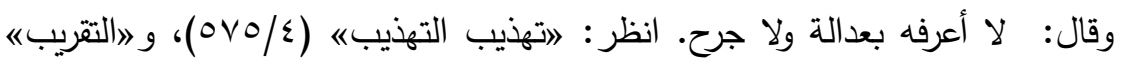

[^rหq]

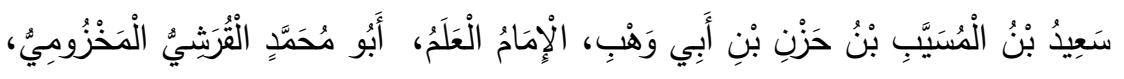

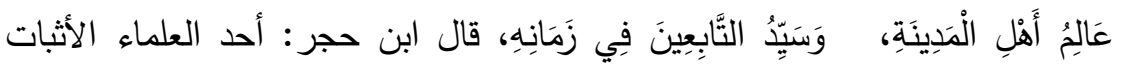

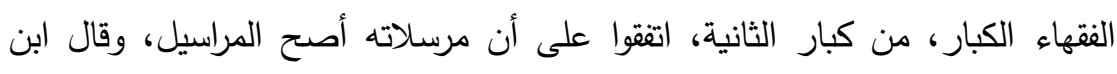

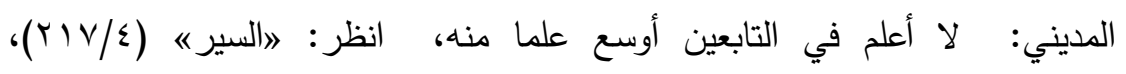

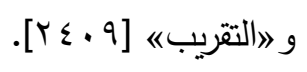

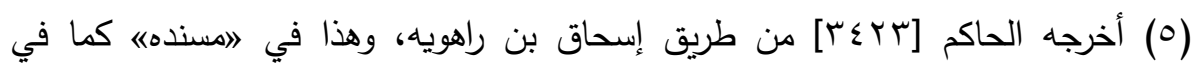

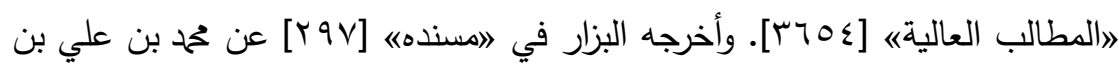
الحسن بن شقيق، كلاهما عن النضر بن شميل، به.

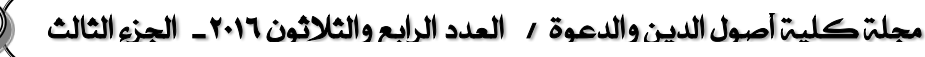


11

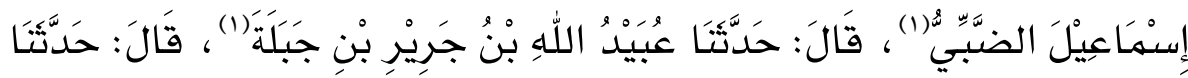

ووقع عند الحاكم كما عندنا (إنه قد أوحي إلي أنه من كان...) وهي قلقة، والذي في بقية

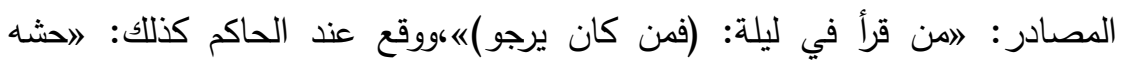

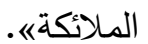

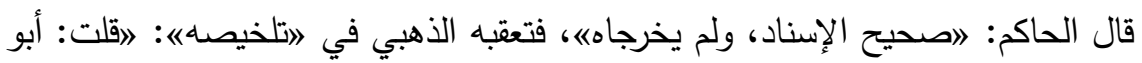

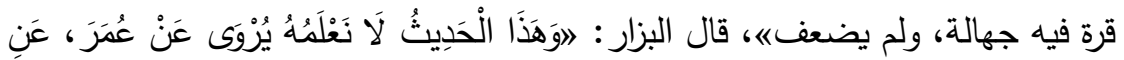

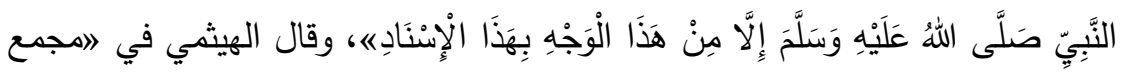

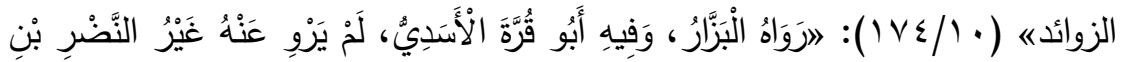

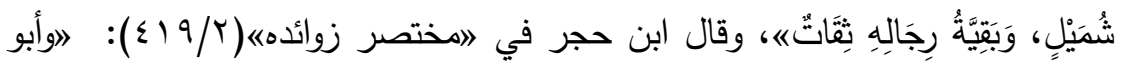

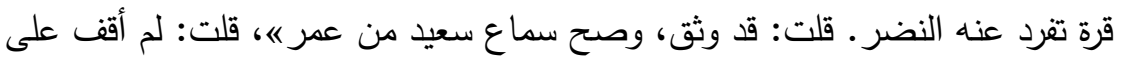

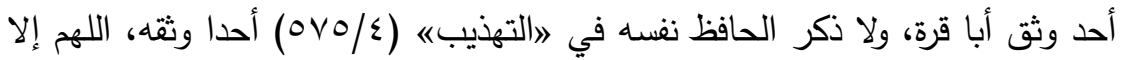

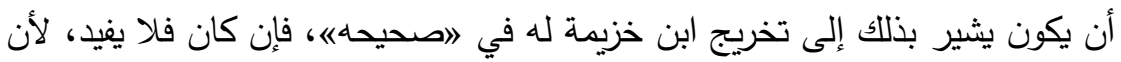

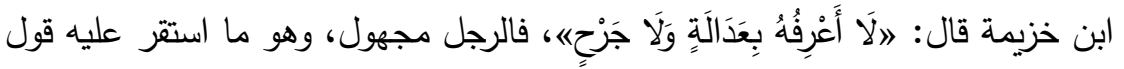

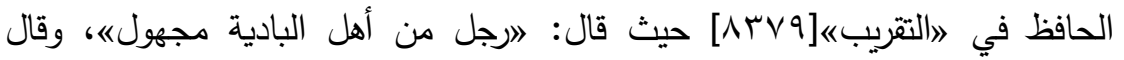

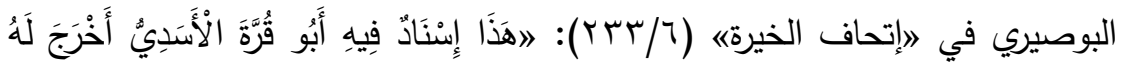

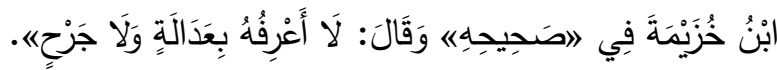

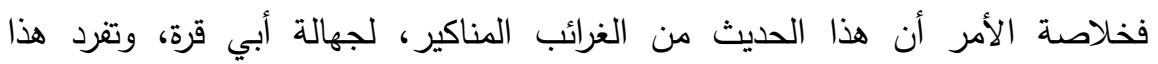
المجهول به عن مثل ابن المسيب، وعدم وجود ما يشهد له، و الله أعلم.

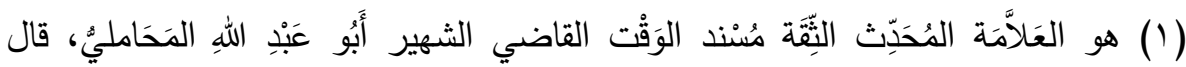

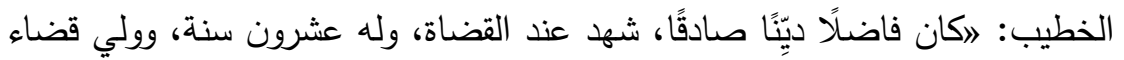

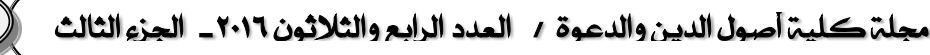




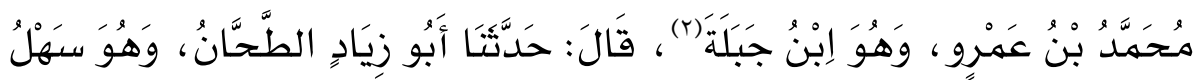

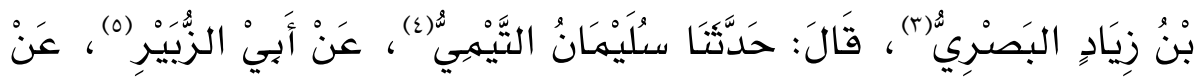

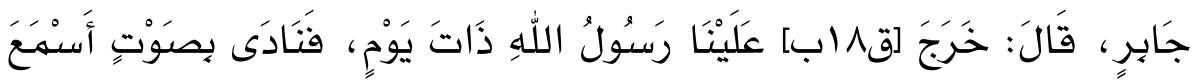

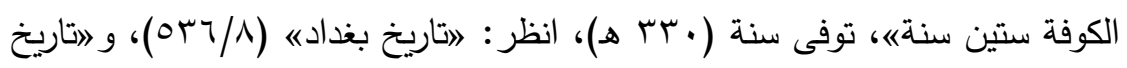

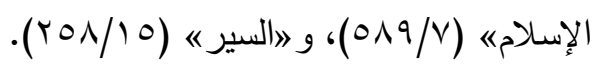

هو عبيد الله بن جرير بن جبلة بن أبي رواد أبو العباس، وقيل: أبو الحسن العتكي

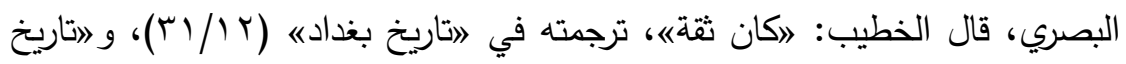

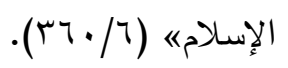

هو حمح بن عمرو بن عباد بن جبلة بن أبي داود العتكي مولاهم أبو جعفر البصري،

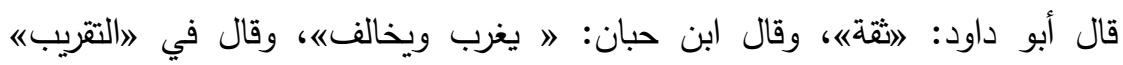

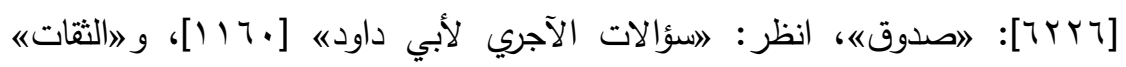

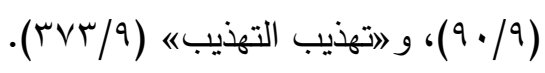

قال فيه الإمام أحمد: 》لا أعلم إلا خيراه، وقال البزار: لاليس به بأس《، وفي لامسند أبي يعلى" [V · VV]: اثنا إسحاق بن أبي إسرائيل، ثنا سهل بن زياد الحربي بصري

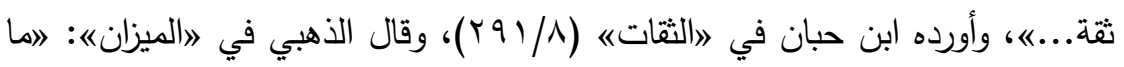
ضعفوه، صدوق إن شاء اللهی، وقد نقل ابن حجر في 》اللسانه [99 جب] قول الأزدي فيه: 》منكر الحديث《، وهو مع كونه غير مفسر ، فالأزدي متعنت وقد خالف جمهور

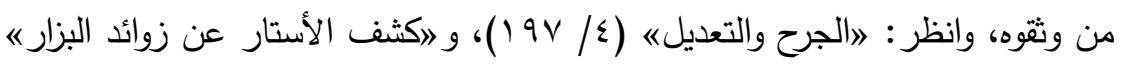

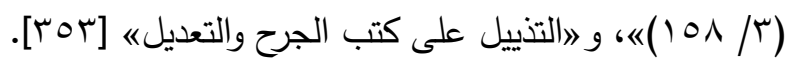

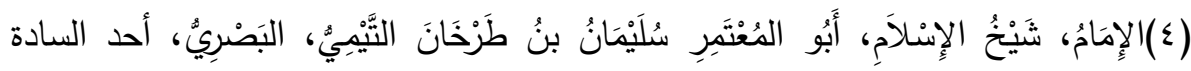

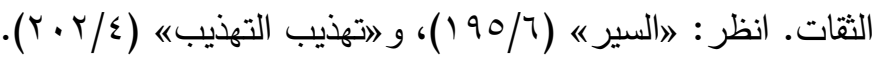

$$
\begin{aligned}
& \text { سبقت ترجمته في الحديث [ᄉ]. }
\end{aligned}
$$




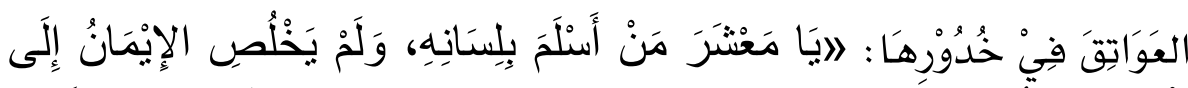

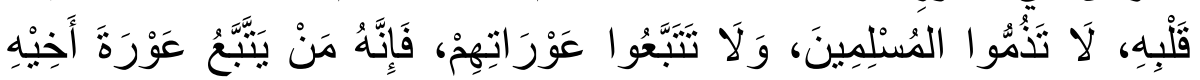

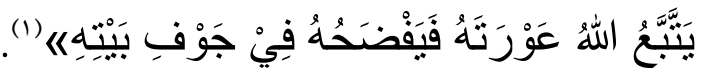

ا

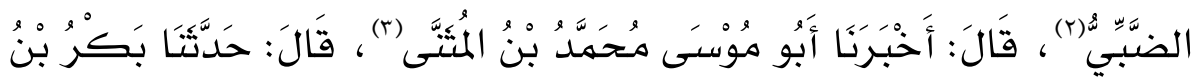

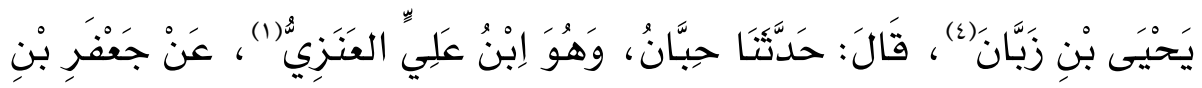

(1) أخرجه ابن المستوفي في 》تاريخ إربله (1/ (9) من طريق المصنف بتمامه، وهو غريب من هذا الوجه، ولعله من غرائب محمد عمرو بن جبلة، فقد قال ابن حبان فيه: "ايغرب ويخالفه، فالله أعلم.

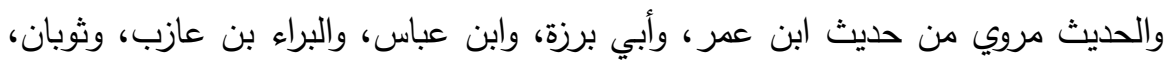

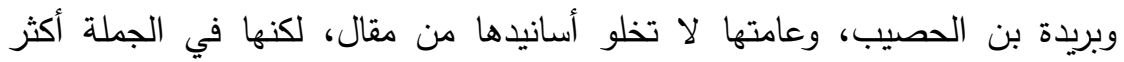

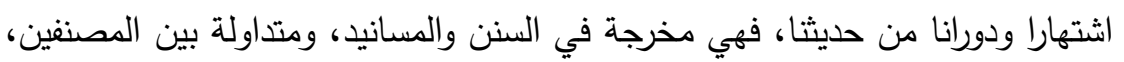
ولست أرى حاجة لتخريجها هنا، و الله أعلم.

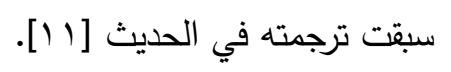

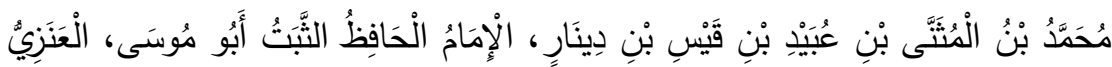

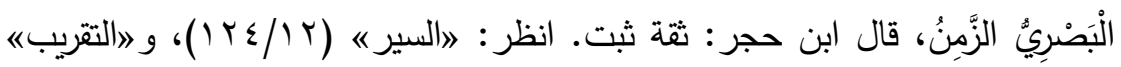

$$
\text { [־. }
$$

بكر بن يحيى بن زبان بزاي مفتوحة وموحدة ثقيلة، عبدي، ويقال: عنزي بنون وزاي،

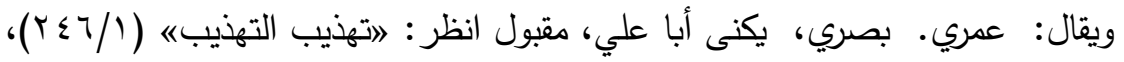

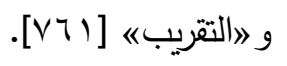




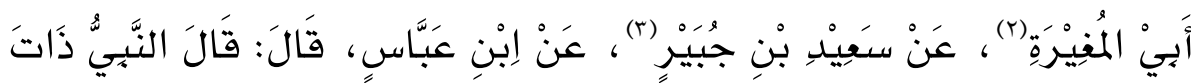

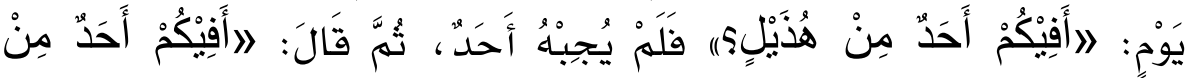

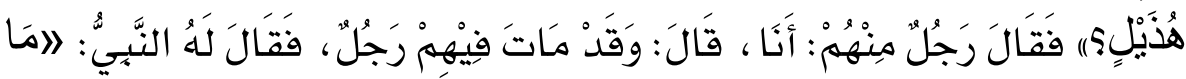

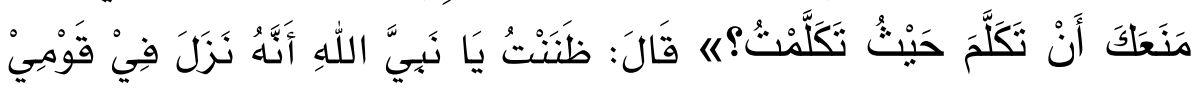

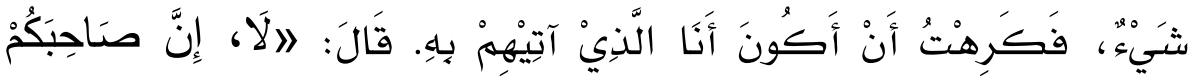

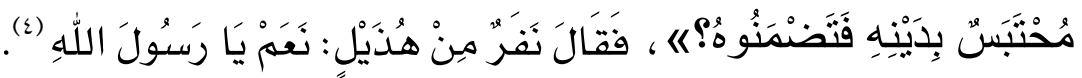

حبان بن علي العنزي بفتح العين والنون ثم زاي، أبو علي، الكوفي، ضعيف، وكان

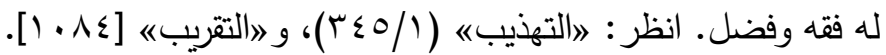

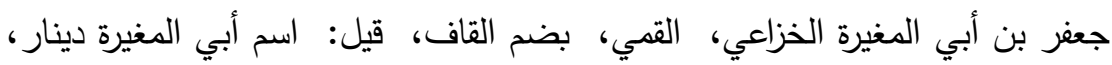

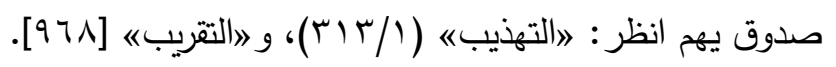

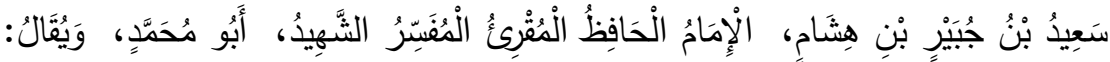

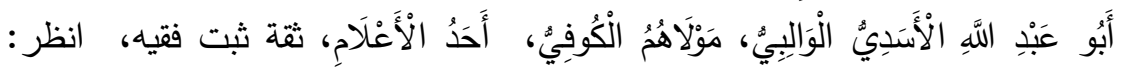

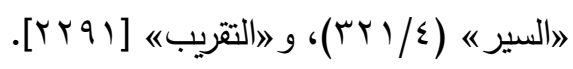

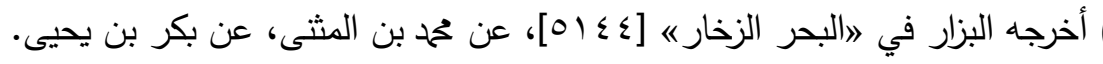

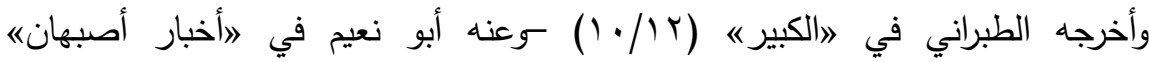

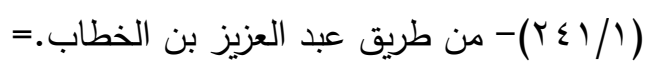

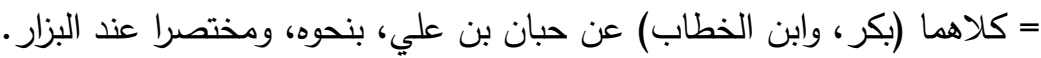

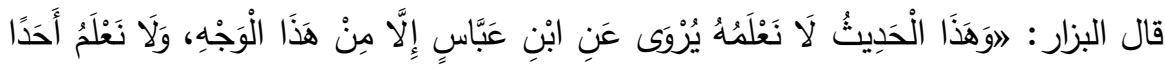

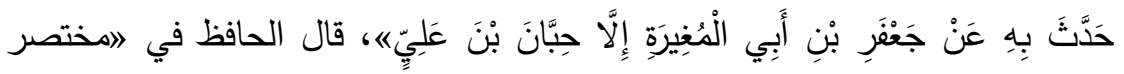

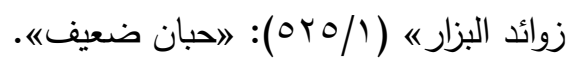




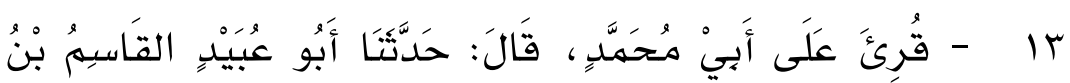

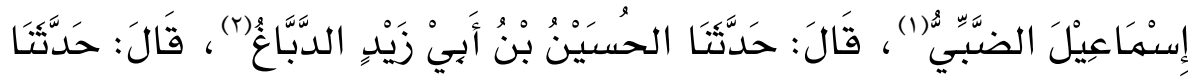

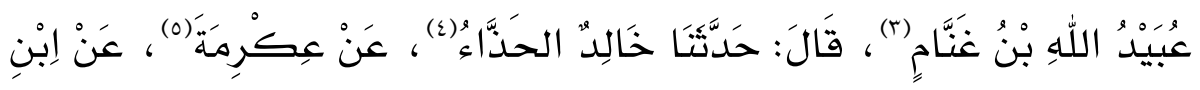

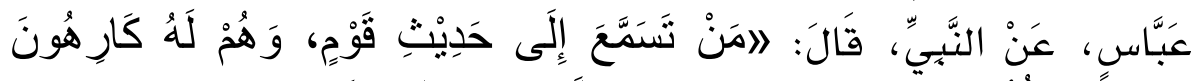

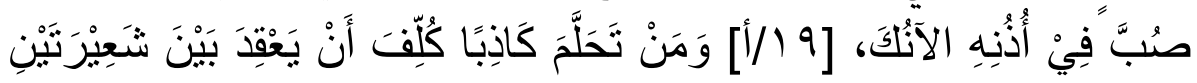

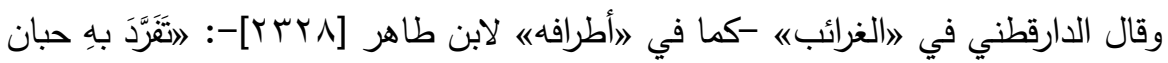
بن علي عن جعفر بن أبي المغيرة، عَنها.

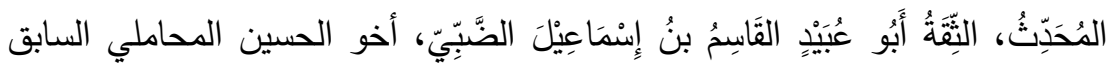

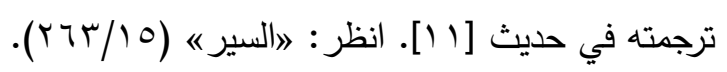

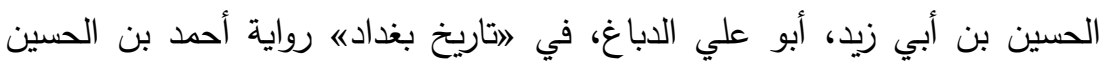

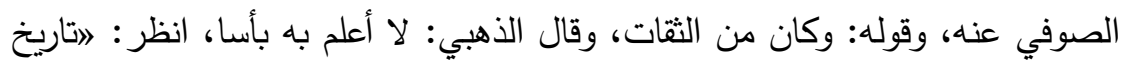

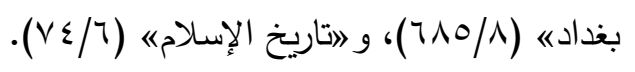

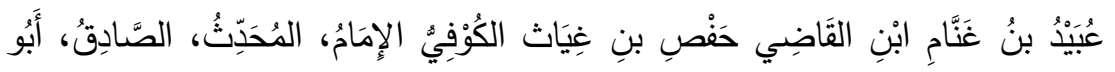

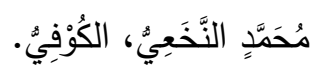

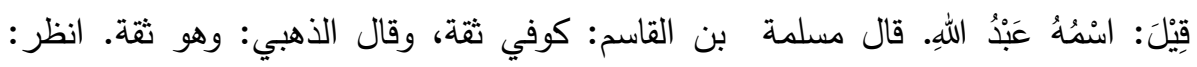

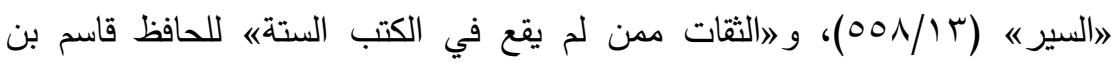

$$
\begin{aligned}
& \text { قطلوبغا [VOrr] } \\
& \text { سبقت ترجمته في الحديث [V]. }
\end{aligned}
$$

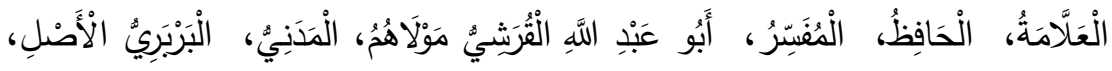

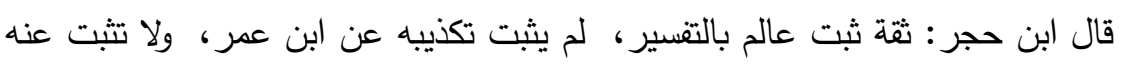

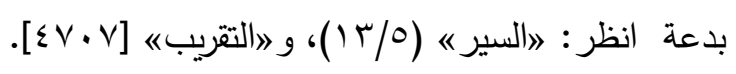

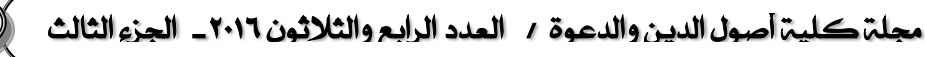




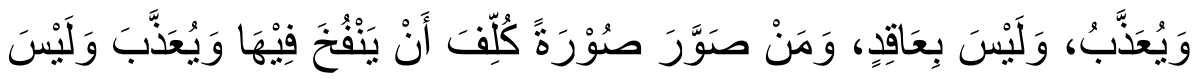

بَنَافِخِ

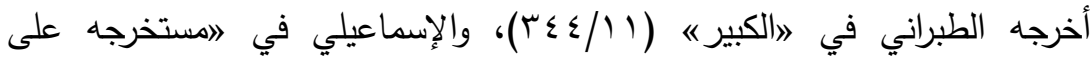

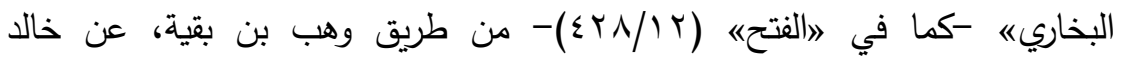

الطحان، عن خالد الحذاء، به مرفوعا.

وأخرجه الإسماعيلي كذللك من طريق وهيب بن خالد، وعبد الوهاب الثقفي، عن خالد الحذاء، به مرفوعا كذللك.

ولعل الدارقطني قصد أنه من هذا الوجه عن الحذاء عن عكرمة عن ابن عباس مرفوعا

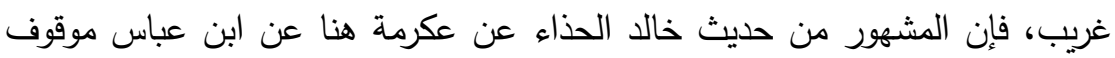

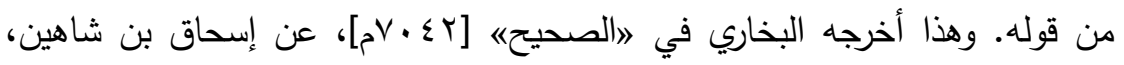

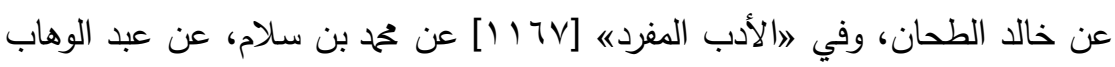
التثقي، كلاهما عن خالد الحذاء، به موقوفا على ابن عباس. قال البخاري بعد أن ساقه: اوقد تابعه هشام عن عكرمة عن ابن عباس قَوَْلَهُه.

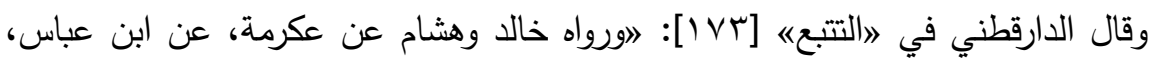
موقوفاً، واختلف عنهماه.

= والحديث محفوظ كذلك عن عكرمة، عن ابن عباس لكن من غير طريق الحذاء، فقد رواه

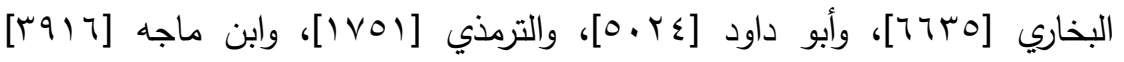
وغيرهم من طرق عن أيوب السختياني، عن عكرمة، عن ابن عباس رضي الله عنهما

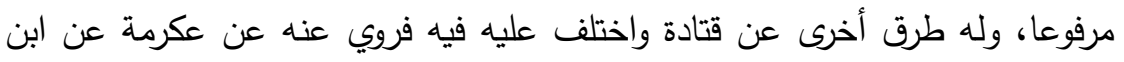

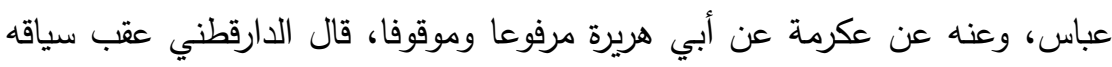

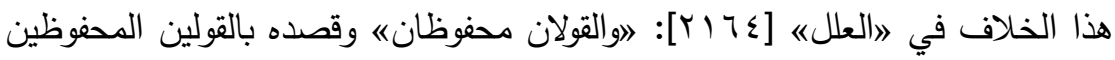
أنه محفوظ من حديث أبي هريرة وابن عباس، و الله أعلم.

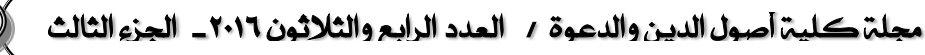




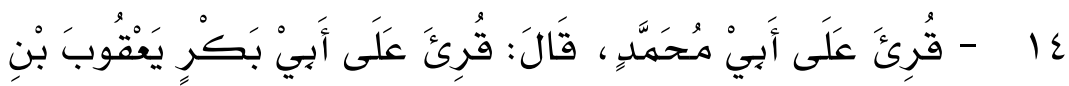

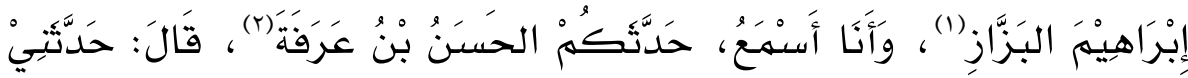

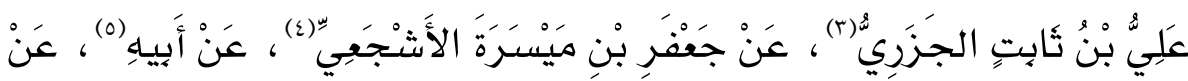

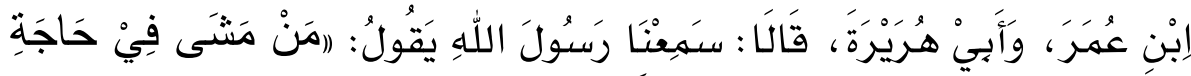

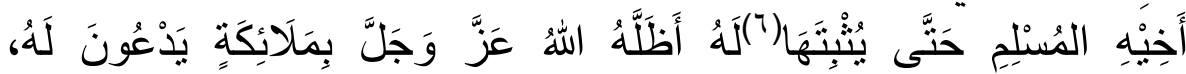

يعقوب بن إبراهيم بن أحمد بن عيسى بن البَختري أبو بكر البزاز يعرف بالجَرَاب، قال

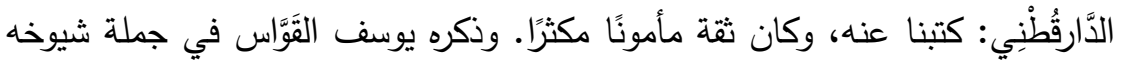

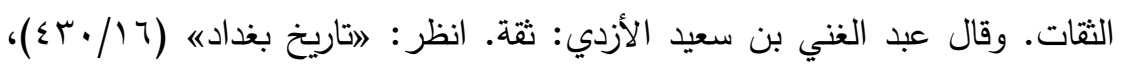

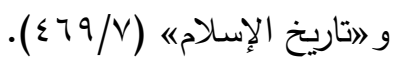

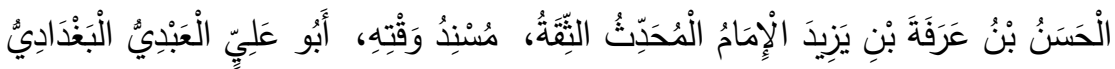

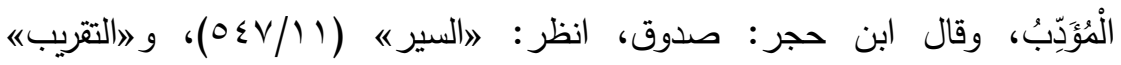
[1 [1 Tro]

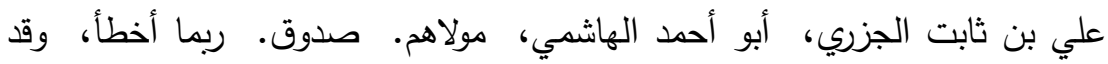

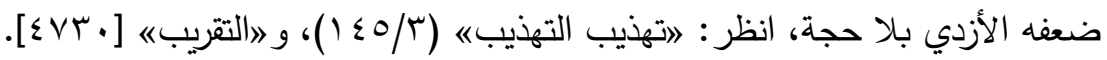

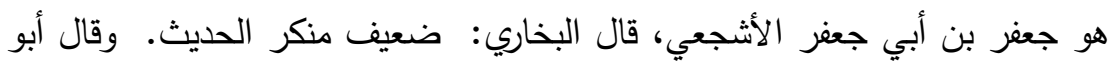

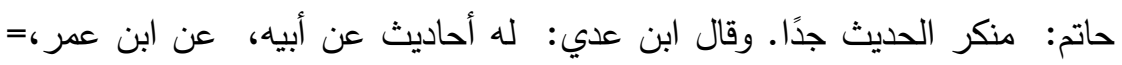

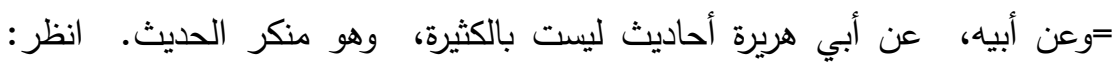

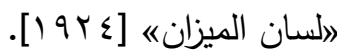
ميسرة مولى موسى بن باذان مديني، أبو جعفر الأشجعي، ذكره ابن أبي حاتم في

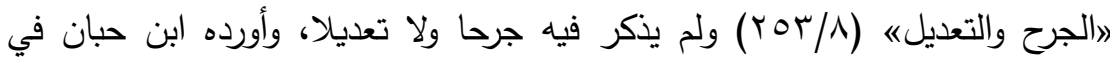

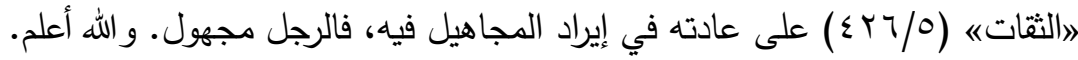

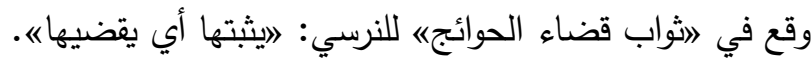

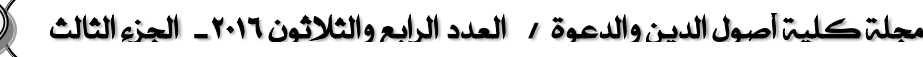




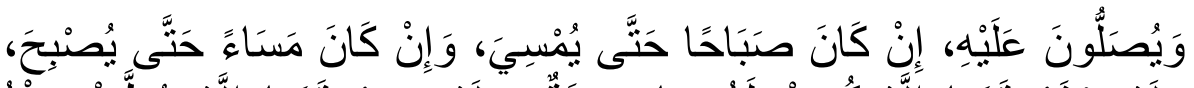

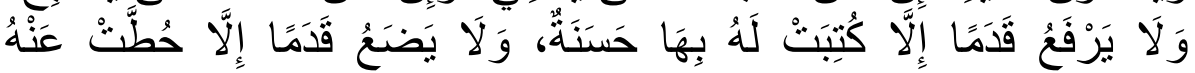

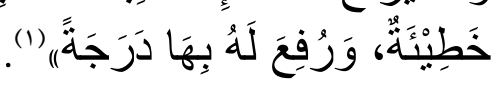

10

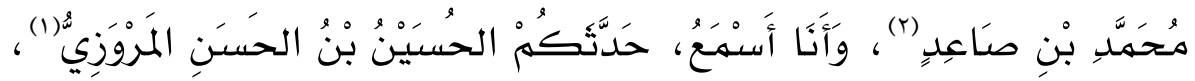

(1) أخرجه الخرائطي في 》ككارم الأخلاقه [19]، وابن شاهين في 》الترغيب في فضائل

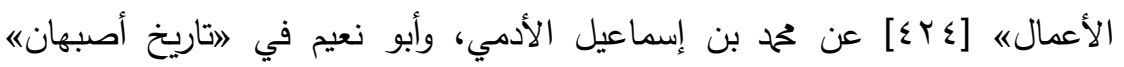

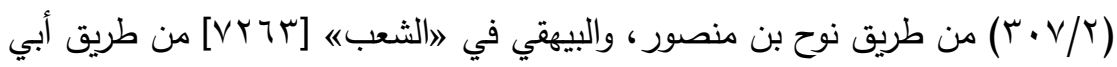

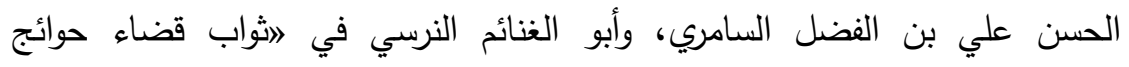

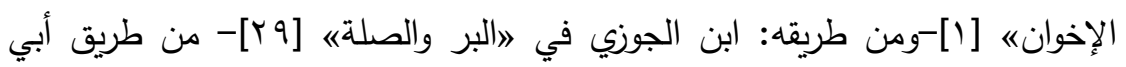

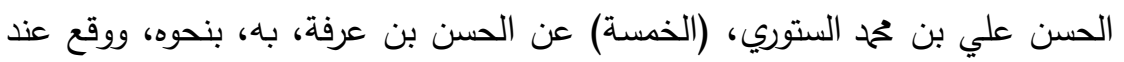

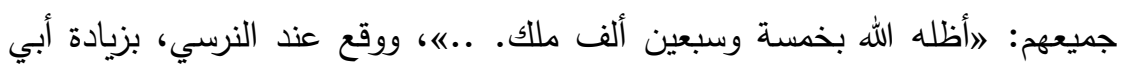

$$
\text { سعيد الخدري مع ابن عمر وأبي هريرة. = }
$$

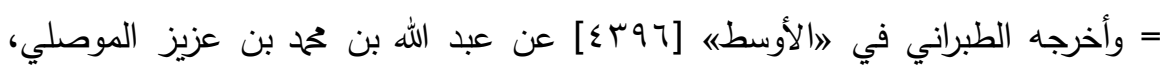

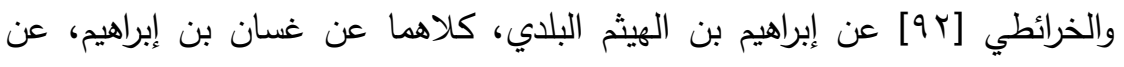
جعفر بن ميسرة، به، غير أنه في رواية الطبراني موقوف على إنى ابن عمر وأبي هريرة،

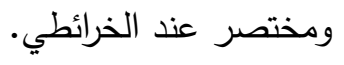

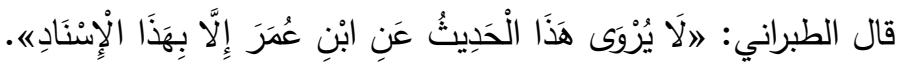

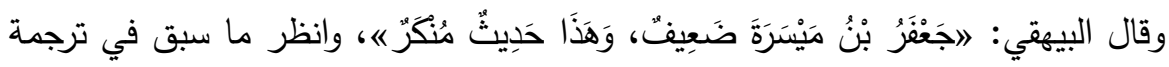
جعفر ، وأبوه ميسرة مجهول كذلك كما سبق.

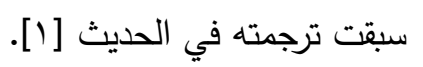




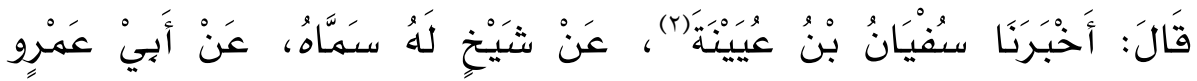

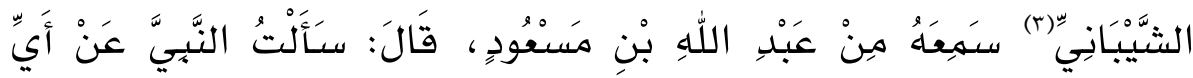

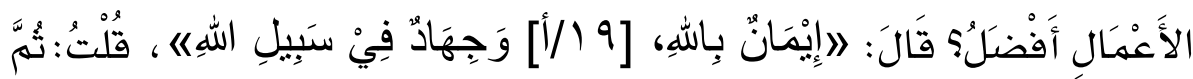

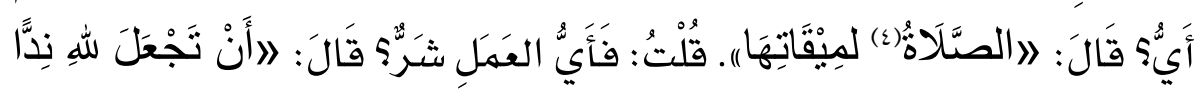

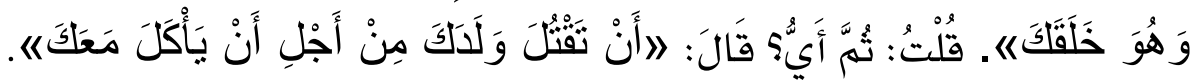

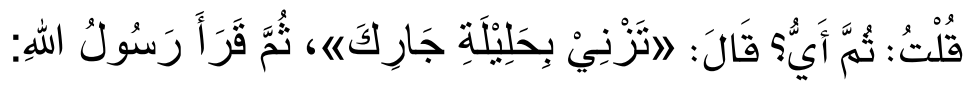

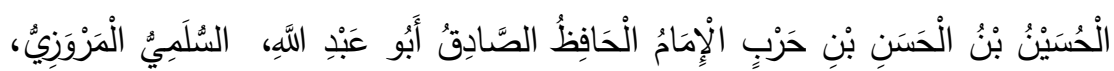

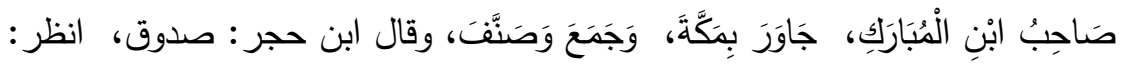

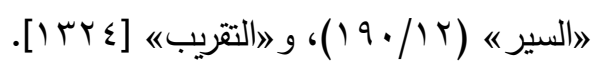

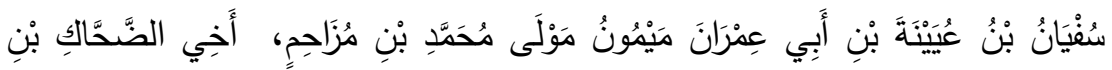

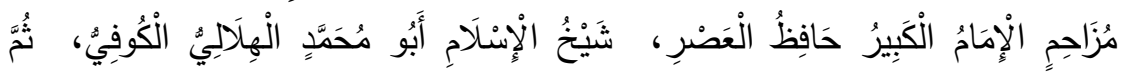

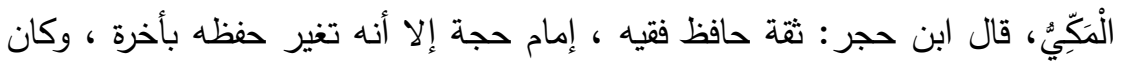

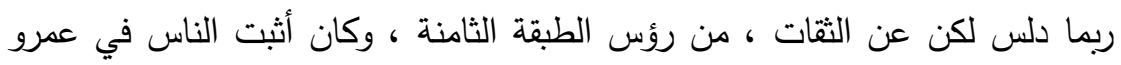

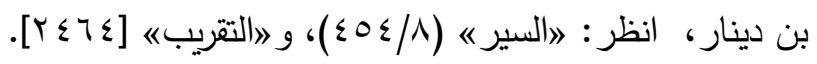

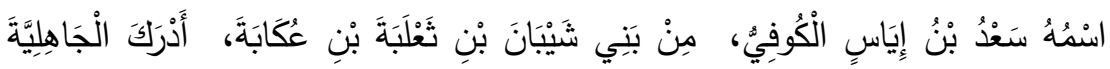

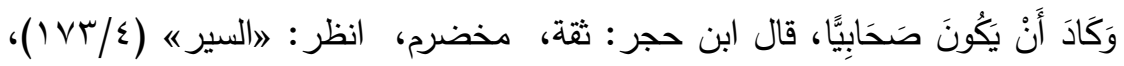

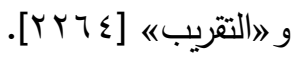
(ك) أقحم هنا في الأصل: اثم أي؟ قال: الصلاة أَفْضَلُ، قال: إيمان بالله وجهاد في سبيل اللهه ويظهر أنه انتقال نظر من الناسخ.

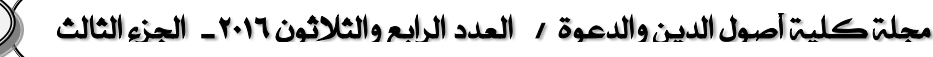


我

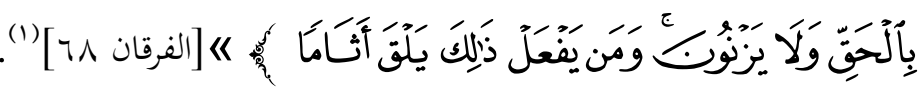

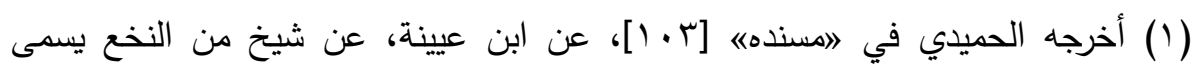

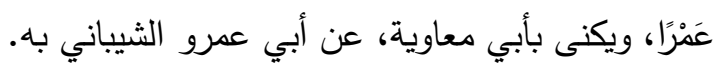

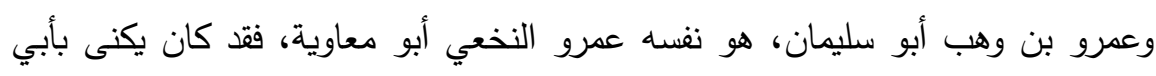

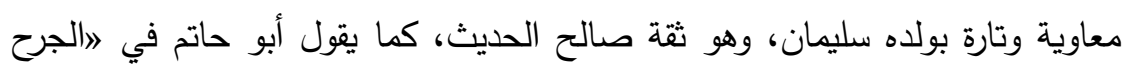

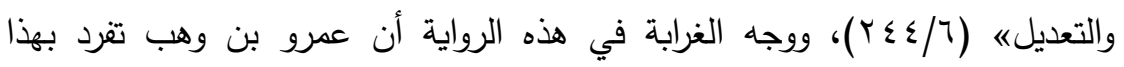

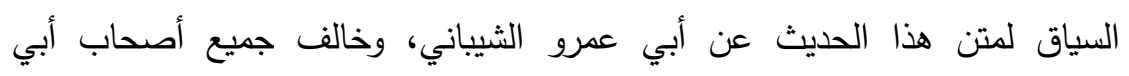
عمرو. $=$

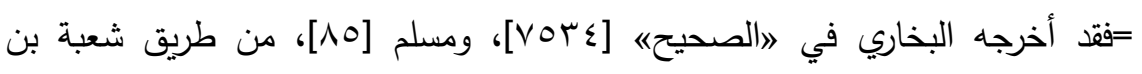

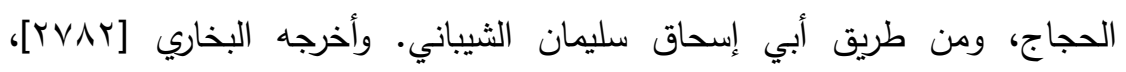

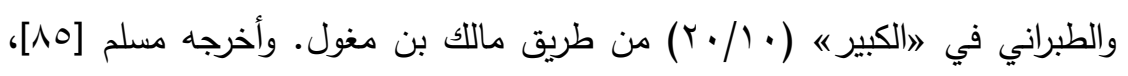

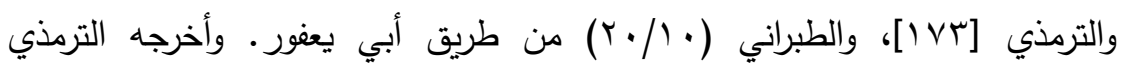

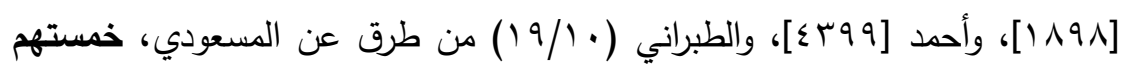

$$
\text { عن الوليد بن العيزار. }
$$

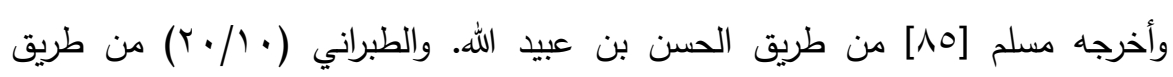

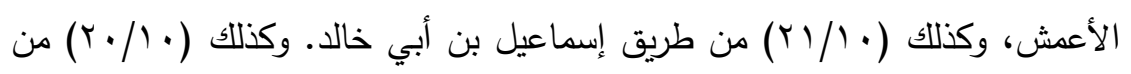

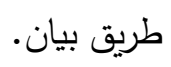

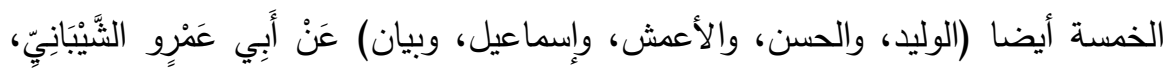

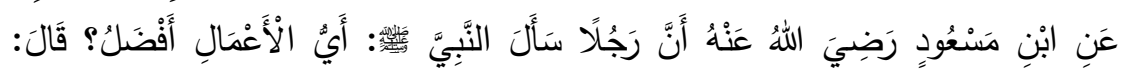

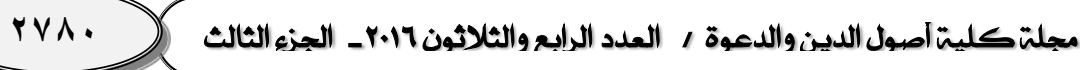

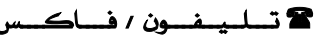




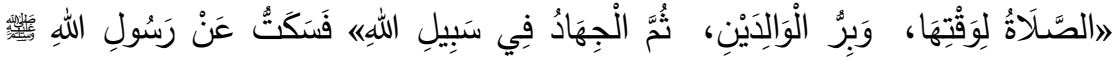

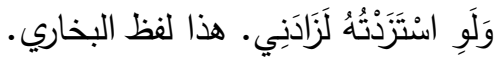

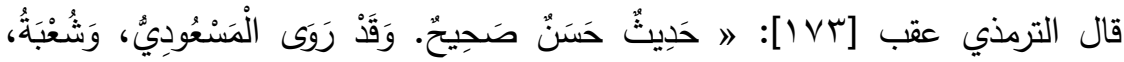

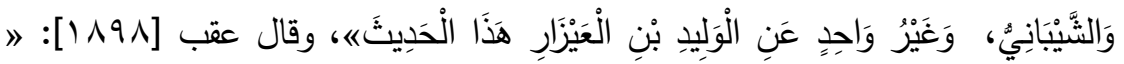

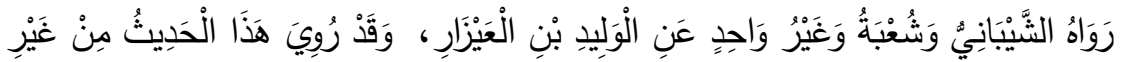

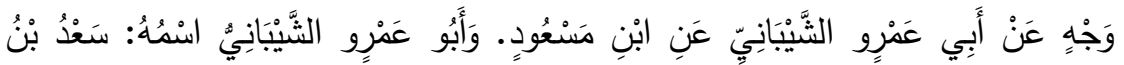
إِيَاس وقال الدارقطني في 》العلله (ب/0/\%) بعد أن ساق بعض الخلاف الذي فيه: 》 وهو صحيح عن أبي عمرو الثيباني عن ابن مسعوده.

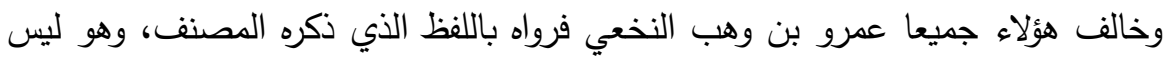
لفظ أبي عمرو الذي رواه عنه جميع أصحابه، كما سبق، وإنما يروى بهذا اللفظ من

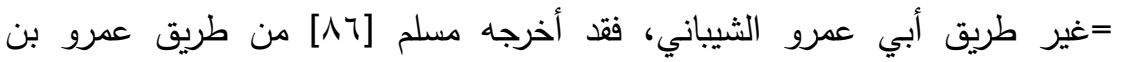
شرحبيل، عن ابن مسعود.

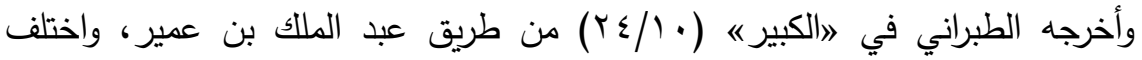
عليه، فرواه عنه حماد بن سلمة هنا عن ابن مسعود، وهذا منقطع فإن عبد الملك لم الم يدرك ابن مسعود، ورواه عنه أبو شيبة يزيد بن معاوية، عن زر بن حبيش عن عن ابن وناه

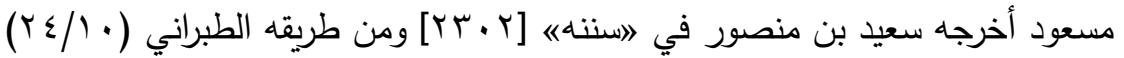
باللفظ الذي ذكره المصنف هنا عن أبي عمرو الثيباني. نعم تابع عمرو بن وهب على هذا اللفظ عن الثيباني أبو إسحاق السبيعي، فأخرجه

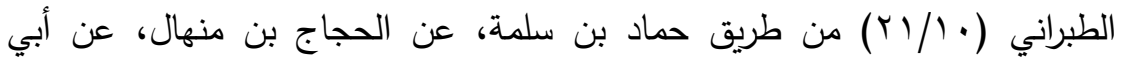

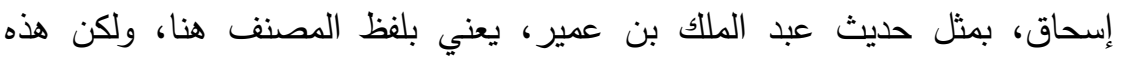

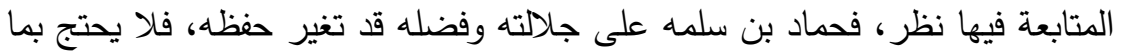




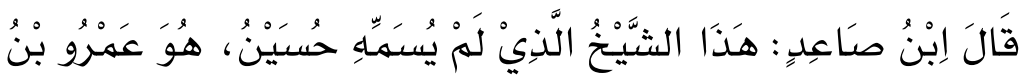

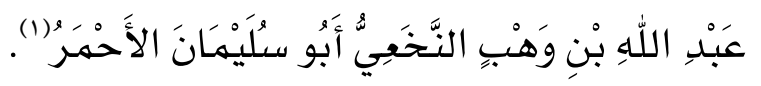

17

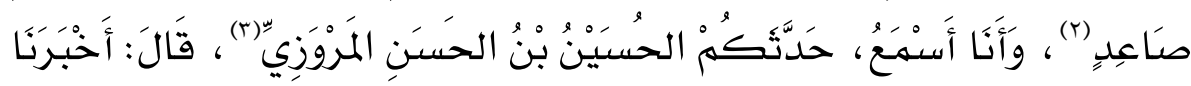

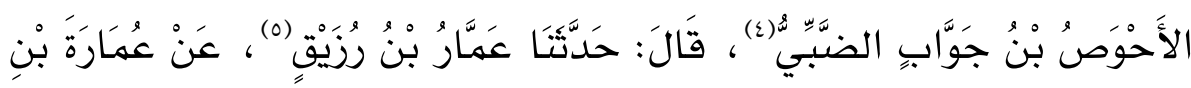

يخالف فيه الثقات كما هنا، وأبو إسحاق هو السبيعي الإمام لكنه مدلس ولم يصرح بالتحديث هنا، ثم قد خالف ابن سلمة حماد بن زيد كما سبق عند الطبراني فرواه عن حجاج، عن الأعمش، عن أبي عمرو الثيباني بلفظ الجماعة من أصحاب الشيباني، وحماد بن زيد أثبت وأتقن من ابن سلمة، رحم الله الجميع، و الله أعلم. فيكون هذا موضع الغرابة فيما انتخبه الدارقطني هنا و الله أعلم. عمرو بن عبد الله بن وهب النخعي أبو معاوية الكوفي، ثقة، انظر: 》التهذيب؛

$$
\begin{aligned}
& \text { (Y) } \\
& \text { سبقت ترجمته في الحديث [1]] }
\end{aligned}
$$

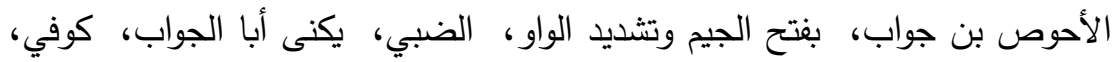

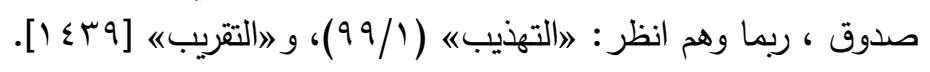

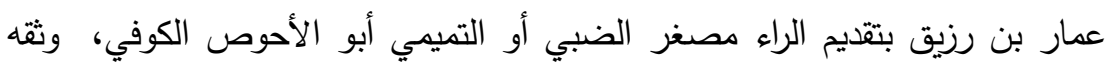

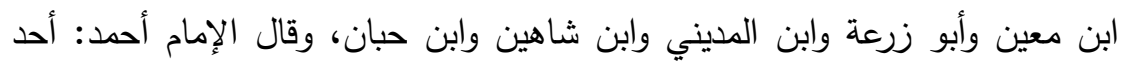

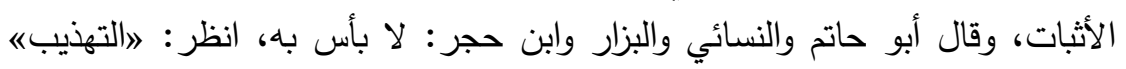

$$
\text { (Y) }
$$




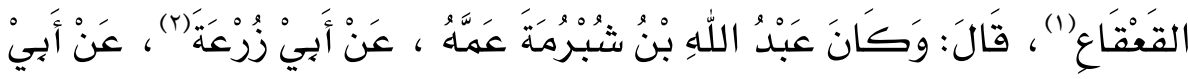

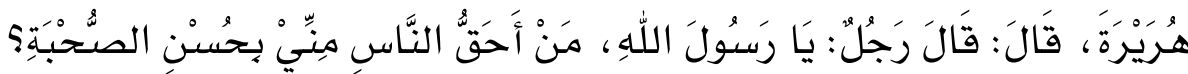

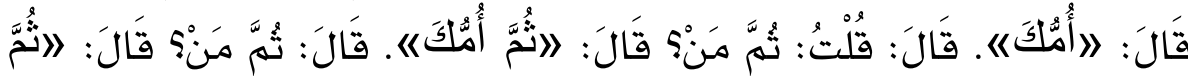

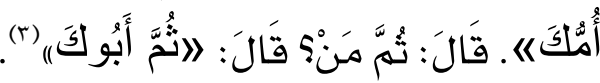

عمارة بن القعقاع بن شبرمة بضم المعجمة والراء بينهما موحدة ساكنة الضبي

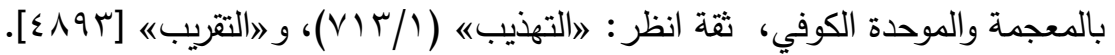

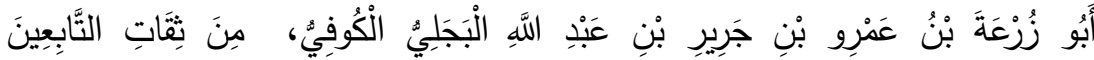

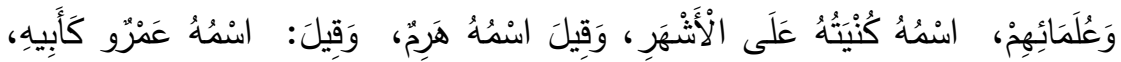

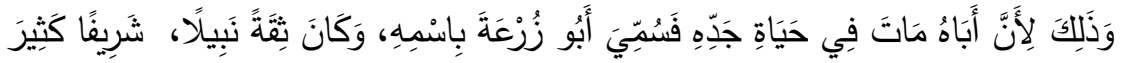

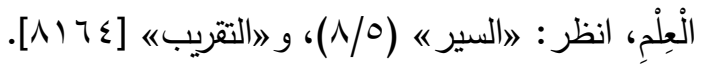

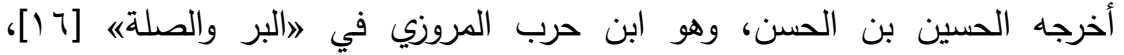

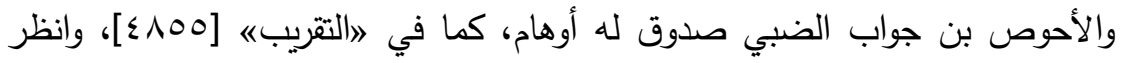

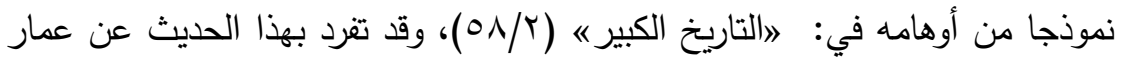
بن رزيق، عن عمارة بن القعقاع، ولعله لذلك انتخبه الدارقطني هنا في الغرائب وقائب. $=$

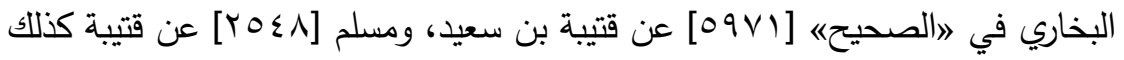

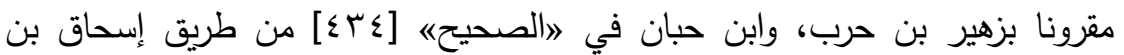

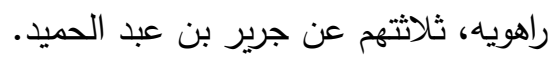

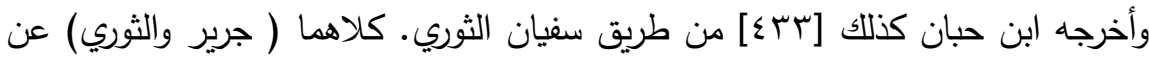
عمارة بن القعقاع، به.

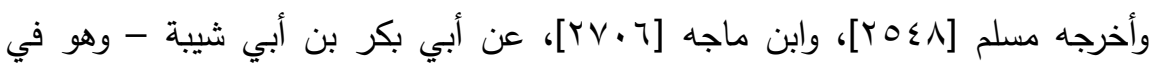

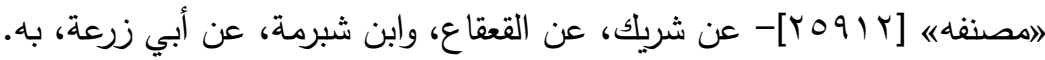

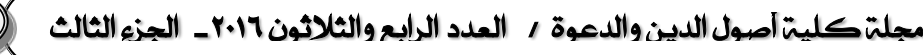


IV

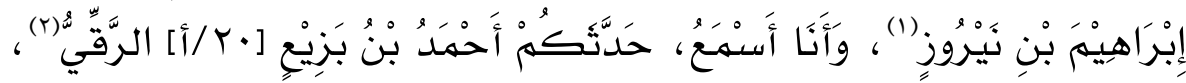

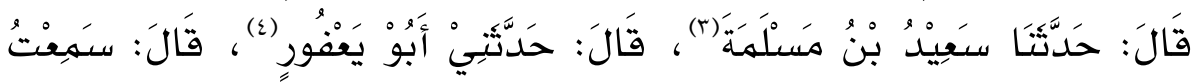

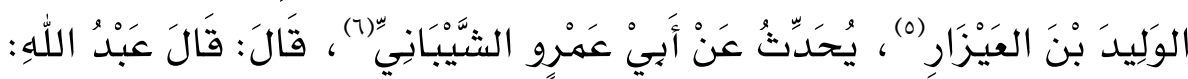

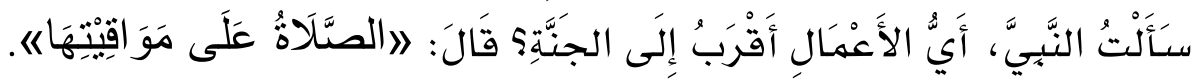

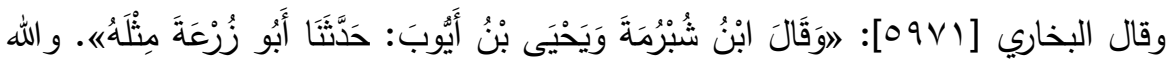

$$
\text { سبقت ترجمته في الحديث [7]. }
$$

(Y) هو أبو علي الخفاف الرقي، من شيوخ ابن صاعد، كما في 》المقتنى في سرد الكنى"

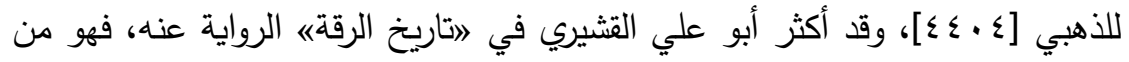

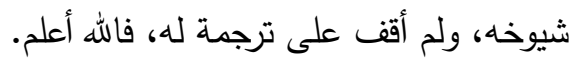

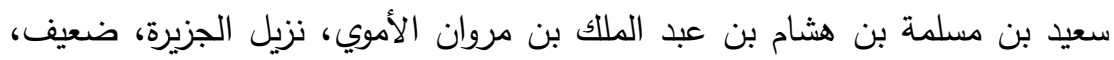

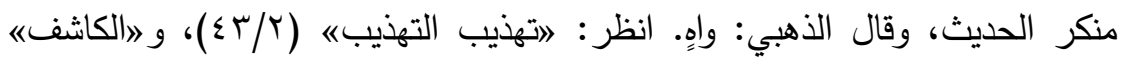

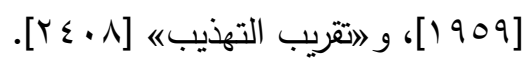

(ء) هو عبد الرحمن بن عبيد بن نِسْطَسٍ، بكسر النون وسكون السين المهملة، مختلف في

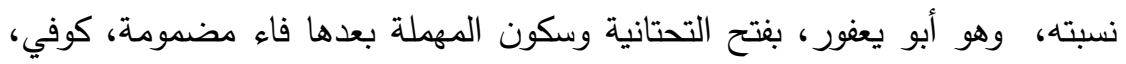

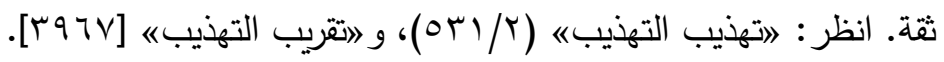

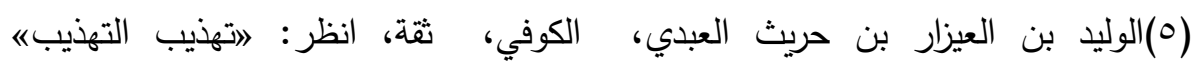

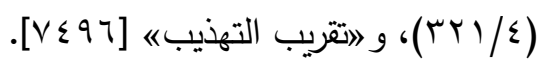

$$
\begin{aligned}
& \text { سبقت ترجمته في الحديث [10]. }
\end{aligned}
$$

YVA

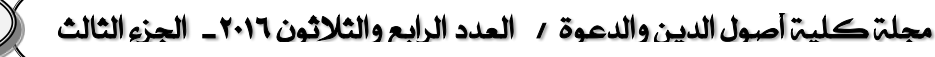




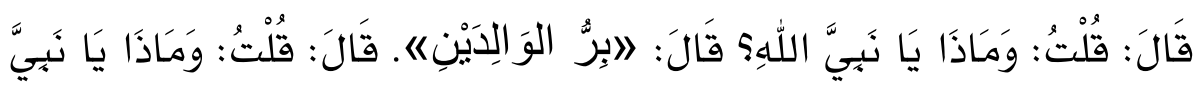

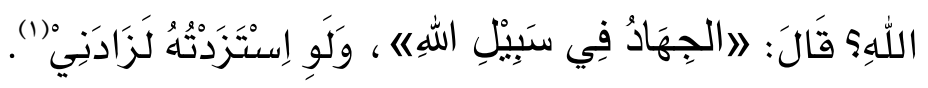

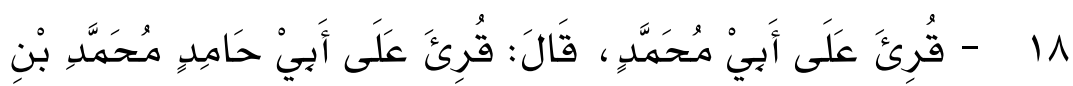

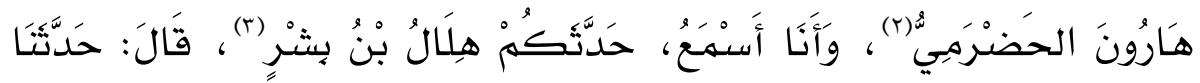

لم أقف عليه بهذا الإسناد في غير هذا الموضح، وسعيد بن مسلمة ضعيف، منكر

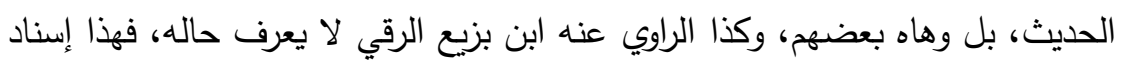

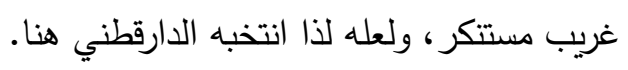

وإلا فالحديث ثابت عن أبي يعفور من غير هذه الطريق، ومخرج في لاصحيح مسلمه، وقد سبق تخريجه في الحديث [0 10]، فراجعه إذا شئت.

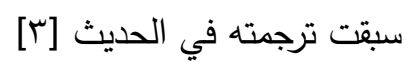

(r) هو هلال بن بشر بن محبوب المزني، أبو الحسن البصري الأحدب، إمام مسجد يونس

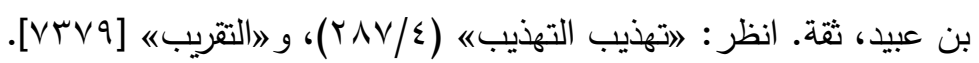




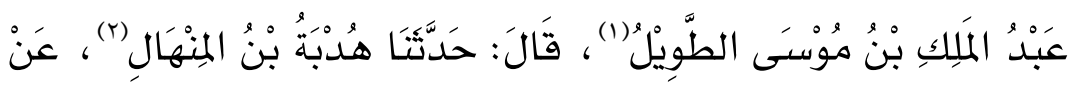

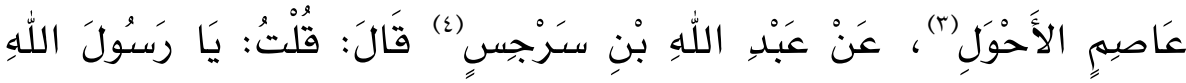

هو أبو بشر عبد الملك بن موسى الطويل، عن أبي هاشم صاحب الرمان، روى عنه

هلال بن بشر ، كذا ساق ترجمته الإمام مسلم في 》الكنى والأسماء《 [^ . ع]، ولم يذكر فيه غير ذلك، وفي 》الميزانه [7هro]: 》عن أنس، لا يدري من هو؛ وقال الأزدي:

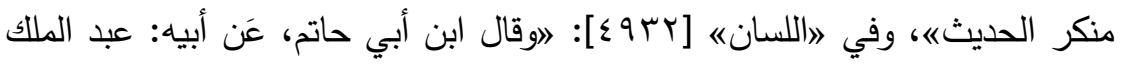
الطويل سمع عائشة سمع منه عتاب بن الحكم مجهول، وذَكَره ابن حِبَّن في 》الثقات《. فيحتمل أن يكون هو ابن موسى ويحتمل أن يكون آخرش، قلت: ولو كان عبد الملك الطويل هو ابن موسى المترجم في 》الميزانه فهل هو المترجم في 》الكنى" لمسلم أو غيره؟ فإن الذي في 》الميزانه أعلى طبقة من الذي في 》الكنى《، وعلى كل فالرجل على أي تقدير مجهول لا يعرف، وتوثيق ابن حبان لو صح أنه فيه فلا يفيده شيئا، فإنها يوثق المجاهيل، فكان ماذا؟. هو هدبة بن المنهال الأسدي، كذا في 》الجرح والتعديله (9/ع 1 ())، و 》التاريخ

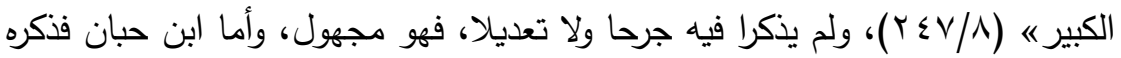
في 》الثقاته ( الأهواز - مان

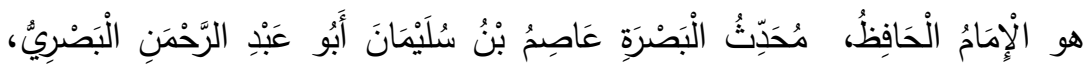

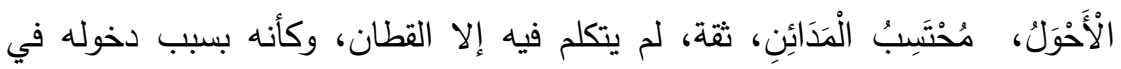

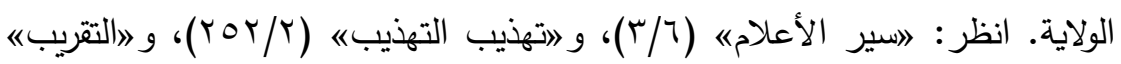
$\cdot[r \cdot V \vee]$

هو المزني، حليف بني مخزوم، ثابت الصحبة، وإنما ترجمته هنا لما في 》الإصابة)

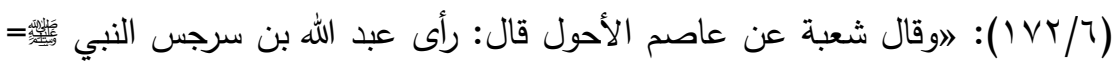




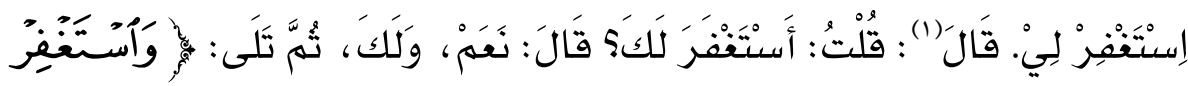

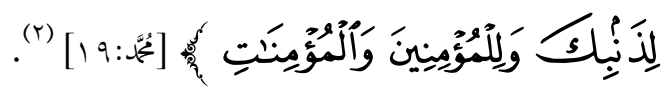

$=$

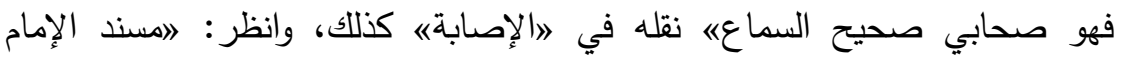

$$
\text { أحمد《 [T - 11) }
$$

(1) القائل هو عاصم يخاطب ابن سرجس.

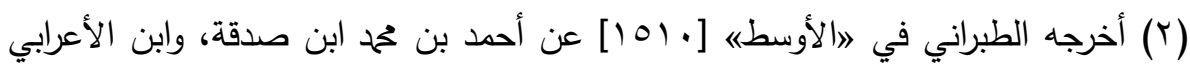
في 》معجمه" [IVTV

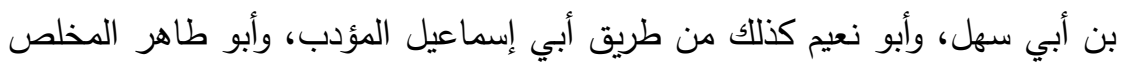

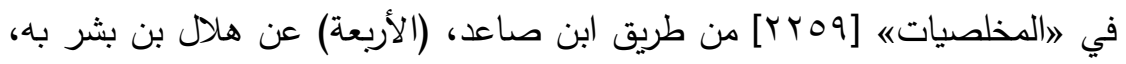

$$
\text { سواء. }
$$

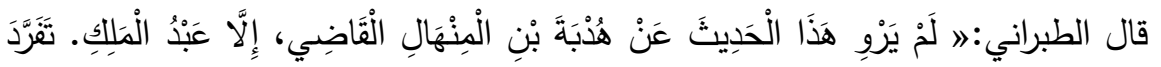

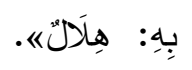

وهذا إسناد ضعيف بمرة، فعبد الملك بن موسى، وشيخه هدبة مجهولان لا يعرفان، وقد

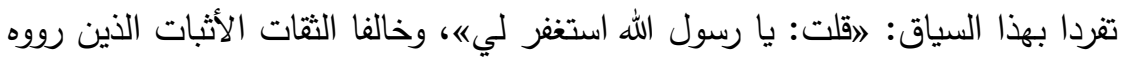

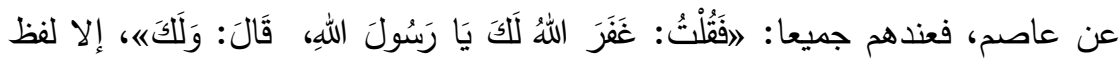
البكراوي عن عبد الواحد بن زياد عند مسلم فليس فيه هذه العبارة برمتها، وإنما فيه

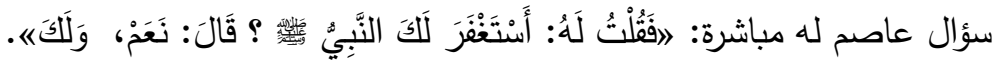

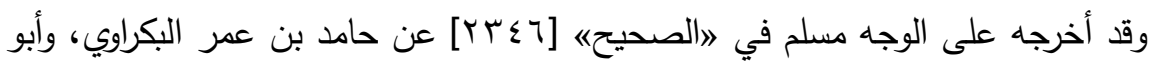

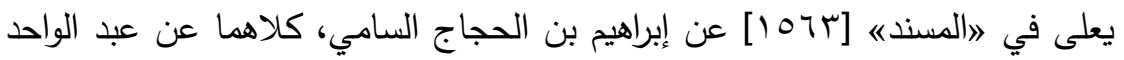
بن زياد.

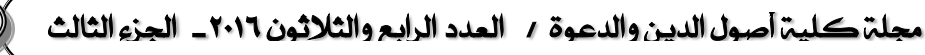


19

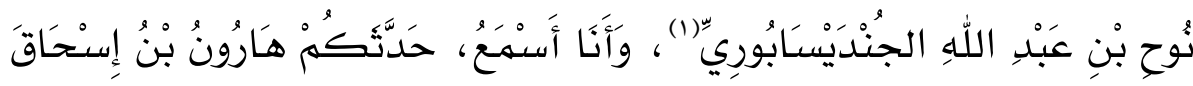

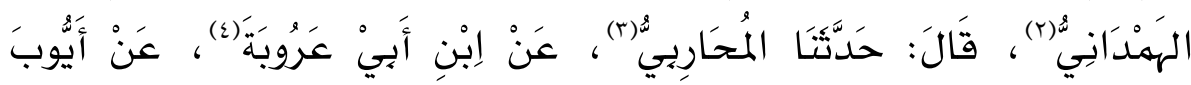

$=$

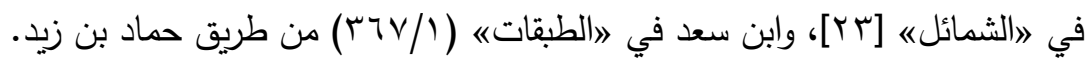

$$
\text { وأخرجه مسلم كذلك، من طريق علي بن مسهر . }
$$

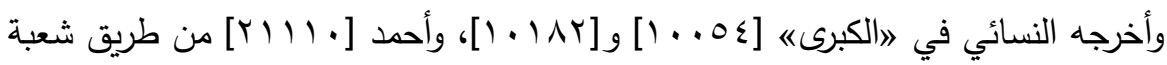

$$
\text { بن الحجاج. }
$$

الأربعة عن عاصم الأحول، عن عبد الله بن سرجس، به، و الله أعلم.

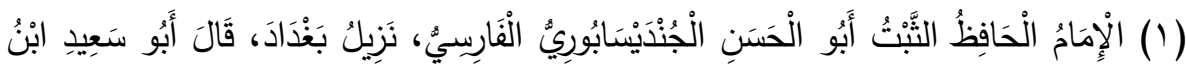

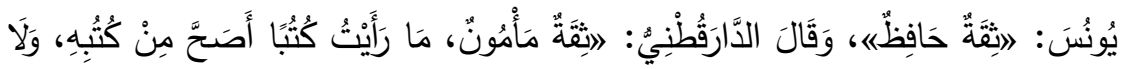

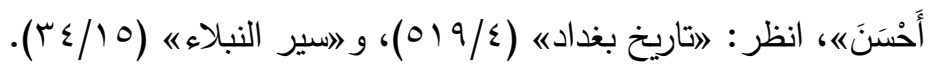

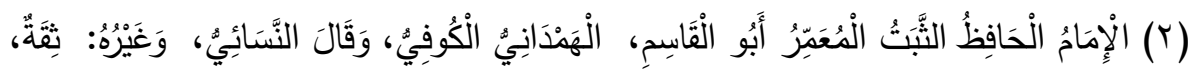

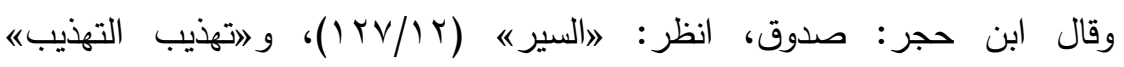

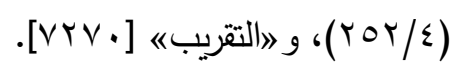

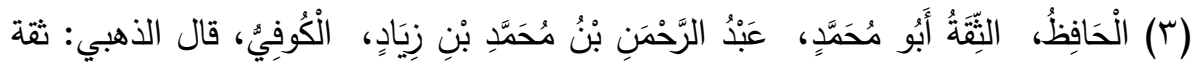

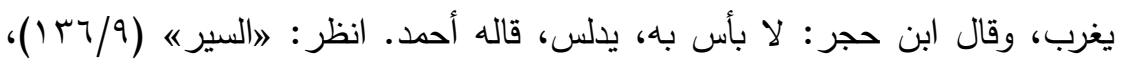

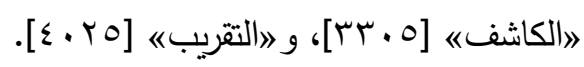

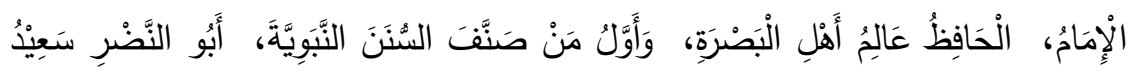

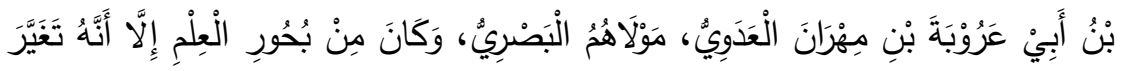

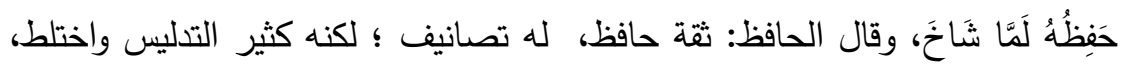

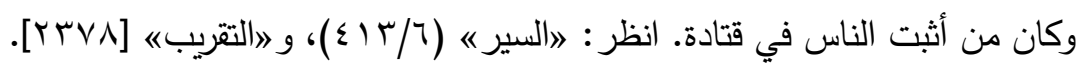

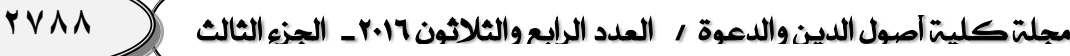




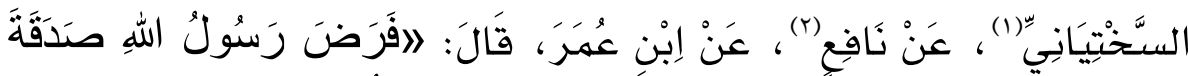

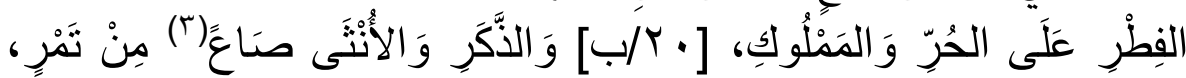

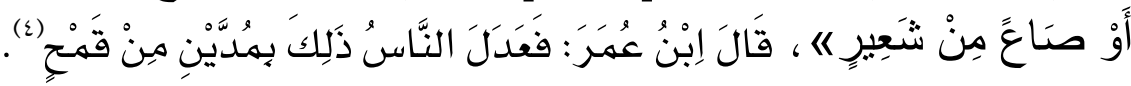

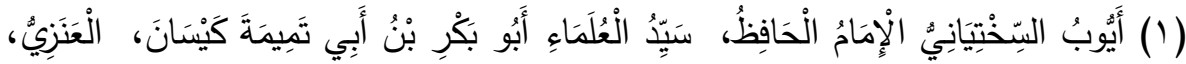

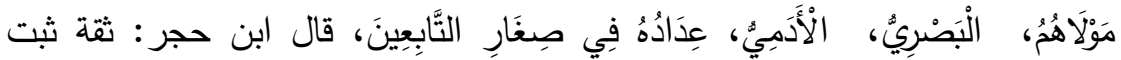

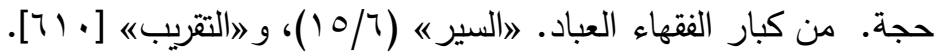

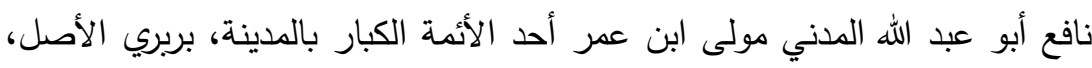

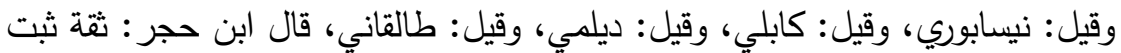

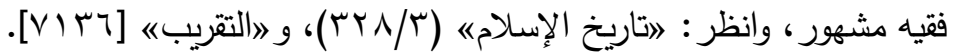
كذا في الموضعين: 》صاعه، وله وجه في العربية، وهو لغة ربيعة، ولا يزال المحدثون

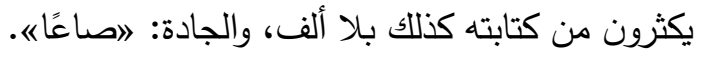

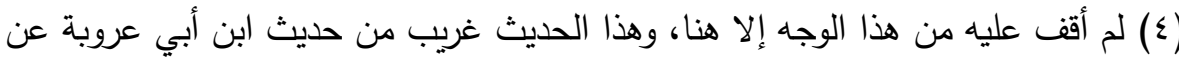

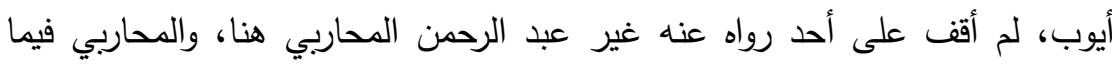

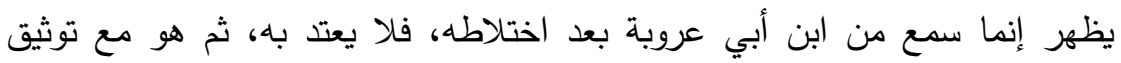

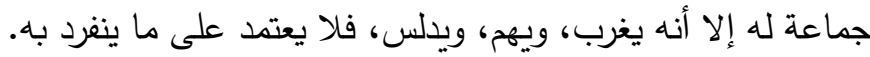
والحديث محفوظ من حديث أيوب، ولكن من غير طريق ابن أبي عروبة.

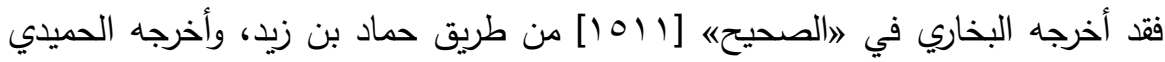

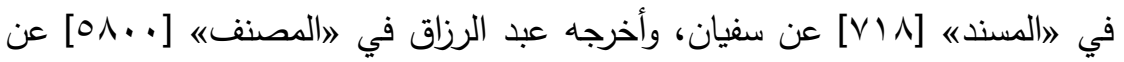

$$
\begin{aligned}
& \text { معمر ، ثلاثتهم عن أيوب، به. } \\
& \text { وتوبع أيوب عليه.= }
\end{aligned}
$$

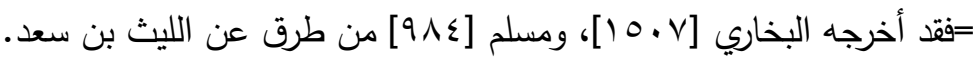




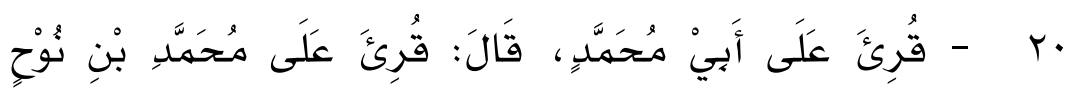

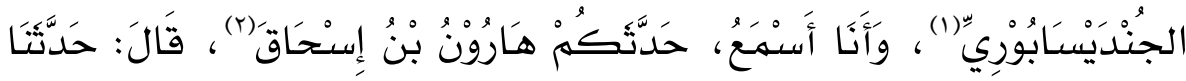

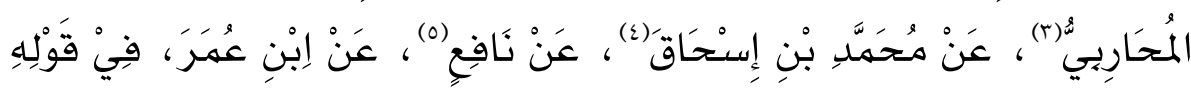

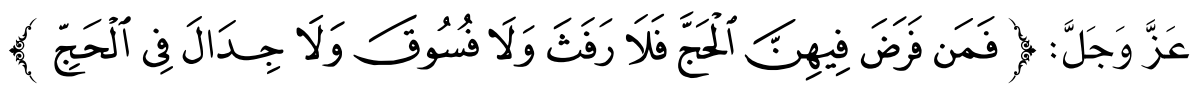

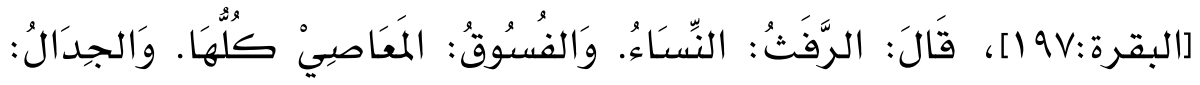

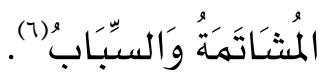

وأخرجه البيهقي في 》الكبير 《 [VVVI] من طريق الثوري، عن عبيد الله بن عمر، ويحيى بن سعيد.

ثلاثثه (الليث، وعبيد الله، ويحيى) عن نافع. وله طرق أخرى كثيرة مشهورة عن ابن

$$
\text { عمر، لا نطيل بذكرها، و الله أعلم. }
$$

$$
\begin{aligned}
& \text { (1) سبقت ترجمته في الحديث السابق [9 [1]. } \\
& \text { (Y) سبقت ترجمته في الحديث السابق [9] } \\
& \text { (r) سبقت ترجمته في الحديث السابق [9] }
\end{aligned}
$$

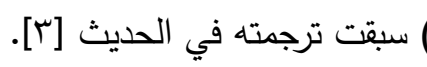

$$
\begin{aligned}
& \text { سبقت ترجمته في الحديث السابق [9 19]. }
\end{aligned}
$$

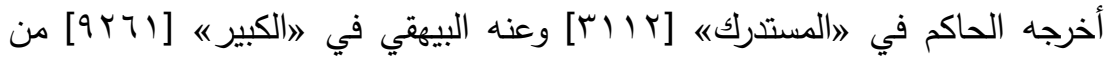

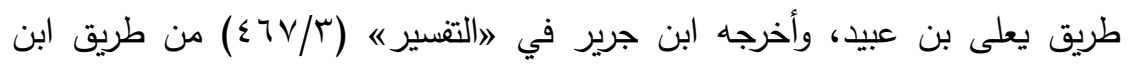

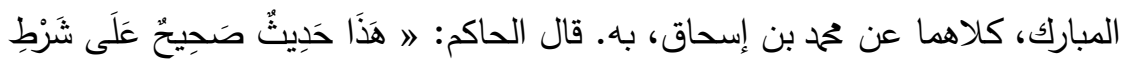

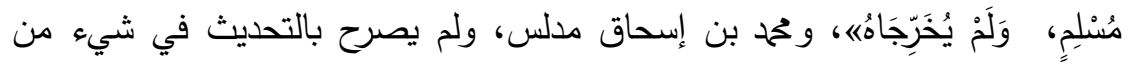

$$
\text { طرقه. }
$$




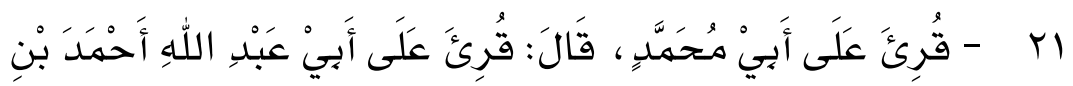

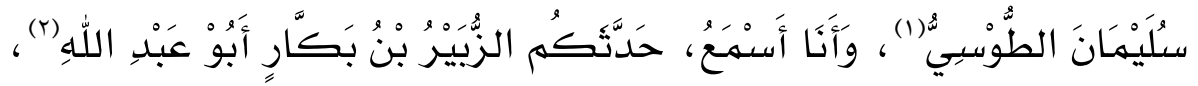

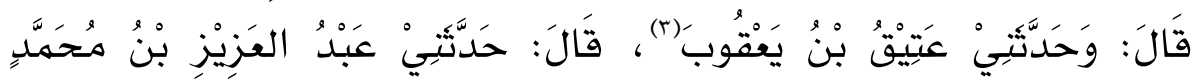

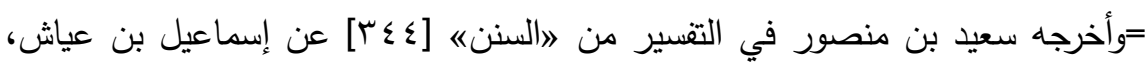
عن موسى بن عقبة، عن نافع. وهذا من رواية ابن عياش عن غير الثاميين وهي من

$$
\text { ضعيف حديثه. }
$$

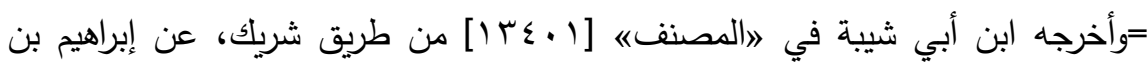
مهاجر ، عن مجاهد، عن ابن عمر، وسنده ضعيف، لحال شريك، وإبراهيم فكلاهما في

$$
\text { حفظه شيء. }
$$

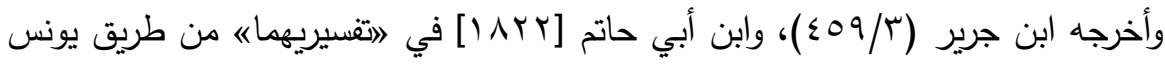
بن عبد الأعلى، عن ابن وهب، عن يونس بن يزيد، عن ابن عمر، وهذا إسناد

فالظاهر أن الحديث ثابت من قول ابن عمر، وإنما هو غريب من رواية المحاربي عن ابن إسحاق، وقد سبق أن المحاربي مع توثيق جماعة له إلا أنه يغرب، ويهم، ويدلس، فلا يعتمد على مفاريده، ولعله لذلك انتخبه الدارقطني هنا، و الله أعلم.

$$
\text { (Y) (Y) سبقت ترجمته في الحديث [^]. }
$$

(r) هو عتيق بن يعقوب بن صديق بن موسى بن عبد الله بن الزبير بن العوام، أبو يعقوب الزبيري المدني، وثقه الدارقطني، وذكر له في الرواة عن مالكه شيئا تفرد به، وهو ممن حفظ الموطأ في حياة ماللك، انظر: لاتاريخ الإسلامه (0/.بآ)، و السان

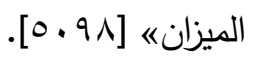




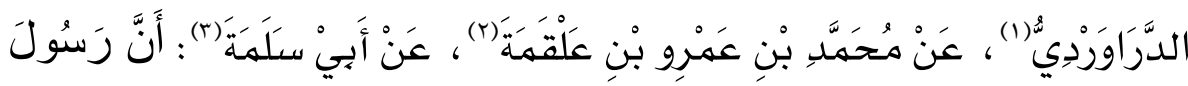

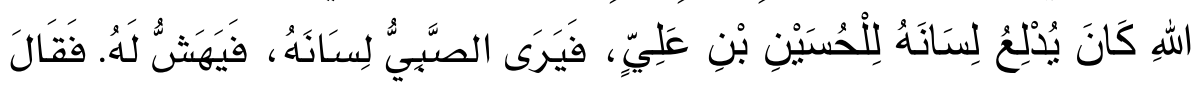

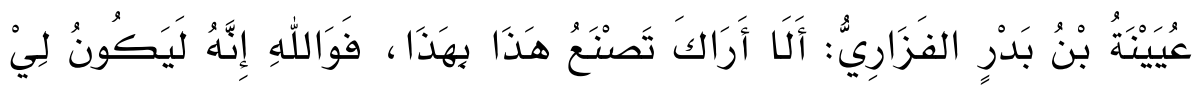

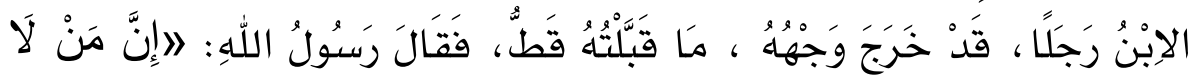

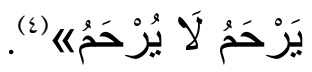

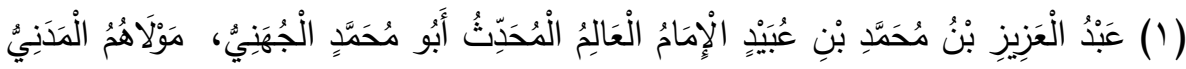

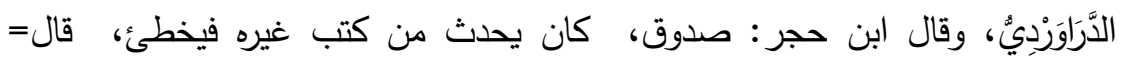

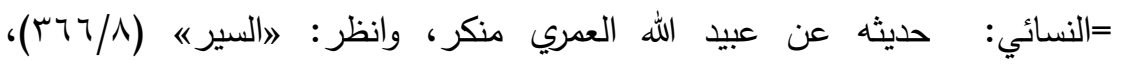

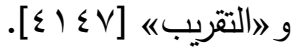

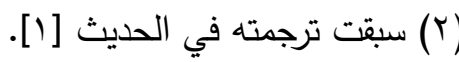

$$
\begin{aligned}
& \text { (1) سبقت ترجمته في الحديث [1]. }
\end{aligned}
$$

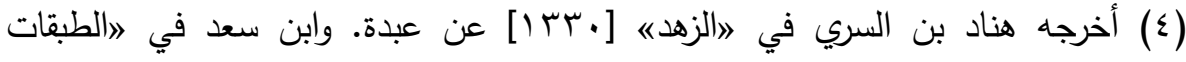

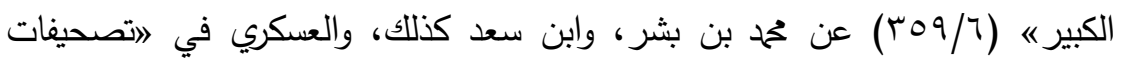

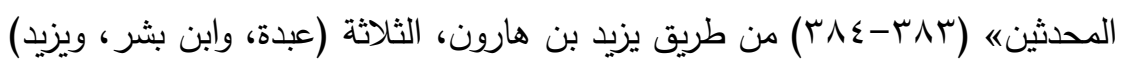

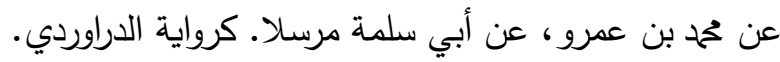

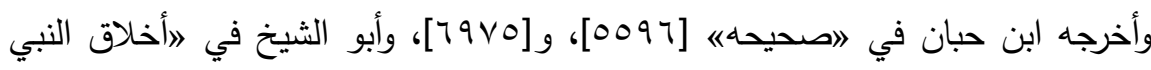

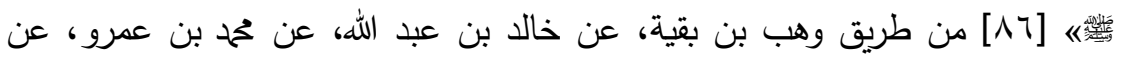

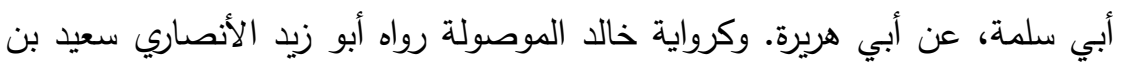

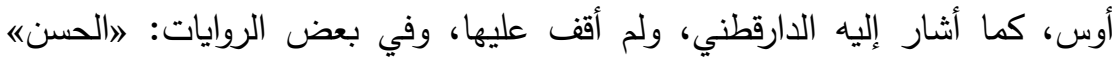

$$
\text { مكان 》الحسينه رضي الله عنهما. }
$$

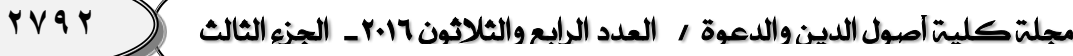

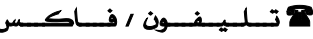




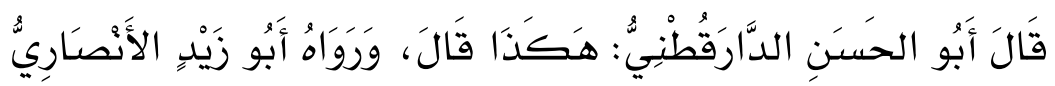

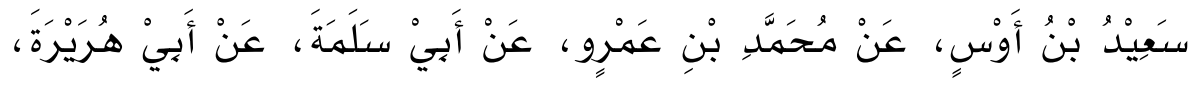

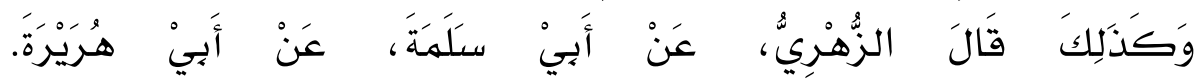

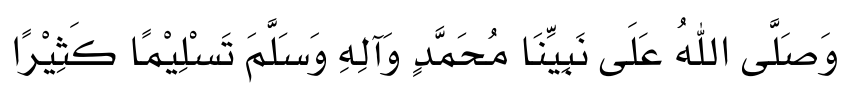

$=$

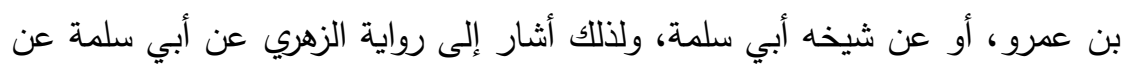

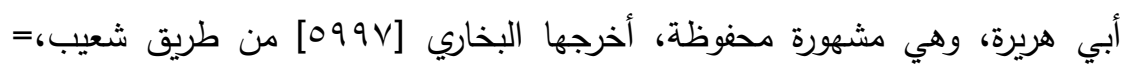

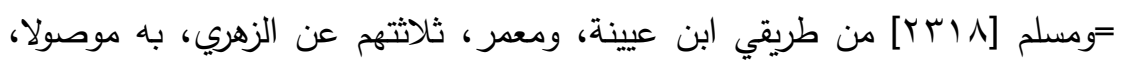

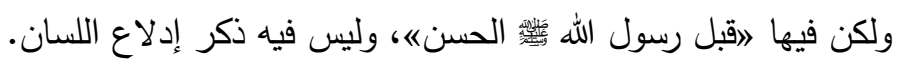

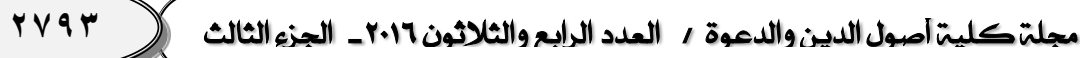




\section{الخاتمة - - مات}

\section{وفيدها أهم النتائج والتوصيات}

- ظهر من خلال هذا البحث تعدد طرق التصنيف عند المحدثين،

$$
\text { وأن من أهمها كتب الفوائد. }
$$

- وأن كتب الفوائد قوامها الانتخاب، ولا يقوم عادة بذلك إلا

$$
\text { أكابر الحفاظ الجامعين المطلعين. }
$$

- أن الإمام أبا الحسن الدارقطني من أشهر من قاموا بالانتخاب،

$$
\text { وقد انتخب كثيرا على شيوخ كثر. }
$$

- انتخب الدارقطني هِ هذا الجزء واحدا وعشرين حديثا من

غرائب حديث القاضي ابن معروف، وعامة هذه الأحاديث المنتخبة هنا

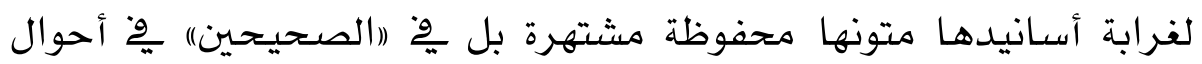
ككثرة. - عامة الغرائب المنتقاة هنا وقعت الغرابة فيها ِِّْ الطبقات الدنيا من الإسناد القريبة من المصنف، كشيوخ شيوخه أو شيوخهم، وليست أصل السند ، ولا طبقاته العليا. - تتوع المتفردون بهذه الأسانيد فتارة كانوا من الثقات لكنهم خالفوا من هم أوثق أو أكثر عددا، فصارت رواياتهم شاذة أو منكرة، وتارة كانوا من الضعفاء فرواياتهم من المناكير المردودة جزما. - الظاهر أن مجرد إطلاق وصف الغرابة مشعر بالضعف مون الجملة، حتى لو كانت من غرائب الثقات، مالم يضهم للغرابة وصف آخر

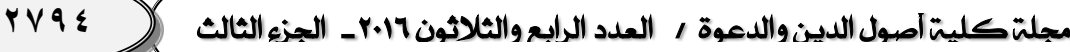

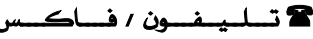


كالحسن، أو الصحة، فهذا الجزء على طرته بخط القاضي أبي يعلى ( فلى (الفوائد المنتقاة الغرائب))، بينها ترى جزءا آخر من انتقاء الدارقطني كذلك من حديث ابن معروف ولكنه موسوم بـ (الفوائد الحسـان المنتقاة).

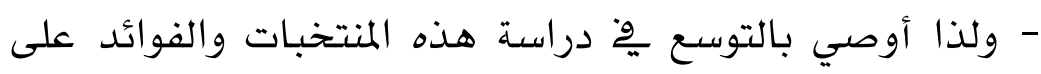

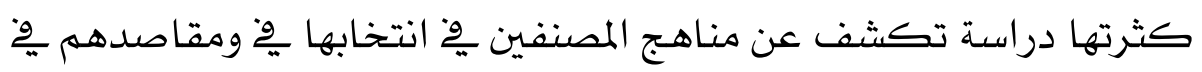
تتويعها.

والحمد لله أولا وآخرا، ظاهـرا وباطنا

وصلى الله على سيد الخلق محمد وسلهم تسليما كثيرا

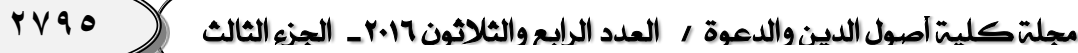




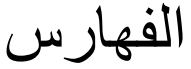

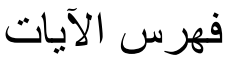

\begin{tabular}{|c|c|c|}
\hline رالحديث & الآسورة : & الآيح الكريمح \\
\hline$r$. & 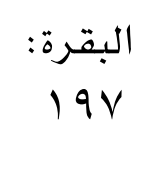 & 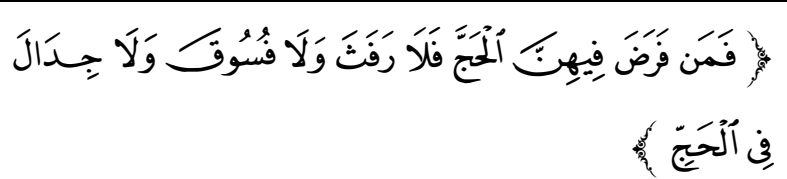 \\
\hline 10 & الفرقان: & 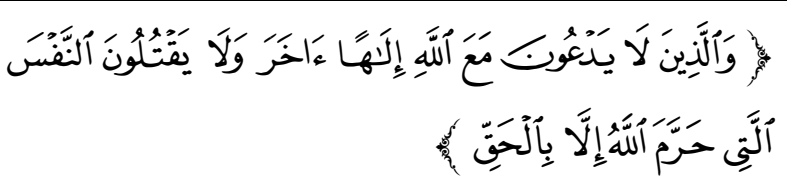 \\
\hline 11 & محمد : 19 & 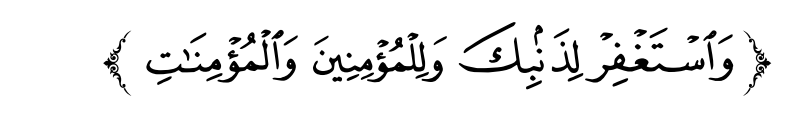 \\
\hline
\end{tabular}

** ******* *

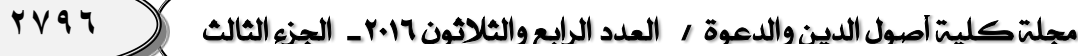


فرس الأحاديث:

\begin{tabular}{|c|c|c|}
\hline الحديث & الراوي & 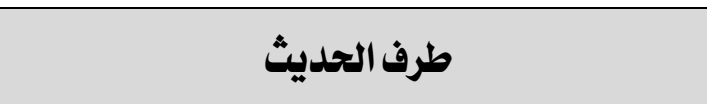 \\
\hline 7 & أبو هريرة & 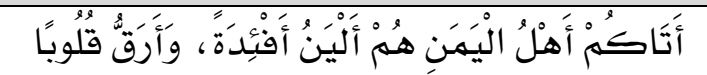 \\
\hline Ir & ابن عباس & 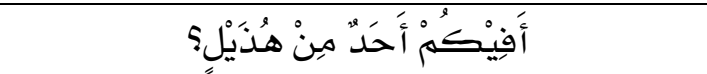 \\
\hline r & محمد بن مسلمة & 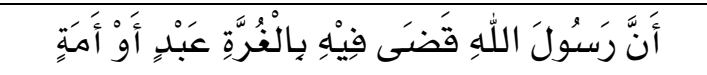 \\
\hline YI & أبو سلمة مرسـلا & 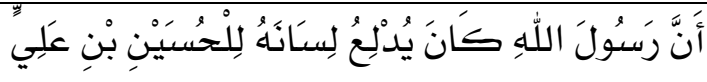 \\
\hline V & أسـامة بن عمير & أَنْ صتَلُوا فِيْ رِحَالِكُمْ \\
\hline 0 & عبد الله بن عكيم & 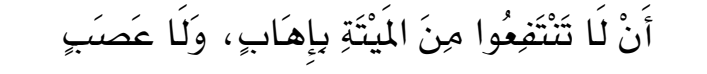 \\
\hline YI & أبو سلمة مرسـلا & 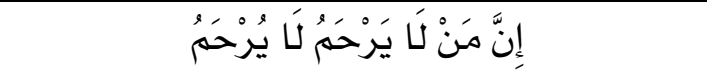 \\
\hline 1 & أبو هريرة & 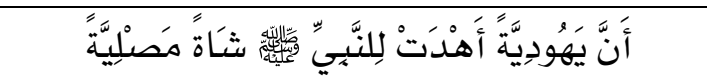 \\
\hline 1 . & 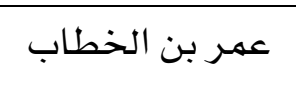 & 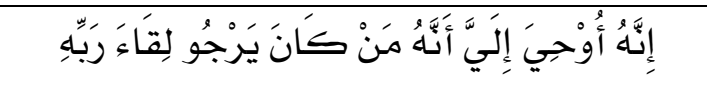 \\
\hline r & 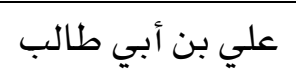 & 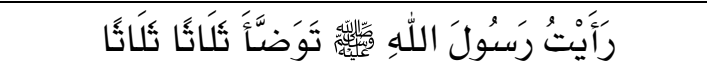 \\
\hline$r \cdot$ & ابن عمر موقوفا & الرَّفَثْ : النِّسَّاءُ. \\
\hline IV & 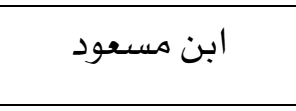 & 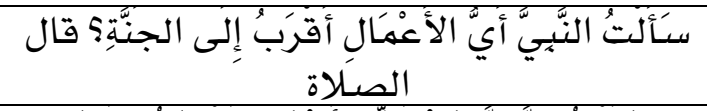 \\
\hline 10 & ابن مسعود & 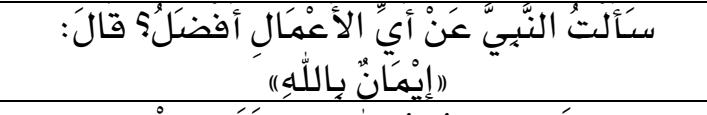 \\
\hline 19 & ابن عمر - ابر & فَرَضَ رَسَولُ اللَهِ صَدَقَةَ الفِطْرِ \\
\hline$\wedge$ & جابر & 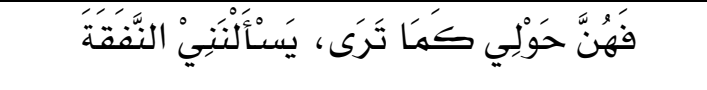 \\
\hline
\end{tabular}




\begin{tabular}{|c|c|c|}
\hline \multicolumn{2}{|c|}{ د. ماز ز بــن مهمــ بـن مهمد } & 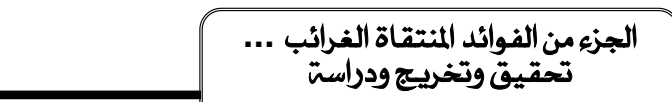 \\
\hline الحديث & 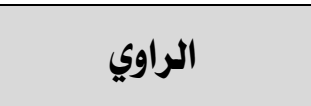 & طرف الحديث \\
\hline 1 & 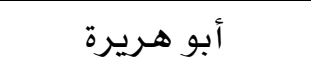 & 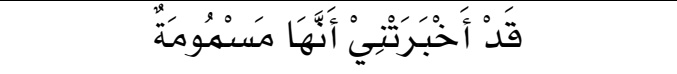 \\
\hline r & المفيرة بن شعبة & 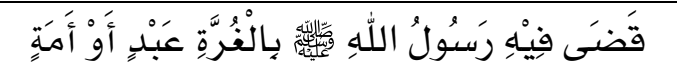 \\
\hline Ir & ابن عباس & 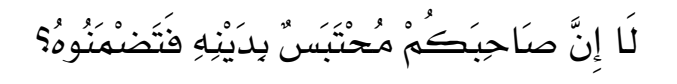 \\
\hline 9 & زيد بن أرقم & 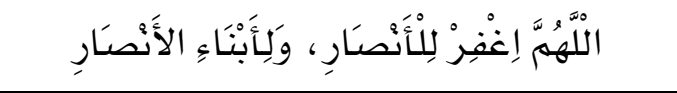 \\
\hline 1 & 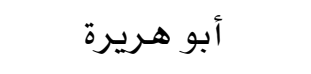 & مَاَ حَمَلَكلِ عَلَى مَا صَنَعْتِّى \\
\hline Ir & ابن عباس & 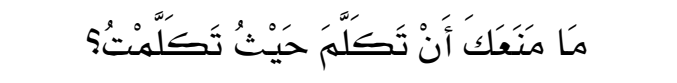 \\
\hline ir & 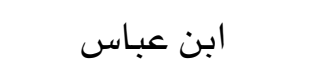 & 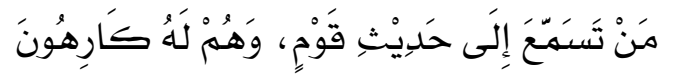 \\
\hline $1 \varepsilon$ & ابن عمر وأبو هرير & 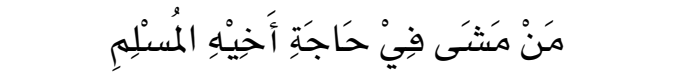 \\
\hline$\varepsilon$ & 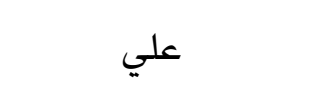 & 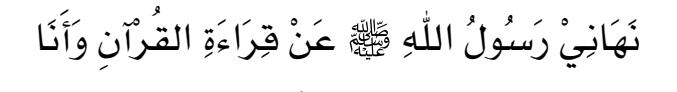 \\
\hline 11 & عبد الله بن & 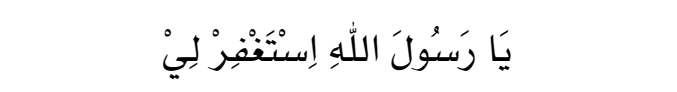 \\
\hline 17 & 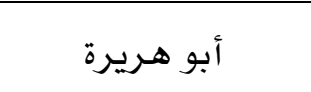 & 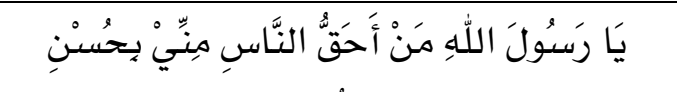 \\
\hline 11 & جابر & 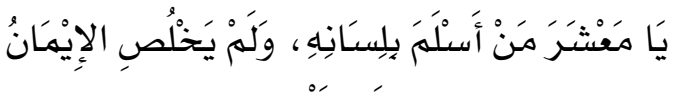 \\
\hline
\end{tabular}

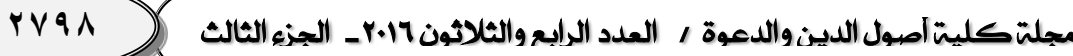


فرس الرو اة المتر جمون

\begin{tabular}{|c|c|}
\hline رقم الدلديث & 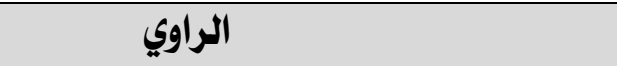 \\
\hline$\Lambda$ & 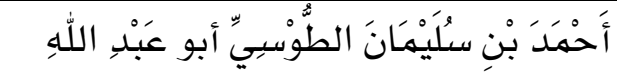 \\
\hline 1 & 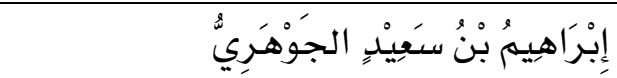 \\
\hline 17 & الأَحْوَصَ بْنُ جَوَّابِ الضَّبُِِّ \\
\hline V & أسـامة بن عمير \\
\hline 19 & أََيَّوبَ السنَخْتِيَانِيِِ \\
\hline Ir & \\
\hline Ir & بْنَ أبي المُغِيْرِة \\
\hline r & 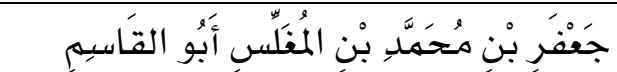 \\
\hline $1 \varepsilon$ & 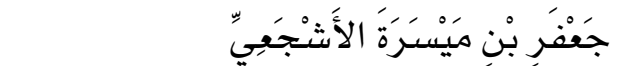 \\
\hline IY & حِبَّانُ بْنُ عَلِي العَنَرَ \\
\hline $1 \varepsilon$ & الحسَسَنْ بْنُ عَرَفَة \\
\hline Ir & الحُسَيْنْ بْنْ أَبَيْ زَيْدِ الدَّبَّاغُ \\
\hline 11 & 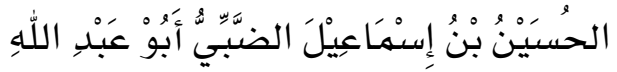 \\
\hline 10 & الحسسَيْنُ بْنُ الحسَسَنِ المَرْوزَِيٌُ 10 \\
\hline V & حَفْصُ بْنُ غِيَاتِ \\
\hline
\end{tabular}

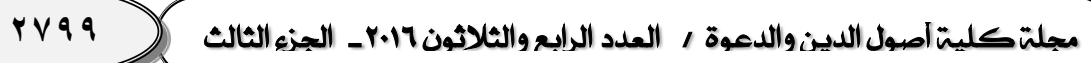


د. مـازن بــن محمسد بـن محمــ الجزي من الفوائد المنتقاة الغرائب ... تحقيق وتخريج ودراستشنلغان

\begin{tabular}{|c|c|}
\hline 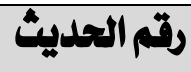 & 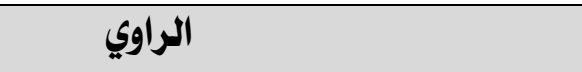 \\
\hline 0 & الحَكَكَم بن عتيبة \\
\hline$V$ & خَالِدٍ بن مهران الحَذَّاءِ \\
\hline 9 & خَلَّادُ بْنْ أَسَلْلَمَ \\
\hline 7 & 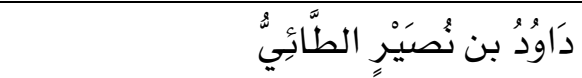 \\
\hline$\Lambda$ & 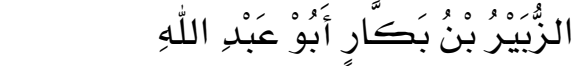 \\
\hline 19 & سسعيد بْنِ أَبِيْ عَرُوبَةً \\
\hline 1. & سَعِيدَ بْنْ المُسَيَّبَب \\
\hline Ir & سَعَيْدِ بْنِ جُبَيْرِ \\
\hline 1 & 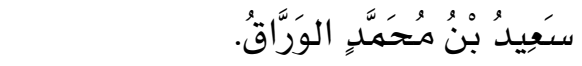 \\
\hline IV & 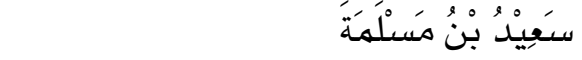 \\
\hline 10 & سُفْيَّانُ بْنُ عُيَيْنَة \\
\hline 11 & 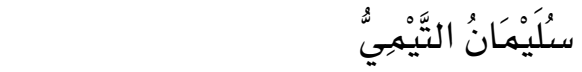 \\
\hline 7 & سليمـان بن مهران الأَعْمَشِ \\
\hline 11 & 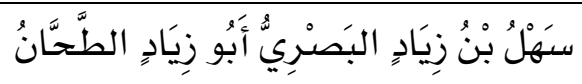 \\
\hline 0 & شُعبِة بن الحسجاج \\
\hline 11 & عَاصِِ الأَحْوَل \\
\hline
\end{tabular}

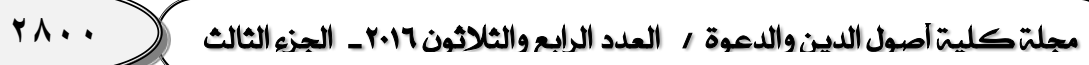


د. مLازj بسن محمسد بـن محمــ

الجزي من الفوائد المنتقاة الغرائب ... تحقيق وتخريج ودراستشنليان

\begin{tabular}{|c|c|}
\hline رقم الكدليّث & 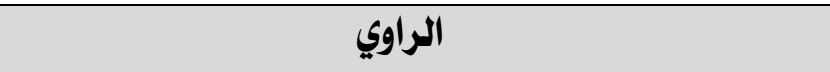 \\
\hline$\Lambda$ & عَبْدُ الجَبَّار بْنُ سَعِيدٍٍ المَسَسَاحِقِيٌٌ \\
\hline 0 & عبد الرحمن بن أبي ليلى \\
\hline 7 & عَبْدُ الرحمـن بْنُ أَبِيْ الْبَخْتَريِِ \\
\hline$\Lambda$ & عَبْدِ الرَحَحْهَنْ بْنَ أَبِي الزَِّّادِ ، \\
\hline 19 & عبد الرحهـن بن زيـاد المُحَارِيهُ \\
\hline YI & 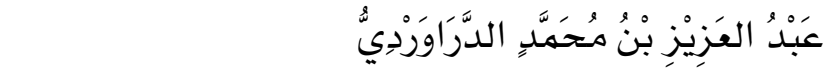 \\
\hline$\varepsilon$ & عَبْدِ الكَريمَ أَ \\
\hline$\varepsilon$ & عَبْدِ اللَهِ بْن الحَارثِ \\
\hline 11 & 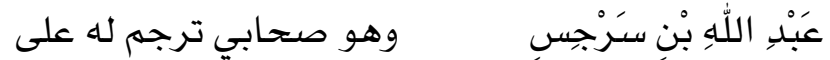 \\
\hline $1 \cdot$ & 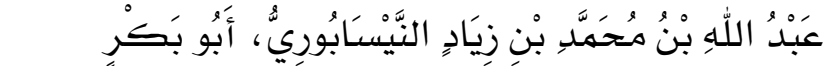 \\
\hline 11 & 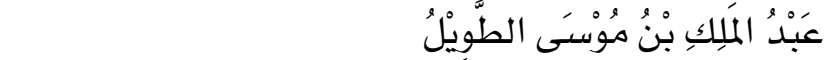 \\
\hline r & عَبْدَة بْنُ سُلَيْهَانَ \\
\hline$r$ & عُبِيْدِ اللَّهِ الخَوْنَانِيِّ \\
\hline 11 & عُبَيْدُ الللهِ بْنُ جَرَيْر بْن جَبَلَةَة \\
\hline Ir & عُبِيْدُ اللَهِ بْنْ غَنَّام \\
\hline
\end{tabular}

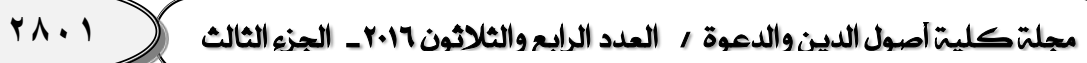


د. مـازن بــن محمسد بـن محمــ الجزي من الفوائد المنتقاة الغرائب ... تحقيق وتخريج ودراستشنلغان

\begin{tabular}{|c|c|}
\hline رقم الحدليث & 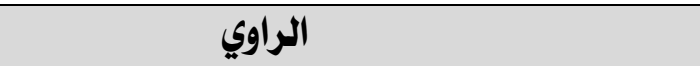 \\
\hline YI & عَتِيْقِ بْنُ يَعْقُوبَ \\
\hline r & عروة بن الزبير \\
\hline Ir & عِكرِمَةَّ مولى ابن عباس \\
\hline $1 \varepsilon$ & عَلِيهُ بْنُ ثَابِتٍ الجَزَرِيهُّ \\
\hline 17 & عَمَّارُ بْنْ رُزَيْتِ \\
\hline 17 & عُمَارَةَ بْنْ القَعْقَاعَ \\
\hline Ir & 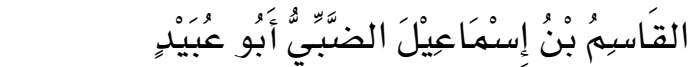 \\
\hline 9 & قَتَادَة بن دعامة \\
\hline 7 & 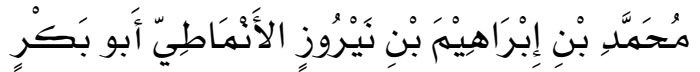 \\
\hline$r$ & مُحَمَسَّدِ بْنِ إِسْحَاقَ \\
\hline Ir & 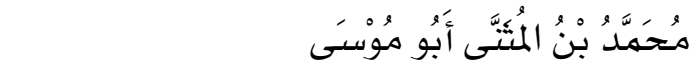 \\
\hline 0 & محمد بن جعفر غُنْذرَ \\
\hline 9 & 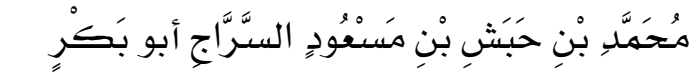 \\
\hline r & 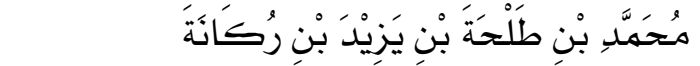 \\
\hline$\varepsilon$ & محمد بن عبد الرحمن إِبْنُ أَبِيْ لَيْلَى \\
\hline 11 & مُحَمَسَّلُ بْنُ عَمَرِورِبْنُ جَبَلَة \\
\hline
\end{tabular}

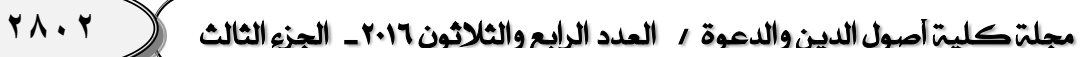


د. مـازjز بــ مهمسد بــ مهمــ الجزي من الفوائد المنتقاة الغرائب ... تحقيق وتخريج ودراستشنانيان

\begin{tabular}{|c|c|}
\hline رقم الحديشي & الراوي \\
\hline 1 & مُحَمَّدُ بْنُ عَمَرِور بن علقهمة. \\
\hline$\Lambda$ & محمد بن مسلم بن تدرس \\
\hline 19 & 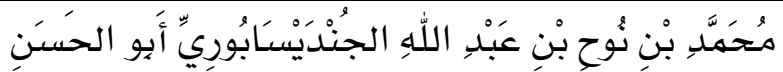 \\
\hline$r$ & 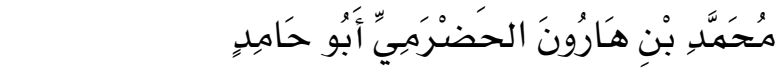 \\
\hline 7 & مُصنعَبَ بْنُ المِقدَامَام \\
\hline$\Lambda$ & مُوسَى بْنِ عُقِبَةَ ، \\
\hline $1 \varepsilon$ & رة الأشـج \\
\hline 19 & نَافِعِ مولى ابن عمر \\
\hline 9 & 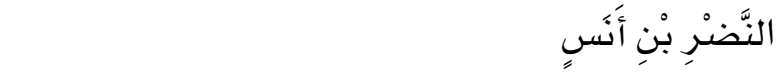 \\
\hline 9 & النَّضْرَ بن شْهَيْلِ \\
\hline r & هَارُونُ بْنُ إسنْحَاقَ الهَهْدَانِيُّ \\
\hline 11 & هُدْبَة بْنْ المِنْهَالِ \\
\hline r & هِشَامَ بْنِ عُرْوَةً \\
\hline 11 & هِلَالُ بْنُ بـشْرِ \\
\hline IV & الوَلِيدَ بْنَ العَيْزَارِ \\
\hline 1 & 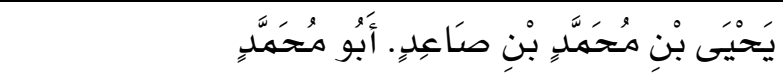 \\
\hline
\end{tabular}

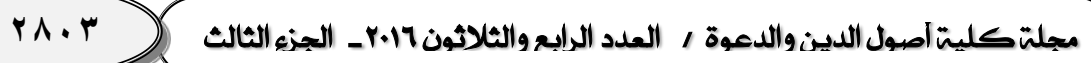


د. مـازن بـن محمسد بـن محمــ الجزيء من الفوائد المنتقاة الغرائب ... تحقيق وتخريج ودراستشنلغان

\begin{tabular}{|c|c|}
\hline رقم الحدليث & 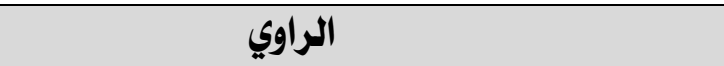 \\
\hline$r$ & 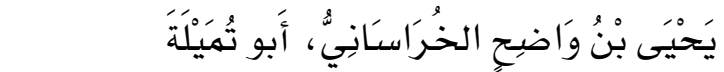 \\
\hline $1 \varepsilon$ & يَعْقُوبَ بْنْ إبِرَاهِيْمَ البَزَّاز، أَبو بَكُرِ \\
\hline$\varepsilon$ & يَعْقُوبُ بْنُ إبْرَاهِيَمَ، أَبَو يُوسُفَ القَاضِي \\
\hline 0 & 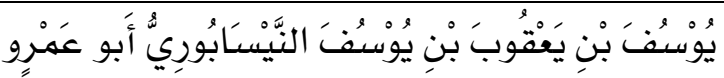 \\
\hline$\wedge$ & أَبو الزُبِيْرِ ، هو محمد بن مسله \\
\hline V & أبو الملِيح هو ابن أسـامة بن عمير \\
\hline 0 & 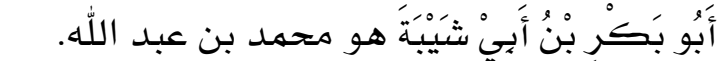 \\
\hline 17 & أبو زُرْعَةَ بن عمرو بن جرير \\
\hline 1 & أَبَو سَلَمَتَّة بن عبد الرحهن. \\
\hline 7 & أبو صَالِحِح هو ذكوان الســان \\
\hline 10 & أبو عَمْرِور الشَّيَّانِيِِّ هو سعيد بن إياس. \\
\hline $1 \cdot$ & 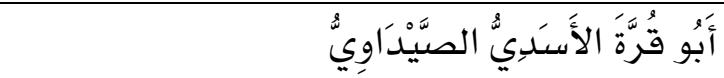 \\
\hline IV & أَبْو يَعْفورِ هو عبد الرحمن بن عبيد \\
\hline$\varepsilon$ & أَبُو يُوسُفَ القَاضِي هو يعقوب بن إبراهيم \\
\hline
\end{tabular}

فهرس المصادر و المر اجع

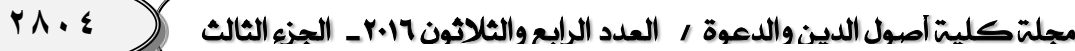


1 القرطبي ابن عبد البر. تحقيق محمد علي البجاوي، تصوير دار المعرفة. r - - الإصابة يخ تمييز الصحابة : لأحمد بن علي بن حجر العسقلاني. (أ) تحقيق محمد علي البجاوي، تصوير دار المعرفة. (ب) تحقيق الدكتور عبد الله التركي، طبعة دار هـر.

r - أطـراف الغرائبب والأفـراد، لابـن طـاهـر المقدسـي. الطبعـة الأولى لدار الكتب العلمية.

ع -الأمـالي : لابن بشـران، تحقيق: عـادل بـن يوسـف العـزازي. الطبعـة الأولى. دار الوطن.

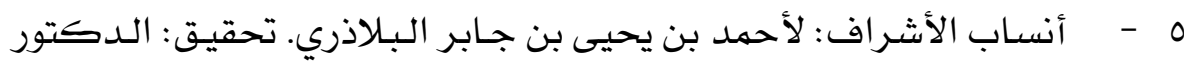
محمد حميد الله. دار المعارف - بهصر.

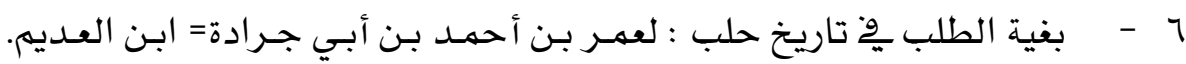
تحقيق: الدكتور سهيل زكار. الطبعة الأولى، دار الفكر - بيروت.

V - - V - V الذهبي. تحقيق: أ - عمر عبدالسـلام تدمري. الطبعة الأولى (V) ع اهـ - وما بعدها ). دار الكتاب العربي -بيروت. ب - بشـار عواد معروف. الطبعة الأولى، دار الغرب الإسـلامي.

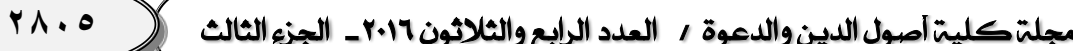


1 - تاريخ أسهـاء الثقات : لأبي حفـص عمـر بـن أحمـد بن عثمـان ابن شـاهـين.

تحقيق: صبحي السـامرائي. الطبعـة الأولى (ع • ع ا هـ). الـدار السـلفية -

الكويت.

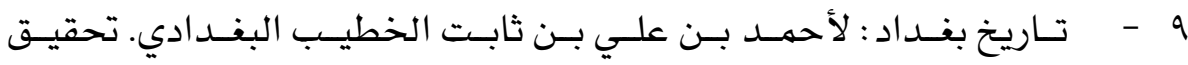
الـدكتور : بشـار عـواد معـروف. الطبعـة الأولى (r بع اهـ). دار الغـرب

$$
\text { الإسـلامي، بيروت . }
$$

• 1 - تاريخ خليفة بن خيـاط. تحقيـق: الـدكتور أكـرم ضياء العهـري. الطبعـة

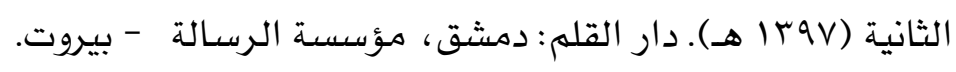

11 عساكر: تحقيق عمر بن غرامة العمروي، دار الفكر، بيروت، الطبعة

$$
\text { الأولى، سنة (10 ألهـ - 1990). }
$$

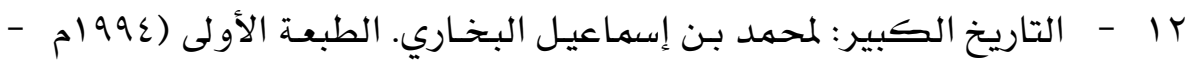
9VA ام). مطبعـة دار المعـارف العثمانيـة - الهنـد. تصسوير دار الفكـر بيروت.

سا - تخريج الأحاديث والأثار الواقعة وِّ تفسير الكشـاف للزمخشري: لجمـال الدين أبي محمد عبـدالله بـن يوسـف بـن محمـد الزيلعي بتقـديم الثـيخخ: عبدالله بن عبدالرحمن السعد. وبعناية سلطان بن فهد الطبيشي. الطبعـة

$$
\text { الأولى (ع اع اهـ) دار ابن خزيهة. }
$$

عا - تقسـير القـرآن العظـيم: مســـدا عـن رســول الله والصــحابة والتـابعـين: للحــافظ عبـدالرحمن بـن محمــد بـن إدريسس الـرازي= ابـن أبسي حـاتم :

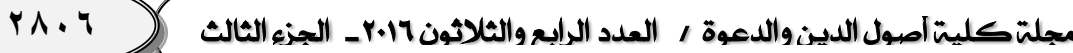


تحقيق: أسعد محمد الطيب - الطبعة الأولى (VIV إنه - 199V م) إعداد : مركز الدراسـات والبحوث بمكتبة نزار الباز.

10 - تقريـب التهذيب: لأحمـد بـن علي بـن حجـر العسـقلاني. تحقيقق: محمــ

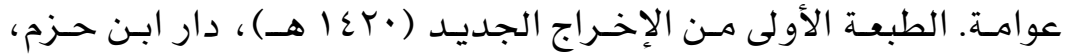

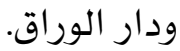

17 - التمهيد لما بٍِّ الموطأ من المعاني والأسـانيد : لأبي عمـر يوسـف بـن عبــالله

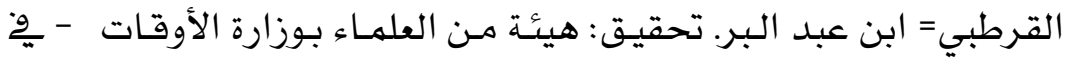

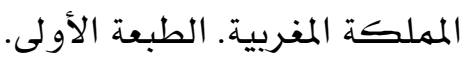

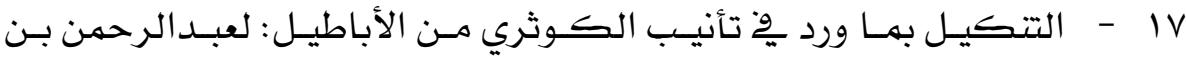

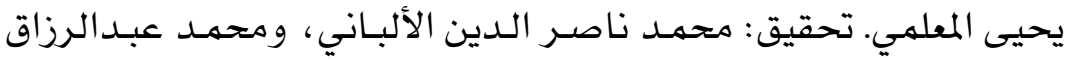
حمزة. طبع إدارة البحوث والإرشاد ، بالسعودية.

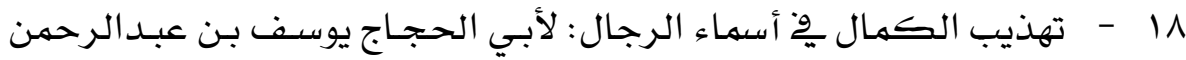

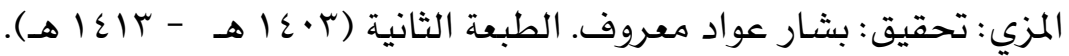

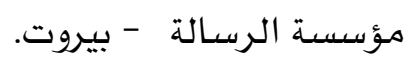

19 - الثقـات: لأبسي حـاتم محمهـ بـن حبـان البسـتي. تحست مـراقبـة : الـدكتور

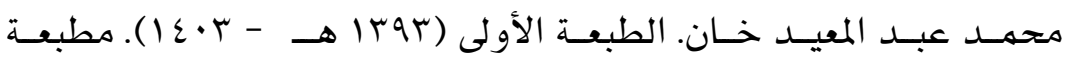

$$
\text { مجلس دائرة المعارف العثمانية - الهند. }
$$

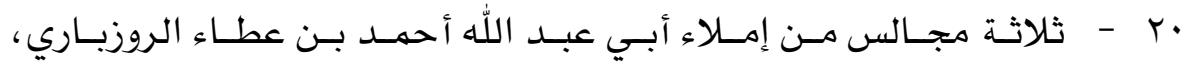
مخطوط، برنامج جوامع الكلم.

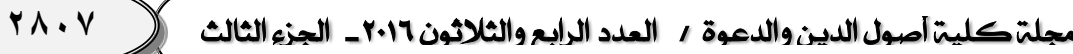


ا Y جامع المسـانيد والسنن: لابن كثير. تحقيق د عبد الملك دهيش. الطبعـة

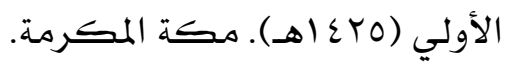

r - - الجرح والتعديل: لأبي محمد عبد الرحمن بن محمد بن ادريس (ابن أبي

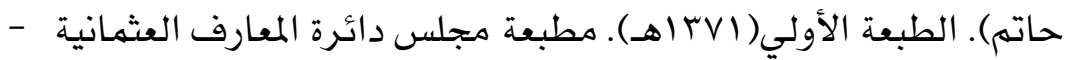

$$
\text { الهند. تصوير دار احياء التراث العربي - بيروت. }
$$

Tr - حلية الأولياء وطبقات الأصفياء: لأبي نعيه أحمد بن عبد الله الأصبهاني.

$$
\text { تصوير دار الفكر. }
$$

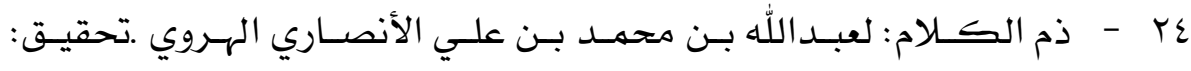

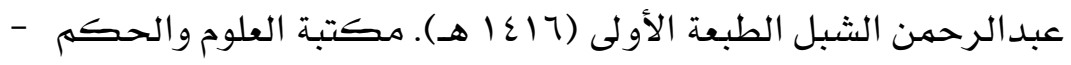

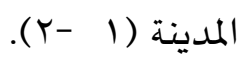

ro - الزهد : لوكيع بن الجراح. تحقيق: عبدالرحمن بن عبدالجبار الفريوائي.

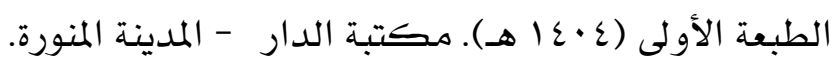

Tr - السنن: لعلي بن عمر الدارقطني: تصسحيح وترقيم السـيد عبـدالله هـاشـم يماني المدني. تصوير دار الكتب العلمية - بيروت.

rV - - TV

(أ) تحقيق حسن عبد المنعمى ، بإشـراف الشيخ شـعيب الأرناؤوط. الطبعـة الأولى. مؤسسة الرسـالة.

(ب) تحقيـق: دكتـور عبـدالغفار البنـداري، وسـيد كســروي. الطبعـة

$$
\text { الأولى (1اعا هـ). دار الكتب العلمية - بيروت. }
$$

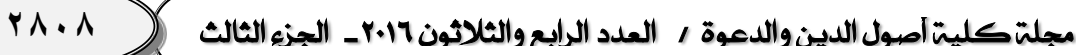


YN - السنن الكبير: لأبي بكر أحمد بن الحسـين البيهقي.

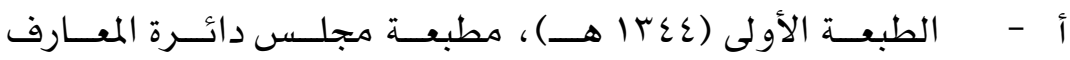

$$
\text { النظامية، الهند. تصوير دار المعرفة -بيروت. }
$$

ب - تحقيق الدكتور عبد الله التركي، دار هـر.

r9 - سير أعلام النبلاء: لمحمـد بن أحمـد بن عثمـان الذهبي. تحقيق: شعيب

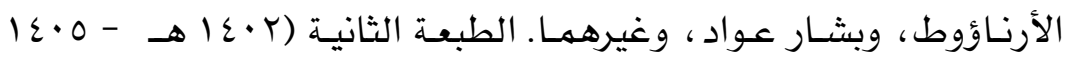

$$
\text { هـ) . مؤسسة الرسالة - بيروت. }
$$

•r - - شرح السنة : لمحيي السنة أبي محمـد الحسـين بن مسعود الفـراء البغوي.

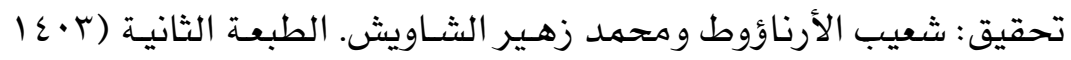

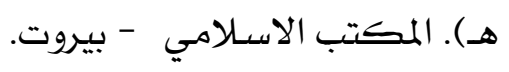

اس - الضعفاء: لأبي جعفر محمد بن عمرو بن موسـي العقيلي، تحقيق: مـازن

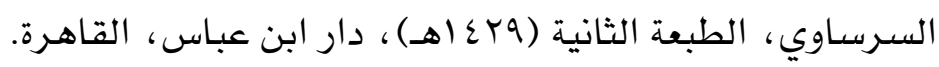

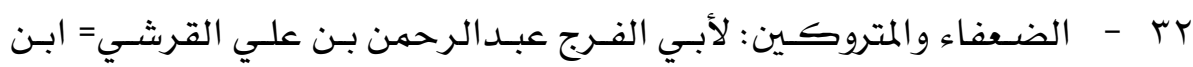

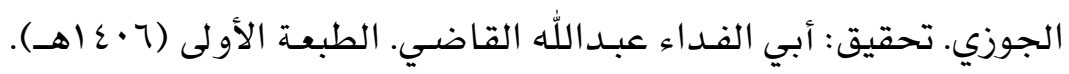

$$
\text { دار الكتب العلمية - بيروت. لجوين. }
$$

$$
\text { rr أ - الطبقات الكبرى: لمحمد بن سعد كاتب الواقدي: }
$$

(ب) تحقيـق: زيـاد محمــد الطبعـة الثانيـة (1 •ع ا هــ). مكتبــة العلـوم

$$
\text { والحكم. المدينة المنورة. }
$$

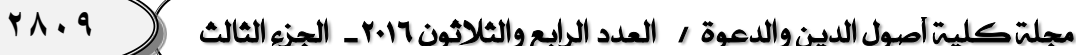


(ج) تحقيق: د. محمد بن صامل السلهي. الطبعة الأولى (عاعـاهـ). مكتبـة

$$
\text { الصديق - الطائف. }
$$

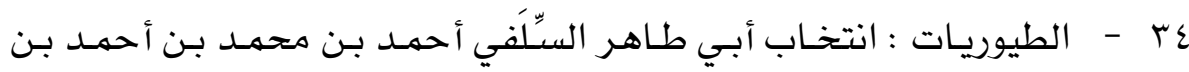

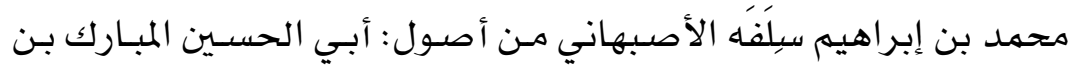

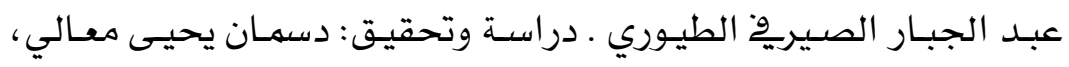

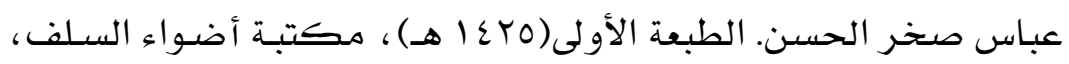
الرياض.

ro - العلل: للدارقطني علي بن عمـر. تحقيق: الـدكتور محفوظ الرحمن زيـن

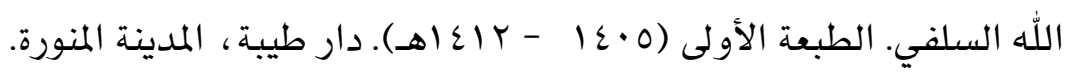
بr - - العلل ومعرفة الرجال: للإمام أحمد بن محمـد بن حنبـل (رواية ابنها عبـد الله بن أحمد عنها).

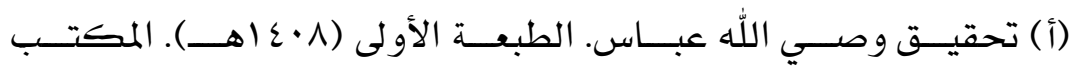

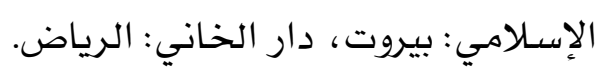

(ب) تحقيق الدكتور طلعت قوج بيكيت، والدكتور إسماعيل أوغلي، الطبعة الأولى (191VV م)، المكتبة الإسـلامية ، استانبول، تركيا. rV - العلل ومعرفة الرجال: للإمام أحمد بن محمـد بن حنبل. (بروايـة المروذي

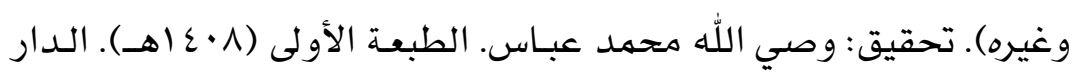

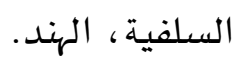




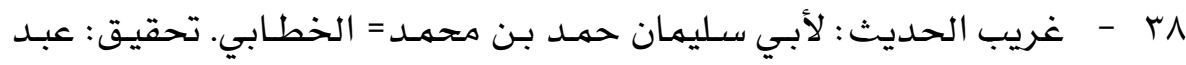
الكريم بن إبراهيم العزباوي. الطبعة الأولى (ب ·ع ا هـ - r.ع أهـ). دار

$$
\text { الفكر - دمشق. }
$$

qr - فضائل مصر وأخبارها وخواصها ، للحسـن بن إبراهيم بن الحسـين ابن زولاق، طبعة خاصة لمكتبة الأسـرة (9 اع اهـ) دار الخانجي، القاهرة.

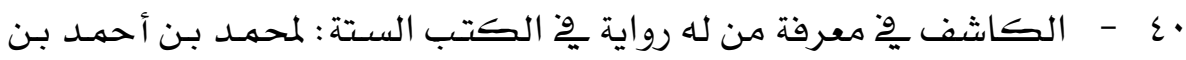
عثمـان الذهبي: قدم لله وعلق عليه محمـد عوامـة ، وخـرج نصوصسه أحمـد نهـر الخطيـب. الطبعـة الأولى (باع أهـ). دار القبلـة -مؤسسـة علـوم القرآن.

اع -الككامل يخ ضعفاء الرجال، لأبـي أحمـد عبـد الله بن عـدي الجرجـاني، اعتتى بـه مـازن بن محمـد السـرسـاوي، الطبعـة الثانيـة (هبع اهـ) مكتبـة

$$
\text { الرشد. }
$$

rع - كشف الأستار عن زوائد البزار : لنور الدين علي بن أبي بكر الهيثهـي. تحقيق: حبيب الرحمن الأعظمـي. الطبعة الأولى (99 ا1 هـ - 0. • اهـ).

$$
\text { مؤسسة الرسسالة - بيروت. }
$$

بع - الكشـف الحثيـث عمـن رمسي بوضـع الحـديث : لبرهــان الـدين الحلبـي سبط ابن العجـمي. تحقيق: صبحي السـامرائي. مطبعة العاني - بغداد. عـ - الكنى والأسماء: لأبي بشر محمد بن أحمد بن حمـاد الـدولابي. تحقيـق:

$$
\text { نظر الفاريابي. الطبعة الأولى. دار ابن حزم. }
$$

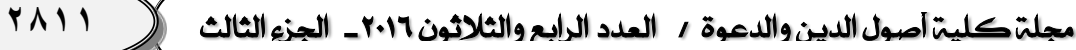


0ع - اللآلئ المصنوعة: لجلال الدين السيوطي. الطبعة الأولى، مصورة عنها يو

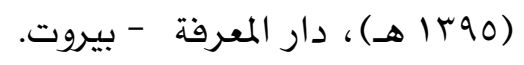

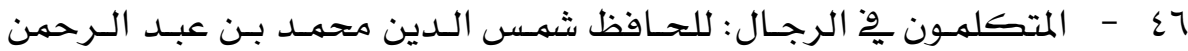
السخاوي، ضمن مجموع (أريع رسائل بِّ علوم الحديث) بتحقيق: الثـيخ

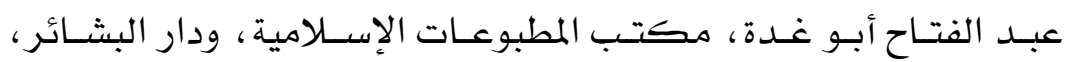

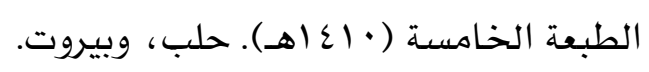

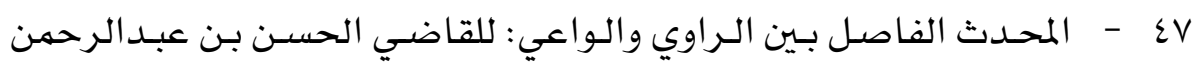
الرامهرمزي. تحقيق: د. محمد عجاج الخطيب. الطبعة الثالثة (ع •ع أهـ).

$$
\text { دار الفكر - بيروت. لمهري. }
$$

1ع - مختصر زوائد مسند البزار على الكتب الستة ومسند أحمد : لأحمد بن علي بن حجر العسقلاني. تحقيق: صبري بن عبد الخـالق أبي ذر. الطبعـة الطبـ

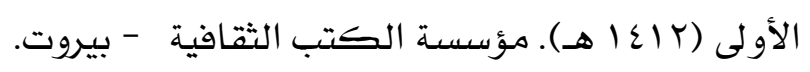

29 - مستخرج أبي عوانة (يعقوب بن إستحاق الإسفراييني) على صسيح مسـلم. تحقيق: أيمن عارف الدمشقي. الطبعة الأولى. دار المعرفة ، بيروت.

0 - مسند البزار (البحـر الزخـار) لأحمـد بن عمـرو بـن عبـالخالق العتكي.

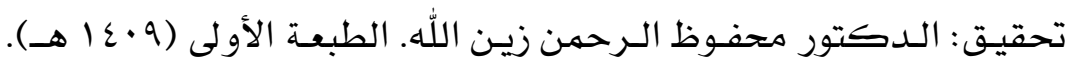

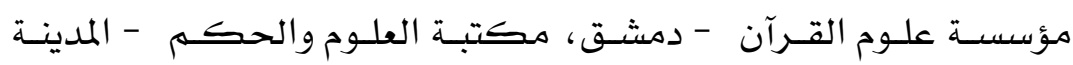
المنورة.

ا 01 - مشيخة الإمام أبي حفص عمر بن الحسن المراغي، تخريج: صدر الدين

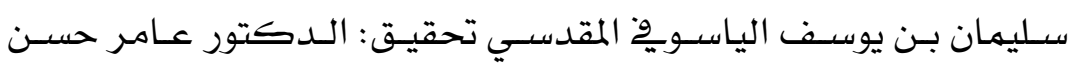


صبري الطبعـة الثانيـة (7rعا هـ). دار البشـائر الإسـلامية (ضـمن سلسـلة

$$
\text { لقاء العشر الأواخر (Or) ). }
$$

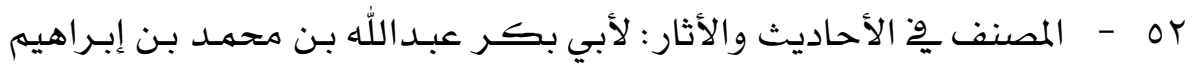

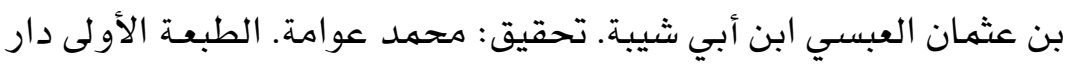

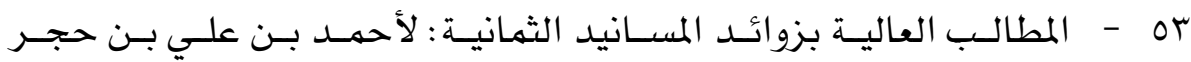
العسقلاني: تحقيق: مجموعة من طلبة العلم، بإشراف وتتسيق الدكتور:

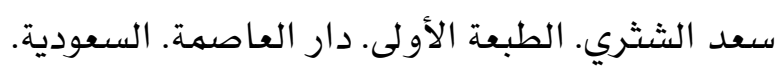

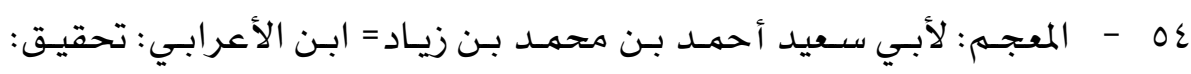

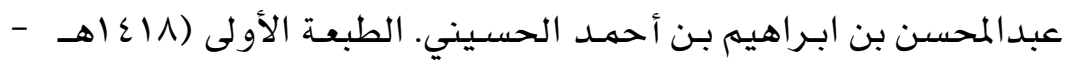
(199V م م). دار ابن الجوزي - السعودية.

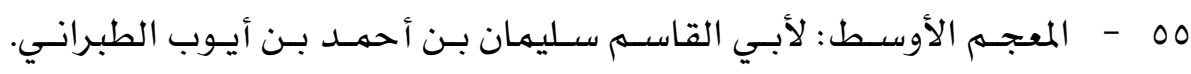

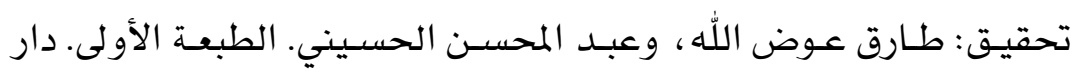
الحرمين، مصر.

07 - معجم الصحابة: لأبي القاسهم عبد الله بن محمد البغوي. دراسة وتحقيق:

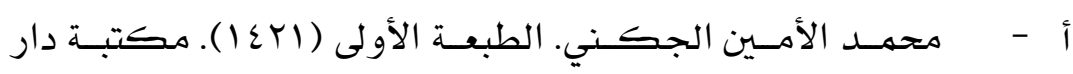

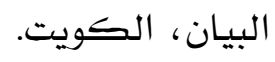

ب - محهـــ عـوض المنقـوش، إبـراهيم إسهاعيـل القاضـي. الطبعـة الأولى، مبرة الآل والأصحاب، الكويت.

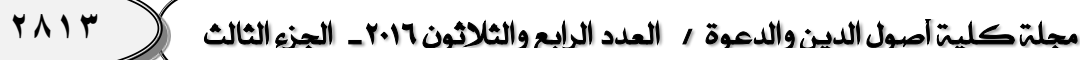

ت تــــــــون / فـاكسن 
oV - - oV حمــي عبدالمجيـد السـلفي. · الطبعـة الأولى (9 ابا هـ) ، الـدار العربيـة للطباعة - بغداد، مصورة دار البيان بالقاهرة. 01 - معرفة الصحابة: لأبي نعيم أحمد بن عبد الله بن أحمد الأصبهاني . (أ) تحقيـق: د. محمهد راضـي بـن حـاج عثمـان. الطبعـة الأولى (1 ·ع ا هـ). مكتبة الدار: المدينة المنورة، مكتبـة الحرميـن: الرياض. (ب) تحقيق: عادل بن يوسف العزازي. الطبعة الأولى. دار الوطن ـ السعودية. 09 معرفة الصحابة: لأبي عبدالله محمد بن إسـحاق بن محمـد بن يحيـى بن منــده. تحقيـقت: الــدكتور عــامر حسـن صــبـري. الطبعـة الأولى ســنة

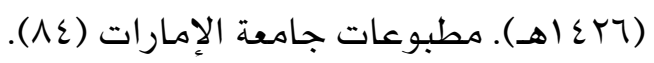

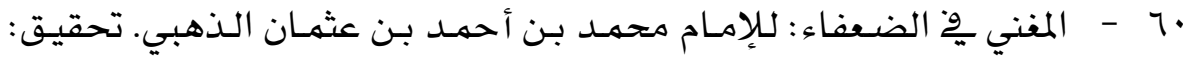
نورالدين عتر.

ال - من ككلام أبي زكريا يحيى بن معين يخٌ الرجال: رواية أبي خالـد الـدقاق يزيد بن الهيثم بن طهمان البادي. تحقيق: د. أحمـد محمـد نـور سـيف. دار

$$
\text { المأمون للتراث، دمشق - بيروت. }
$$

با - الموضـوعات: لأبـي الفـرج عبـد الـرحهن بـن علـي القرشـي= ابـن الجـوزي.

$$
\text { تحقيق: }
$$

تحقيق نور الدين بن شكري بن علي بوجيـلار، الطبعة الأولى (1 (اء اهـ). دار أضواء السلف، الرياض.

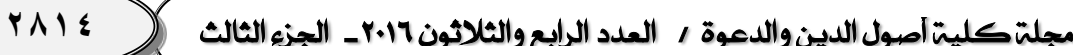




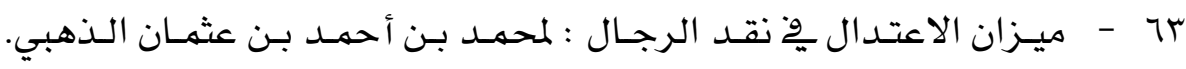

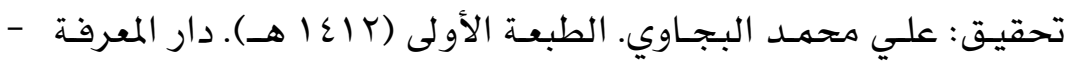

$$
\text { بيروت. }
$$

ع7 - النفقة على العيال: لعبد الله بن محمد بن عبيد القرشي ابن أبي الـدنيا .

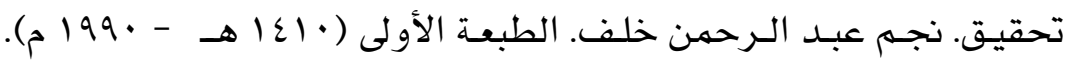
دار ابن القيم، الدمام، السعودية.

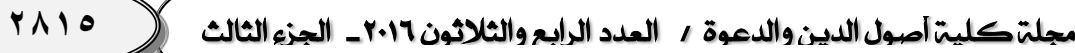




\begin{tabular}{|c|c|c|}
\hline ن مـ & 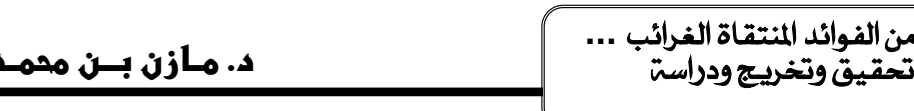 & 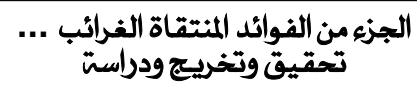 \\
\hline \multicolumn{3}{|c|}{ فهرس الموضو عات } \\
\hline الصفحة & 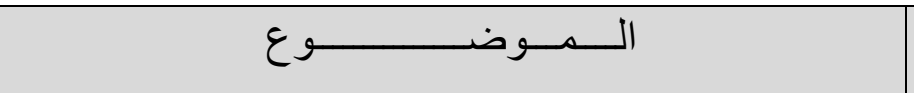 & s \\
\hline TVIY & 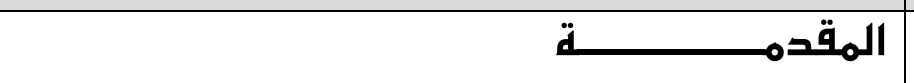 & $*$ \\
\hline$r V 10$ & سمي الدراســـة & \\
\hline rV17 & 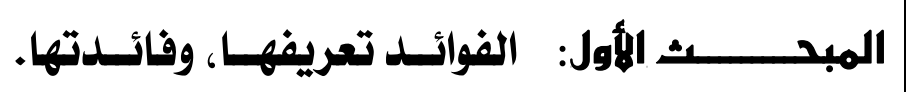 & $*$ \\
\hline TVIT & 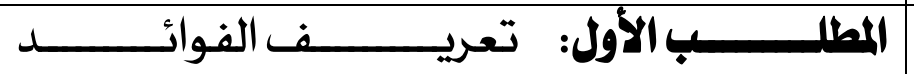 & \\
\hline TVY. & 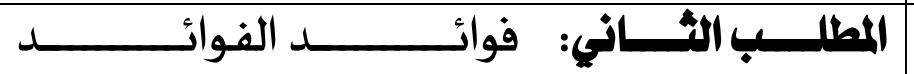 & \\
\hline TVYI & 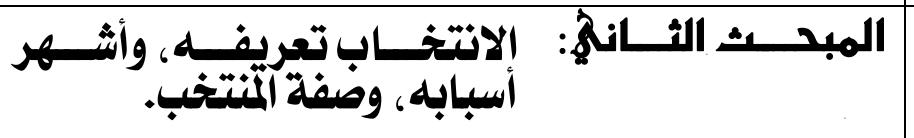 & $*$ \\
\hline TVYI & 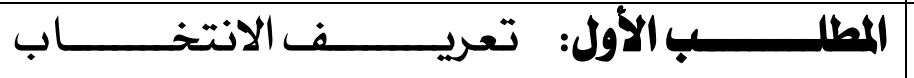 & \\
\hline TVYI & 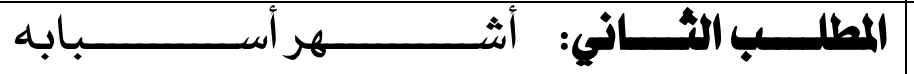 & \\
\hline TVYY & 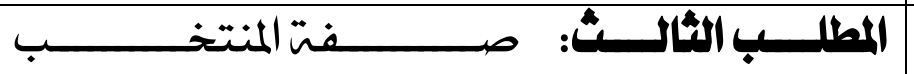 & \\
\hline TVYE & المبحــــث الثالـــث: ترجمــــــة ابـــــن معـــــروف. & 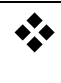 \\
\hline TVT. & بالانتخاب. ت ترجمة مختصرة للإمام الدراقطني وفيها بيـان عنايتهـ & $*$ \\
\hline TVT. & 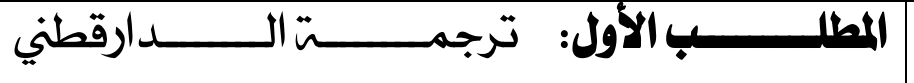 & \\
\hline TVRT & 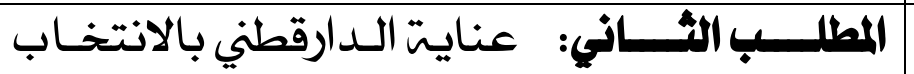 & \\
\hline
\end{tabular}

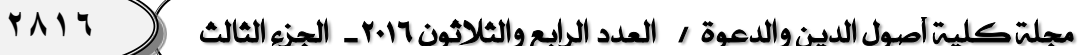




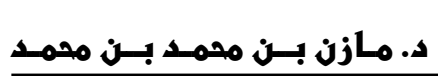

الجزي من الفوائد المنتقاة الغرائب ... تحقيق وتخريج ودراستشنيان

\begin{tabular}{|c|c|c|}
\hline الصفحة & 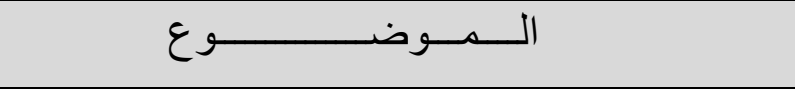 & s \\
\hline YV $\leqslant 1$ & المبحــث الخــامسر: التعريفة بالجزء ووصف & 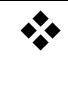 \\
\hline YV $\leqslant 1$ & المطلب الأول: التعريـف بالجزي & \\
\hline rV $\leq 1$ & 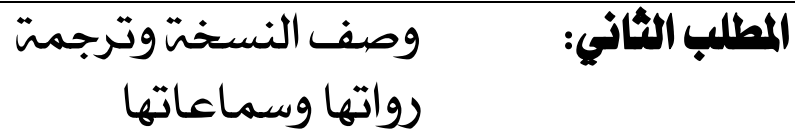 & \\
\hline$r V \leqslant 7$ & نماذج النسخة الخطية & \\
\hline$r V \leqslant V$ & قسم التحقيق & \\
\hline rVq & 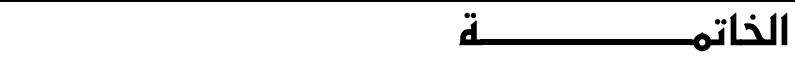 & \\
\hline rVYq & 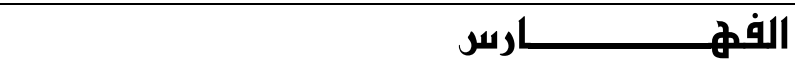 & \\
\hline rVYq & 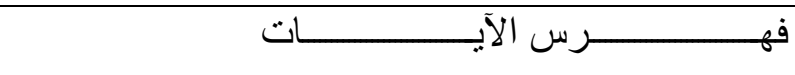 & \\
\hline YVV. & 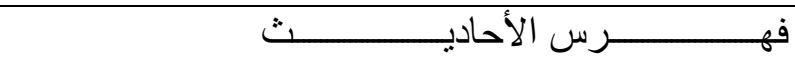 & \\
\hline rVqq & 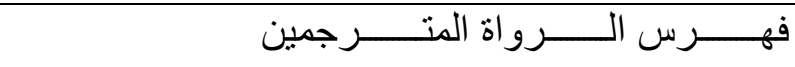 & \\
\hline$r \wedge \cdot 0$ & فهـــــرس المصــــــادر والمر اجــــع & \\
\hline r^I & 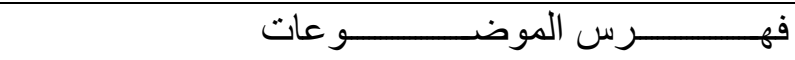 & \\
\hline
\end{tabular}

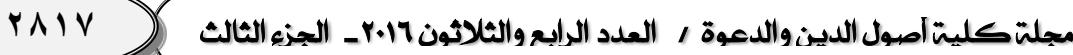




\section{Part of}

\section{Alfawaied almuntagat algharaieb}

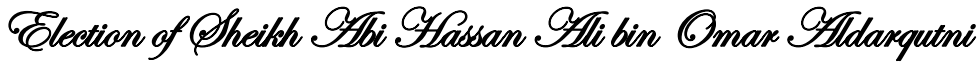

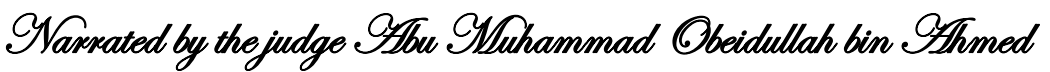

$$
\text { bin MSaaralf }
$$

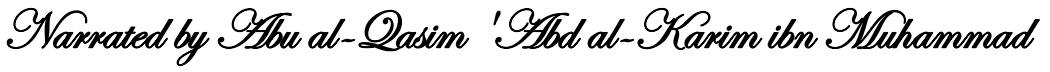
ibn Olbayd Ftlah al-Sayani

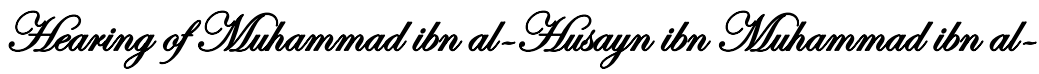

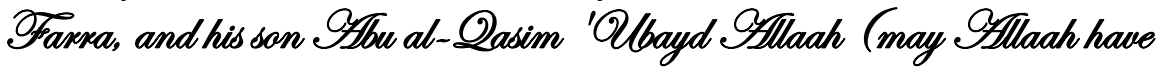
. (mercy on him

Investigation, documentation and study

Investigation, documentation and study

\section{Mazen bin Mohammed bin Mohammed Hassanein}

Atsssciate Professas, QDepastment of the year and its sciences, Qassim Qbniversity

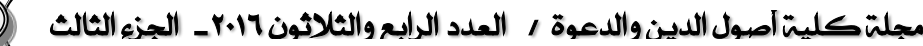

